\title{
FATORES QUE AFETAM O MANEJO INTEGRADO DE Diatraea saccharalis (FABR., 1794) (LEPIDOPTERA: PYRALIDAE) EM CANA-DE-AÇÚCAR
}

FILIBERTO OSCAR TERAN - PEREDO

Orientador: Prof. SINVAL SILVEIRA NETO

Tese apresentada à Escola Superior de Agricultura "Luiz de Queiroz", da Universidade de São Paulo, para obtenção do título de Doutor em Ciências. Área de Concentração: Entomologia.

$P|R A C| C A B A$

Estado de São Paulo - Brasil

Novembro - 1982 
Ao sacrifício e abnegação da MINH $\Lambda$ MAE (in memorian)

A cooperação e dedicação da MINHA ESPOSA

Ao entusiasmo e porvir das MINIIAS FILIIISS, 


\section{AGRADEC IMENTOS}

Um dos problemas ao agradecer a colaboraçio c apoio recebidos neste tipo de estudo tão abrangente ê sele cionar os nomes dos maiores colaboradorcs. Neste caso, sĩo muitas as pessoas que merecem esse agradecimento, porém, a disponibilidade de espaço obriga a cometer algumas províveis injustiças. Assim, o autor expressa seu reconhecimento:

A Copersucar, através da sua dirctoria c das chefias do seu Centro de Tecnologia, especialmente na pessoa do Dr. Wilson Marcelo da Silva, pelo apoio matcrial presta do em todas as fases de elaboração da tese.

Aos colegas e funcionários do Sctor de lintomologia do Centro de Tecnologia Copersucar pela valiosa partí cipação e contribuição nos trabalhos de base.

Aos amigos e colegas das Usinas participantes, por proporcionarem o apoio e recursos necessários para os trabalhos de campo, especialmente oos responsáveis das Us nas Barra Grande, São José ZL, São João, Santa luiza, Santa Adelaide e Santa Cruz S.A.

Aos professores e amigos do Departamento de Entomologia da ESALQ, pelos ensinamentos transmitidos, cspe cialmente ao Dr. Sinval Silveira Neto pela sua comprecnsão e tolerância e ao Dr. Evoneo Berti Filho pelo scu cstímulo.

Aos professores José Roberto P. Parra e Julio Marcos Melges Walder pela ajuda na redação fińal da tesc.

Ao Prof. Dr. Roberto Simionato de Moraes, pe 
la valiosa cooperação e orientação nas anãlises estatístí cas.

A Srta. Célia Regina Scanavaca, pela dedica çao com que executou a datilografia. 


\section{INDICE}

pāgina

1. INTRODUÇAO $\ldots \ldots \ldots \ldots \ldots \ldots \ldots \ldots \ldots \ldots \ldots \ldots \ldots \ldots \ldots \ldots \ldots$

2. REVISAO DE LITERATURA .................. 4

2.1. Literatura estrangeira .............. 4

2.2. Literatura nacional recente ........... 11

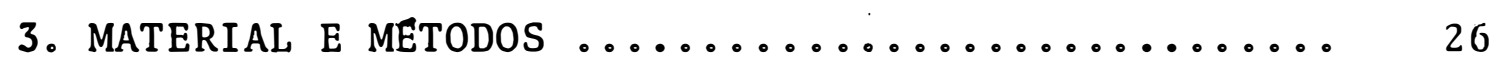

3.1. Idade do canavial .................. 26

3.1.1. Levantamentos de infestação final ... 26

3.1.2. Levantamentos populacionais ....... 27

3.1.3. Testes de controle natural dos ovos

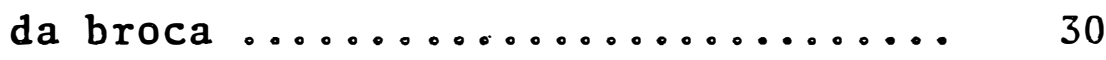

3.1.4. Testes de sobrevivência e duração do ciclo biológico ............... 32

3.1.5. Testes sobre capacidade reprodutiva de 0 . saccharalis .............. 33

3.2. Idade da cana (estado fenológico) ........ 37

3.2.1. Levantamentos de infestação final ... 37

3.2.2. Levantamentos populacionais ...... 37

3.2.3. Testes de controle naturar de ovos da broca $\ldots \ldots \ldots \ldots \ldots \ldots \ldots \ldots \ldots \ldots$

3.2.4. Testes de sobrevivência e duração do

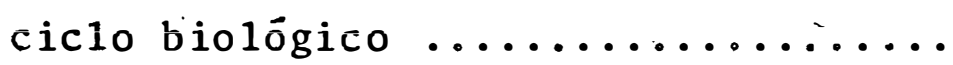

3.3. Variedades de cana ................. 38 
pågina

3.3.1. Levantamentos de infestação fina 1.

3.3.2. Levantamentos populacionais .......

3.3.3. Testes de controle natural de ovos da broca $\ldots \ldots \ldots \ldots \ldots \ldots \ldots$

3.3.4. Testes de sobrevivência e duração do ciclo biológico

3.3.5. Testes sobre capacidade reprodutiva de 0 . sacchanalis

3.4. Estado nutricional da cana ........... 41

3.4.1. Levantamentos de infestação final ..

3.4.2. Levantamentos populacionais .......

3.4.3. Testes de controle natural de ovos

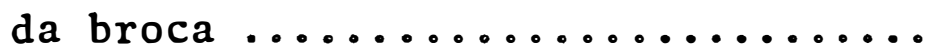

3.4.4. Testes de sobrevivência e duração do

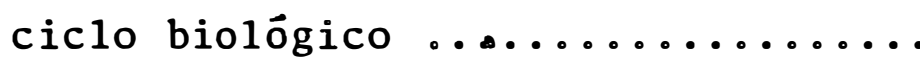

3.4.5. Testes sobre capacidade reprodutiva de 0 . sacchanalis ............. 45

3.5. Efeito da aplicação de vinhaça ......... 46

3.5.1. Levantamentos de infestação final .. 46

3.5.2. Levantamentos populacionais ....... 49

3.5.3. Testes de controle natural de ovos

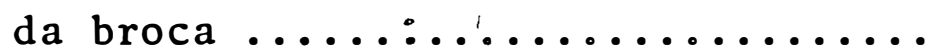

3.5.4. Testes sobre capacidade reprodutiva

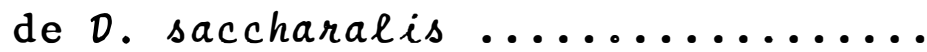


3.6. Anålises estatísticas .............. 49

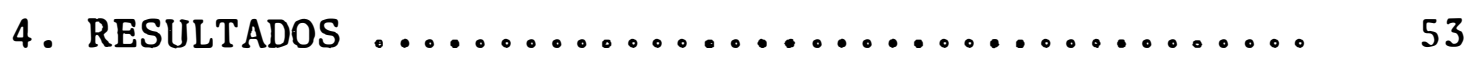

4.1. Idade do canavial ................. 53

4.1.1. Levantamentos de infestação final de 0. saccharalis ................ 53

4.1 .2 . Levantamentos populacionais ....... 54

4.1.3. Testes de controle natural de ovos da broca ..................... 58

4.1.4. Testes de sobrevivência e duração do

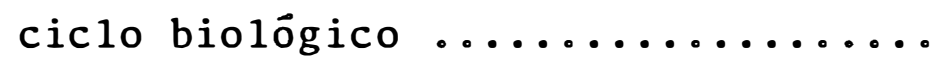

4.1.5. Testes sobre capacidade reprodutiva de 0 . saccharalis ............... 60

4.2. Idade da cana (estado fenológico)........ 62

4.2.1. Levantamentos de infestação final .. 62

4.2.2. Levantamentos populacionais ....... 64

4.2.3. Testes de controle natural de ovos da broca $\ldots \ldots \ldots \ldots \ldots \ldots \ldots \ldots$

4.2.4. Testes de sobrevivência e duração do ciclo biológico ............... 69

4.3. Variedades de cana ................. 69

4.3.1. Levantamentos de infestaçióo final .. 70)

4.3.2. Levantamentos populacionais ....... 74

4.3.3. Testes de controle natural de ovos

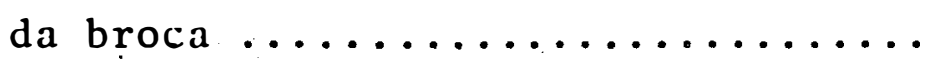


Pảgina

4.3.4. Testes de sobrevivência e duração do ciclo biológico ................

4.3.5. Testes sobre capacidade reprodutiva de 0 . saccharalis ............ 80

4.4. Estado nutricional da cana ........... 81

4.4.1. Levantamentos de infestação final . 81

4.4.2. Levantamentos populacionais ....... 85

4.4.3. Testes de controle natural de ovos

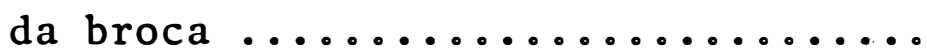

4.4.4. Testes de sobrevivência e duração do ciclo biológico ............... 90

4.4.5. Testes sobre capacidade reprodutiva de 0 . saccharalis ............ 93

4.5. Efeito da ap1icação de vinhaça ......... 95

4.5.1. Levantamentos de infestação final .. 95

4.5.2. Levantamentos populacionais ...... 102

4.5.3. Testes de controle natural de ovos da broca ...................... 104

4.5.4. Testes sobre capacidade reprodutiva de 0 . saccharalis .............. 104

5. DISCUSS

5.1. Idade do canavial ................ 106

5.2. Idade da canà .................. 108

5.3. Variedades de cana ................. 10! 
Pägina

5.4. Estado nutricional da cana $\ldots \ldots \ldots \ldots .6112$

5.5. Efeitos da aplicação de vinha ......... 114

5.6. Observações gerais ................ 116

6. CONCLUSOES ........................ 118

7. LITERATURA CITADA 121

8. APENDICE $\ldots \ldots \ldots \ldots \ldots \ldots \ldots \ldots \ldots \ldots \ldots \ldots \ldots \ldots \ldots \ldots \ldots \ldots \ldots$

Apêndice I 133

Apêndice II ..................... 139 
LISTA DE TABELAS

Pågina

1. Intensidade de.Infestação (I.I.) me̊dia causada pela broca em canaviais de diferentes idades, no Estado de São Paulo. 1977-81 ..........

2. Densidade populacional relativa (coleta por ho ra/homem) e parasitismo da broca em canaviais de diferentes idades, na Usina Barra Grande, SP, em $1981 \ldots \ldots \ldots \ldots \ldots \ldots \ldots \ldots \ldots \ldots \ldots \ldots \ldots \ldots \ldots \ldots \ldots \ldots \ldots$

3. Densidade populacional relativa (coleta por ho ra/homem) e parasitismo da broca em canaviais de diferentes idades na Usina Santa Luiza, SP, en $1981 \ldots \ldots \ldots \ldots \ldots \ldots \ldots \ldots \ldots \ldots \ldots \ldots \ldots$

4. Densidade populacional relativa (coleta por ho $\mathrm{ra} / \mathrm{homem)}$ e parasitismo da broca em canaviais de diferentes idades na Usina Santa Cruz S.A., $S P$, em $1981 \ldots \ldots \ldots \ldots \ldots \ldots \ldots \ldots \ldots \ldots \ldots$

5. Controle natural (induzido) de ovos de 0 . saccharalis em 2 canaviais de diferentes idades, variedade IAC52/150. CTEJ, novembro-dezembro de 1978 .

6. Controle natural (induzido) de ovos de 0 . saccharalis em 2 canaviais de diferentes ida des, variedade NA56-79. Usina Barra Grande, SP. setembro-novembro de $1978 \ldots \ldots \ldots \ldots \ldots \ldots \ldots$ 
7. Sobrevivência de 300 ovos no estāgio "cabcça preta", e duração do período larva + pupa de D. saccharalis, em 2 canaviais da variedade NA56-79, com idades diferentes. Usina Barra Grande, outubro-novembro de $1978 \ldots \ldots \ldots \ldots$

8. Resultados de 8 testes sobre capacidade repro dutiva de $D$. saccharalis, criada em canaviais da variedade NA56-79 com 2 idades diferentes.

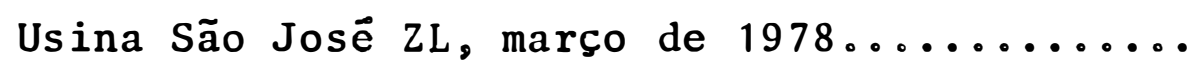

9. Resultados de 2 testes sobre capacidade repro dutiva de $D$. saccharalis, criadas em canaviais pareados da variedade IAC52/150 com idades di ferentes. CTEJ, novembro de $1978 \ldots \ldots \ldots \ldots$......

10. Infestação final pela broca em canas de dife rentes idades de crescimento no momento do cor te ou colheita de 1979, na Usina Barra Grande

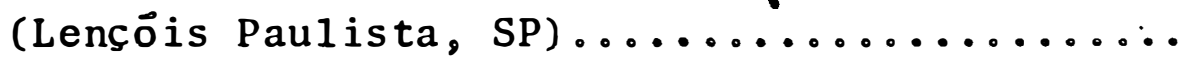

11. Densidade populacional relativa (coleta por ho $\mathrm{ra} / \mathrm{homem}$ ) e parasitismo da broca em canas de diferentes idades de crescimento na Usina Barra Grande, SP, em 1981..................

12. Densidade populacional relativa (coleta por ho $\mathrm{ra} /$ homem) e parasitismo da broca em canas de diferentes idades de crescimento na Usina Santa

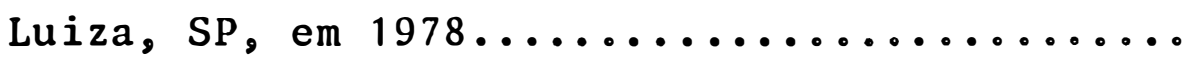


13. Densidade populacional relativa (coleta por ho $\mathrm{ra} /$ homem) e parasitismo da broca cm canas de diferentes idades de crescimento na Usina Santa

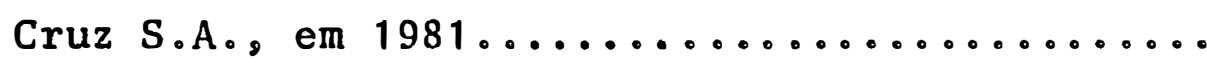

14. Controle natural (induzido) de ovos de $D$. saccharalis em canas com diferentes idudes de crescimento, num canavia1 de 39 corte IAC52/150. CTEJ, maio-julho de $1978 \ldots \ldots \ldots \ldots \ldots \ldots$

15. Controle natural (induzido) de ovos de $D$. saccharalis em canas com diferentes idades de crescimento, num canavial de 29 corte CB41-76. Usina Barra Grande, outubro de 1978.........

16. Sobrevivência de 180 larvas recém eclodidas, e duração do período 1arva + pupa de 0 . saccharalis, em canas com diferentes idades de crescimento, CB41-76, soca. Usina Barra Grande, 1977-78....

17. Médias de Intensidade de Infestação (I.I.) por D. saccharalis em variedades de canas amostra das em 1978, comparadas pelo teste Tukey e pelo intervalo de confiança da mëdia a $5 \%$ de probabi

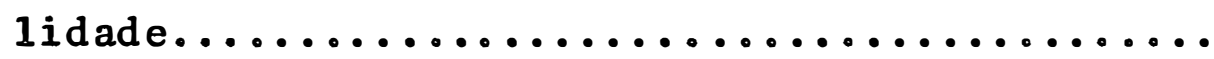

18. Médias de Intensidade de Infestação (I.I.) por D. saccharalis em variedades de cana, amostra das em 1980, comparadas pelo teste de Tukey e pelo intervalo de confiança da média a $5 \% . .$. . 
19. Mëdias de Intensidade de Infestação (I.I.) por D. saccharalis em variedades de cana, amostra das em 1981, comparadas pelo teste de Tukey e pelo intervalo de confiança da mëdia a $5 \% . . .$.

20. Infestação final causada pela broca em 4 varie dades de cana planta, amostrando 100 canas por variedade. CTEJ, $1979 \ldots \ldots \ldots \ldots \ldots \ldots \ldots \ldots$

21. Densidade populacional relativa (coleta por hora/ho mem) e parasitismo da broca em seis variedades de cana na Usina Barra Grande, SP, em 1981....

22. Densidade populacional relativa (coleta por ho ra/homem) e parasitismo da broca em três varie dades de cana, na Usina Santa Luiza, SP, cm 1981.

23. Densidade populacional realtiva (coleta por ho $\mathrm{ra} /$ homem) e parasitismo da broca em nove varie dades de cana, na Usina Santa Cruz S.A., SP, em

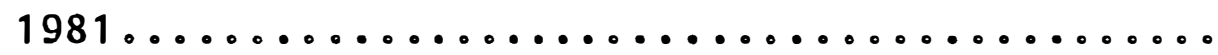

24. Densidade populacional relativa (coleta por ho ra/homem) e parasitismo da broca em 4 varieda des de cana de primeiro corte, e da mesma idade de crescimento. CTEJ, janeiro-fevereiro de 1979.

25. Controle natural (induzido) de ovos de 0 . saccharalis em 4 variedades de cana de primeiro corte. CTEJ, setembro/78 a junho/79......... 
26. Sobrevivência e duração do periodo larva + pupa de 0 . saccharalis, em 2 variedades de cana. Te lado da CTES, $21 / 11 / 78$ a $11 / 10 / 79 \ldots \ldots \ldots \ldots$

27. Sobrevivência e duração do período larva + pupa de 0 . saccharalis, em 2 variedades de cana. Usi na Barra Grande, SP. outubro/77 a junho/78....

28. Sobrevivência de 875 ovos "cabeça preta", e dü ração do periodo larva + pupa de 0 . saccharalis, em 4 variedades de cana.CTEJ, setembro/78 a $\operatorname{marcco} / 79 \ldots \ldots \ldots \ldots \ldots \ldots \ldots \ldots \ldots \ldots$

29. Resultados de 6 testes sobre capacidade reprodu tiva de 0 . saccharalis, criadas em 4 variedades de cana de primeiro corte. CTEJ, janeiro-março/

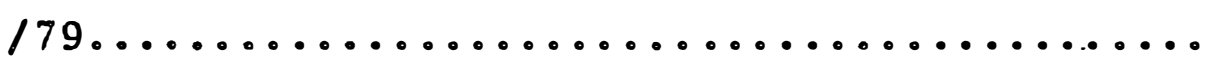

30. Infestação final da cana pela broca em experi mentos de adubação nas Usinas São Geraldo e San ta Luiza, SP. Médias de 60 canas examinadas,

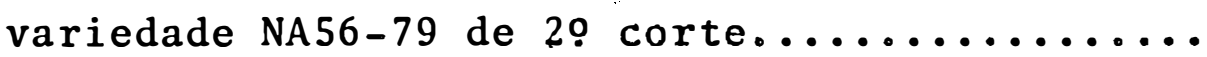

31. Infestação final pela broca, em cana IAC52/150 de 1 e corte adubada diferencialmente, em amos tras de 100 canas por tratamento. Usina São Josê $\mathrm{ZL}, \mathrm{SP}, 1978 \ldots \ldots \ldots \ldots \ldots \ldots \ldots \ldots \ldots$

32. Infestação final pela broca, em cana planta NA56-79 adubada diferencialmente, em amostras de 200 canas por tratamento. Usina São José ZL,

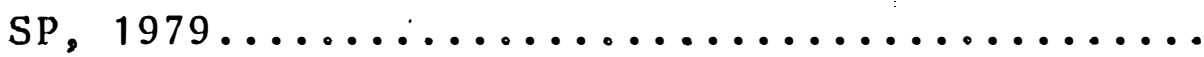


33. Densidade populacional (coleta por ha) e parasi tismo da broca em cana NA56-79 plantada com adu bações diferenciadas na Usina São Josē ZL, SP.

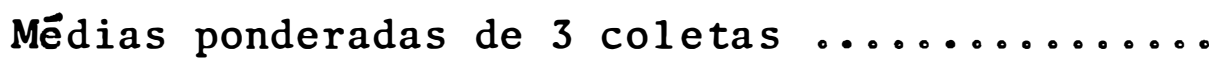

34. Densidade populacional da broca por ha, em cana planta NA56-79, sujeita a adubações diferencia das. Levantamentos efetuados em 3 etapas de crescimento da cana, na Fazenda Patos da Usina

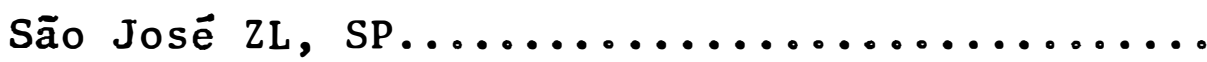

35. Parasitismo $\left(\frac{0}{0}\right)$ da broca por moscas taquinídeas (M. minense e $P$. claripalpis) em cana planta NA56-79, sujeita a adubações diferenciadas. Le vantamentos efetuados em 3 etapas de crescimen to da cana. Fazenda Patos da Usina São José ZL,

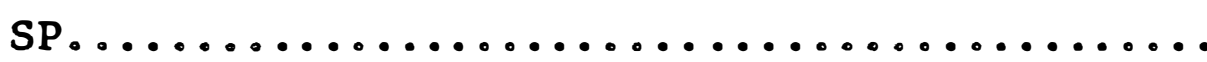

36. Controle natural (induzido) de ovos de $D$. saccharalis em 2 canaviais plantados, em solos de diferentes fertilidades com a variedade NA56-79. Usina São Josẽ ZL, SP, Março de 1978..

37. Controle natural (induzido) de ovos de $D$. saccharalis, em cana planta IAC52/150 adubada diferencialmente, na Fazenda Sto. Antonio da Usina São Josẽ $\mathrm{ZL}, \mathrm{SP} \ldots \ldots \ldots \ldots \ldots \ldots \ldots \ldots \ldots$

38. Controle natural (induzido) dé ovos de $D$. saccharalis, em cana planta NA56-79 adubada di ferencialmente, na Fazenda Patos da Usina São José $Z L, S P . \ldots \ldots \ldots \ldots \ldots \ldots \ldots \ldots \ldots \ldots$ 
39. Sobrevivência de 180 larvas recém eclodiclas, e duração do período larva + pupa de 0 . saccharalis, em cana IAC52/150, adubada dife rencialmente na Fazenda Santo Antonio da Usina São José $Z L, S P$. Nov.-Dez./77 ..........

40. Sobrevivência de 600 larvas recém eclodidas, e duração do período larva + pupa de 0 . saccharalis, em cana planta NA56-79, adubada diferencialmen te na Fazenda Patos da Usina São José ZL, SP,

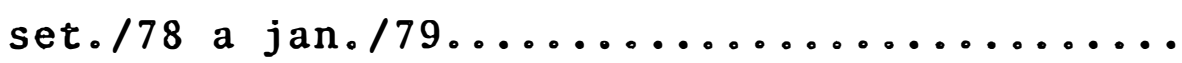

41. Sobrevivência de 500 larvas recém eclodidas, e duração do período larva + pupa de 0 . sacchanalis, em cana soca IAC52/150, adubada diferencialmen te, na Fazenda Santo Antonio da Usina São José ZL, out./78 a jan./79................

42. Sobrevivência e duração do período larva + pu pa de 0 . saccharalis, em cana planta e soca CB41-76 adubada diferencialmente, no telado da CTES. nov./78 a out./79 ...............

43. Resultados de 3 testes sobre capacidade repro dutiva de 0 . saccharalis, criadas em cana plan ta IAC52/150 adubada diferencialmente, na Fa zenda Santo Antonio da Usina São José ZI,, SP. fev.-mar. $/ 78 \ldots \ldots \ldots \ldots \ldots \ldots \ldots \ldots \ldots \ldots \ldots \ldots \ldots \ldots$

44. Resultados de testes sobre capacidade reprodu tiva de 0 . saccharalis, criada em cana de 1 9 corte NA56-79, plantada em 2 solos de diferen 
Păgina

tes fertilidades, na Usina São José ZL, SP.

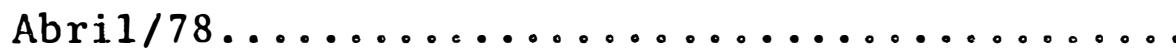

45. Resultados de testes sobre capacidade reprodu tiva de 0 . saccharalis, criada em cana planta NA56-79, adubada diferencialmente na Fazenda Patos da Usina São José ZL, SP. dez.78 a fev./ /79.............................

46. Infestação final da cana pela broca, comparan do canaviais irrigados com vinhaça diluída (por infiltração) e canaviais não irrigados na Usi na São João, SP, 1976-78..............

47. Infestação final da cana pela broca em 2 experimentos de vinhaça e adubação, em cana NA56-79 soca (Usina Santa Adelaide, SP) e cana CB41-76 ressoca (Usina São Carlos, SP). Média de 90 ca nas examjnadas, $1978 \ldots \ldots \ldots \ldots \ldots \ldots \ldots$

48. Infestação final pela broca em experimentos de vinhaça aplicada em cana CB41-76 de 19 corte (aplicação única), e de 49 corte (aplicação acumulada), na Usina São Carlos, SP. Médias de 150 canas examinadas por tratamento. 1979....

49. Infestação final causada pela broca em cana ix rigada (por 2 anos) com vinhaça comparada a uma testemunha, em 200 canas amostradas por tra tamento, Cana NA56-79 de 39 corte. Usina Barra

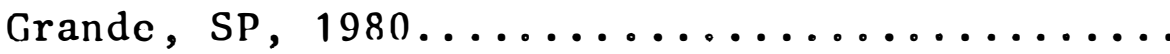


50. Densidade populacional relativa da broca (coleta por hora/homem) em cana NA56-79 de 39 corte, com e sem irrigação de vinhaça. Usina Barra Grande, SP, 1970-80................... 103

51. Parasitismo $\left(\begin{array}{l}0 \\ 0\end{array}\right)$ de brocas coletadas em cana NA56-79 de 3! corte, com e sem irrigação de vi nhaça. Usina Barra Grande, SP, 1979-80....... 103

52. Controle natural (induzido) de ovos de 0 . saccharalis, em cana NA56-79 de 30 corte, com e sem irrigação de vinhaça. Usina Barra Grande, SP, out./79 a jun./80................... 104

53. Resultados dos 13 testes sobre capacidade repro dutiva de $D$. saccharalis, criada em canaviais com e sem irrigação de vinhaça na Usina Barra Grande, SP. Fevereiro-Março/80........... 
LISTA DE FIGURAS

Pågina

1. Modelo de formulärio utilizado nos levantamentos

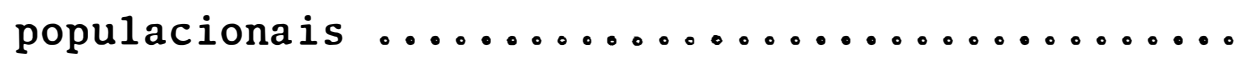

2. Modelo de formulärio utilizado nos testes de con trole natural de ovos da broca .............

3. Modelo de formulärio utilizado nos testes de so brevivência e duração do ciclo biológico .......

4. Modelo de formulärio utilizado nos testes sobre capacidade reprodutiva dos adultos da broca ....

5. Correlação entre idade do canavial (corte) e in festação pela broca. 1977 a $1981 \ldots \ldots \ldots \ldots \ldots \ldots$

6. Relação entre idade do canavial e densidade popu lacional da broca, em 3 Usinas do Estado de São Paulo, $1981 \ldots \ldots \ldots \ldots \ldots \ldots \ldots \ldots \ldots \ldots \ldots$

7. Relação entre idade do canavial e parasitismo to tal na broca, em 3 Usinas do Estado de São Paulo, 1981

8. Correlação entre infestação final pela broca e idade da cana no momento da colheita. Usina Barra

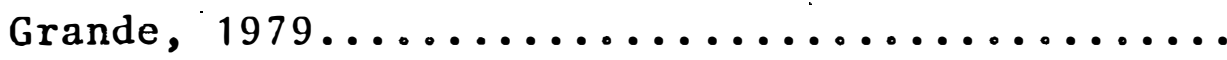

9. Relação entre idade da cana e densidade popula cional da broca, em 3 Usinas do Estado de São

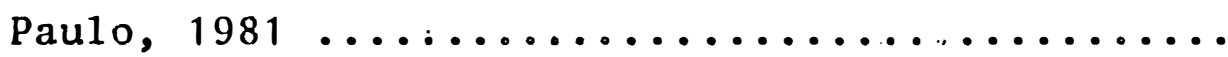


10. Relação entre idade da cana e parasitismo total na broca, em 3 Usinas do Estado de São Paulo, 1981

11. Relação entre adubação da cana e infestação pe la broca em cana soca NA56-79. Usinas São Gera1 do e Santa Luiza, SP, 1978................

12. Efeito da aplicação de vinhaça diluida, por in filtração, sobre a infestação final da cana pe la broca, em canaviais comerciais da Usina São João, SP..........................

13. Relação entre dose de vinhaça aplicada na cana, com e sem complementação mineral NP, e sua in festação final pela broca...............

14. Efeito da aplicação ünica e acumulada de vinha ça (em doses crescentes) na infestação da cana pela broca. Usina Säo Carlos, SP. 1979........ 
FATORES QUE AFETAM O MANEJO INTEGRADO DE Diatraea sacchirap is (FABR , 1794) (LEPIDOPTERA： PYRALIDAE) EM CANA-DE-AÇOCAR

Orientador: Prof. Sinval Silveira Neto

Candidato : Engọ Agrọ Filiberto Oscar Terān-Peredo

RESUMO

O trabalho objetivou identificar alguns lat $\underline{\text { o }}$ res do hospedeiro que governam as variações na infestaçio de D. saccharalis em canaviais comerciais do Estado de São l'au 1o e, portanto, responsáveis pelos desequilíbrios populacio nais que causam grandes danos e perdas à cana.

Efetuaram-se levantamentos de infestação final (danos à cana determinados no momento da colheita) nos cuna viais comerciais de Usinas de 1977 a 1981. Durante 1981 fo ram efetuados tambëm extensos levantamentos populaciona is (da broca e seus parasitos larvais) em canaviais das Usinas Barra Grande (Lençóis Paulista), Santa Lưiza (Matão) e Santa cruz S.A. (Capivari).

Visando descobrir as causas ou mecanismos das diferenças de infestação, foram efetuados os seguintes tes tes controlados: a) testes de controle natural de ovos da broca, expondo estes à ação de parasitos e predadores nos ca naviais diferenciados; b) testes de sobrevivência e duração do ciclo biológico, "inoculando-se" artificialmente tollce ras isoladas nos canaviais diferenciados c acompanhando-se a evolução populacional da praga; ${ }^{\circ}$ ) testes sobre capacidade reprodutiva, utilizando-se adultos criados cm canaviais dile 
renciados, para determinar a sua fecundidade e fertilidadc.

A anālise global dos resultados discutidos nes te estudo mostram que:

- A idade do canavia1, isto é, o "envelhecimento" da cultura, tem marcada influência na infestação final pela broca. A principal causa da redução de infestação ê a diminuiçĩo da capacidade reprodutiva da broca nos canaviais mais velhos, auxiliada pelo maior controle natural dos ovos.

- A idade da cana no momento da colheita, isto è: o tempo de vegetação da cana, influi na infestação final causada pela broca, sendo esta maior quanto maior o período vegetativo da cana. A provāvel causa deste aumento é o acủmulo de ge raçōes da broca nos períodos vegetativos mais prolongados.

- Apesar das variações na "suscetibilidade" ou "resistência" das variedades de cana existe uma clara tendência de algu mas serem sempre mais infestadas, pela broca, como CP51-22, NA56-79, IAC52/150, IAC51/205 e IAC58/480, enquanto que outras mostram sempre menores infestações como. Co740, IAC50/134, CB47-355, IAC48/65, CB49-62 e Co775. As causas destas diferenças não estão suficientemente explicadas.

- Existe clara influência do estado nutricional da cana so bre a infestação final causada pela broca. Cana adubada permite maior infestação, a qual aumenta com doses crescen tes de potāssio e nitrogênio, faltando definir a influcen cia da interação destes e de outros nutricntes. A princi pal causa dos aumentos de infestação é o aumento da capaci dade reprodutiva da broca, criada nesses canaviais aduba dos. Alguns micronutrientes influem nesta infestação, nota damente $o \mathrm{Zn}$ que interfere na fertilidade da broca. 
A vinhaça aplicada nos canaviais (especialmente em socue i ras) aumenta a infestação final causada pela broca, sencló esta maior com doses crescentes ou acumuladas de vinhaca. Ocorre na realidade uma interação de irrigação e nutrição. A vinhaça e adubação de soqueiras modificam a tendência de redução de infestação causada pela broca com o avanço da idade do canavial. 
FACTORS-AFFECTING INTEGRATED MANAGEMENT OF Diatraca saccharalis (FABR。, 1794) (LEPIDOPTERA: PYRALIDAE) IN SUGARCANE

Adviser: Prof. Sinval Silveira Neto

Candidate: Eng $\stackrel{\circ}{\circ}$ Agrọ Filiberto Oscar Terän-Peredo

SUMMARY

The purpose of this work was to identifty some host factors that govern infestations of $D$. saccharalis in commercial cane fields of the State of São Paulo, hence responsible for unbalanced borer populations causing inuch damage and losses to cane.

"Final" infestation surveys (damage caused to cane as determined at harvesting) were carried out in commercial cane fields of sugar factories from 1977 to 1981. Population surveys (of the borer and its larval parasites) were also carried out during 1981 in cane fields of Barra Grande (Lençōis Paulista), Santa Luíza (Matão) and Santa Cruz S.A. (Capivari) mills.

Looking for the causes or mechanisms of dif ferential infestations the following tests were run: tests on natural control of borer eggs by exposing them to parasites and predators in differentiated cane fields;

tests on survival and 1 ife span of borers by artificial "inoculation" of isolated cane stools in differentiated cane fields and following the late of them; c) tests on reproduc tive capacity of adults reared from differentiated cane fields in order to determine their fecundity and fertility.

The overall analisis of discussed results of 
this study shows:

- The age of cane field, that is: ageing of the crop, has marked influence on infestation by borers. The main caluse of these decreased infestations is the lower reproductive capacity of borers in ratoon canes, and the higher natural control of borer eggs in these old cane fields.

- The age of cane plant at harvesting; that is: vegetative period of cane, influences markedly borer infestations showing higher infestations in prolongued vegetative periods. Accumulation of borer generations during these long vegetative periods is probably tha main cause of this increased infestation.

- In spite of variations as regards susceptibility or resistance of cane varieties, there is a clear tendency of some varieties to show infestations always above the average such as CP51-22, NA56-79, IAC52/150, IAC51/205 and IAC58/480, while others show infestations always below the average such as Co740, IAC50/134, CB47-355, IAC48/65, CB 49-62 and Co775. The causes of these differences are not sufficiently explained.

- There is a clear influence of cane nutrition on final infestation caused by the borer. Fertilized canes develop higher infestations, showing a trend to increase with increased dosage of potash and nitrogen, while there is no clear influence of the interaction of these and other canc nutrients. The higher reproductive capacity of horcrs reared on those fertilized cane is reponsible for these increases of infestation. Some minor nutrients also alfect infestations, specially $\mathrm{Zinc}$ that interferes on borer fertility. 
- "Vinasse" (1iquid residue of alcohol destilation) applica on cane fields (specially ratoons) increases borer infes tations, being higher at higher doses or accumulated applications. The effect is a combination of irrigation and cane nutrition. Vinasse and fertilization of ratoon canes modify the normal tendency of reduced infestations in older ratoons. 


\section{INTRODUÇÃO}

Seria, talvez, repetitivo e desnecessírio aprofundar-se em maiores exposições ou detalhes sobre a ne cessidade de se controlar a broca da cana Diatraca saccharalis, porque já foi definida por vários autores c instituições, a importância econômica deste inseto como praga das culturas de cana no Estado de São Paulo e no Brasil todo, não só pelos danos diretos que ocasiona, mas também pelos danos inclire tos, ao abrir pontos de entrada para as podridões, ocasio nando assim, perdas que justificam todo esforço para dimi nuir seus danos.

Por outro 1ado, não foge ao conhecimento ge ra1, a importância econômica das culturas da cana, não số para o Estado de São Paulo, que participa com quase $50 \%$ da produção brasileira, como para o Brasil, que è o maior pro dutor de açúcar e ālcool de cana no mundo atual.

A preocupação é tal que, as principais inst tuições ligadas à indústria açucareira-alcooleira, como Copersucar e Planalsucar, além das Universidadís fnotadimen te a Escola Superior de Agricultura "Luiz de Queiroz" da U.S.P.), o Instituto Agronômico de Campinass. o Instituto 
Biológico de São Paulo, o Centro de Energeia Nuclear da Agricultura, etc., estão encaminhanclo seus esforços para com bater esta praga, pelos diversos métodos conhecidos, desta cando-se o Controle Biológico, por diversas razões que jus tificam essa prioridade (TERÃN, 1976).

No entanto, este controle deve ser enfociado face aos chamados "novos" conceitos ou filosofias, isto e: do "manejo de pragas". e do "controle integrado" que ultima mente se aglutinaram no conceito generalizado de "mancjo integrado de pragas".

Este conceito, que está sendo explorado ammpl li menté nos ûltimos anos, ẻ uma consequência lógica dos pró gressos obtidos no controle de pragas, ou mesmo uma evolü ção das experiências anteriores. Pode-se ainda dizer que esta evolução talvez seja o retorno a princípios filosóf cos de povos nativos ou civilizações primitivas avançalas mas com um arsenal de metodologias e recursos têcnico-cicn tificos, que facilitam grandemente o trabalho atual.

Esta filosofia estratégica, confirmada inclu sive através da sigla IPM ("Integrated Pest Managcment") es t $\vec{a}$ baseada fundamentalmente em princípios ccológicos. lista base ecológica é de tal importância que o IPM foi tambëm chanado de "ecologia aplicada" ou "estratégia de controle de pragas baseado ecologicamente" (FLINT e BOSCH, 1981).

No caso da Diatraea saccharalis o conhecimen to acumulado, è bastante volumoso mas quasc todo material bibliogräfico refere-se a pesquisas isoladas. Portanto, e necessärio ordenar e organizar todos esses confice imentes, pal ra postular um esquema de manejo deste inseto-praga nas cul turas de cana, procurando integrar os diversos conhecimen 
cos, tanto de praga, como do seu hospedeiro em consideraç̃o (cana).

Visando essa integração de conhecimentos, ten tar-se-ão identificar alguns desses fatores ccológicos cha ves que governam as flutuações das populações locais da D. saccharalis nos canaviais e, portanto, responsáveis por esses desequilibrios populacionais, que causam as altas in festações à cana. 


\section{REVISÃO DE LITERATURA}

$\mathrm{Na}$ quase impossibilidade de se revisar toclos os trabalhos sobre ecologia e controle da broca da cana-de-açúcar, a revisão foi reduzida às publicações mais relacio nadas, tanto no exterior como no Brasil.

\subsection{Literatura estrangeira}

$\mathrm{Na}$ procura das primeiras tentativas de contro 1e de 0 . sacchanalis voltanse até o século passado, quan do, em Cuba e outras partes da região Neotropical foram efe tuadas vārias destas tentativas, segundo consta nas inúme ras publicações de princípios deste século, por conhccidos autores como Plank, Myers, Tucker, Van Dyne, Cleare, Jaynes, Box, Wolcott, etc.

Dentro dessa profícua produção literāria so bre alguns métodos de controle no início deste século, des taca-sc a revisĩo de HOLLOWY et alie (1928) que além de reunir valiosos dados descritivos e bioccológicos, apresen ta uma excelente relação de fatores de controle "natural" des: te inseto, nos Estados Unidos. A publicação é complctida com uma relação dos diversos métodos de controlc "artificiall", 
que abrangem medidas de controle cultural, biológico e quí mico.

BOX (1926) ofereceu outra contribuição impor tante na época para a Guiana Inglesa. Nesta publicação sc faz uma descrição bastante ütil e' interessantc clos fatores que influem na prevalência de värias espécies de Diatraca, agrupando-os entre artificiais (situaçõcs c variaçõcs da mesma cultura da cana) e naturais (condições metcorológicias e incidência dos inimigos naturais), dando uma maior aten ção aos inimigos naturais.

0 mesmo autor (BOX, 1947), posteriormente en riqueceu estas informações e considerações para a Venczucla apresentando, provavelmente, a relação mais completa da sua profunda experiência com estes insetos, feita antes do seu afastamento da ativa. Os conceitos básicos deste autor ro ram repetidos muitas vezes pelos demais autores, que escre veram posteriormente sobre controle biológico de Diatraca. Estas contribuições, embora não ilustradas quantititiva mente, são o enfoque mais racional de controlc destes in setos para a Região Neotropical, não só pelo enfoque cminen temente ecológico, mas tambēm pela proposta integração de uma série de medidas para o manejo das populações deste in seto nos canaviais. A publicação contém uma intcressante dis cussão sobre as plantas hospedeiras e ecologia, seguida de uma exposição dos fatores que influem na abundância de Diatraea, agrupando-os em climảticos, biológicos c agríco 1as. Referem-se estes ûltimos, às variações da cultura da cana e sua influência nas infestaçõcs da praga, Completa o trabalho uma relação e descrição dos vários inimigos natü rais da broca, abrangendo os predadores c organiismos paras $\underline{i}$ ticos (de ovos, larvas e pupas da broca), apresentando um verdadeiro catảlogo de parasitos de Diatrae $a$ ? Finalmente 
efetuou uma discussão dos métodos de controle agrupando estes em artificial e biológico e, embora reconhecendo que este último oferece a solução mais pronta e prática, aler tou sobre a necessidade de maiores conhecimentos ecológicos, para uma melhor utilização do controle biológico.

Desde princípios deste sêculo, a maioria dos autores seguiu a linha de controle biológico, procuranclo in migos naturais, especialmente parasitos, nas diversas re giões açucareiras da América, para tentar introduzí-los e colonizâ-1os em outras äreas. Destacam-se nesta linha dc ação vârios entomologistas britânicos, cujos trabalhos estĩo quase. todos citados pelo mesmo BOX (1947), e completiados por BENNETT (1969) no que se refere aos esforços com os taquinídeos.

Alguns desses esforços foram aparentemente bem sucedidos, especialmente nas ilhas do Caribe, como relatam SIMMONDS (1955, 1959) e MISKIMEN (1962). Em outros casos, c $\underline{s}$ tes esforços tiveram que se prolongar por muitos anos até conseguir sucesso, como aconteceu, em Barbados (AIAM et alii, 1971)."Em alguns países, a introdução e consequente colon zação de parasitos, nem sempre resolveu o problema das a tas infestações causadas pela broca, como em Porto Rico (MARTORELL e MEDINA, 1965), ou na Louisiana e F1óricla (CHARPENTIER et alii, 1971). Nestes ü1timos Estados, todas as tentativas efetuadas para colonizar os diversos agentes biolóĝicos (parasitos, predadores e pạtógenos), só resultạ ram no estabelecimento definitivo de 5 das 56 espécics in troduzidas.

Outro grupo de entomologistas, na maioria la tino-americanos, seguindo uma linha um pouco'diferente de 
controle biolögico, partiu para liberações suplementares de taquinídeos nativos, criados nas mesmas brocas coletadas do campo. O sucesso destes trabalhos iniciados em Cuba com a Lixophaga diatraeae (SCARAMUZZA, 1946), continuou no peru com a Paratheresia claripalpis, Wulp (RISCO, 1954),

na Venezuela com a Metagonistylum minense Townsend (CUAGllluml, 1962) e na Colômbia com as duas ültimas e Jayneslestia jayanesi (RAIGOSA, 1976).

No Brasil, SoUzA (1942) mostrou que tanto $M$. minense como Paratheresia brasiliensis, poderiam ser criadas em laboratório com relativa facilidade, e sugeriu a criacio artificial desses parasitos, para sua distribuição nos ca naviais de Campos, Rio de Janeiro, porêm salientando tambēm a importância de inimigos naturais exóticos. Tm São Palulo, GALLO (1952) conseguiu também criar tanto $M$. minense como L. diatraeae, relatando resultados positivos de controle da broca com liberações destes parasitos, recomendando a sua criação sistemātica em larga escala e sua distribuição pe riódica nas culturas de cana, a fim de anular o efeito do hiperparasitismo.

Por outro lado, alguns entomologistas

na Louisiana partiram para a linha de controle químico, moti vados aparentemente pelo fracasso das introduções de inimi gos naturais e pelos sucessos espetaculares na época com o uso de inseticidas na agricultura. Este movimento pode ser visualizado através de resultados positivos como os relata dos por ELLISOR e INGRAM (1939), DUGAS (1956), LUNG; et alii (1959) e HENSLEY et alii (1968). Uma relação destas e outras experiências, procurando sempre melhores resulta dos econômicos e fugindo dos problemas causados pela resis tência da broca aos inseticidas, estão resumidos no livro sobre Pragas da Cana-de-Açūcar ("Pests of Sügarcanc"), cdi 
tado por WILIIAMS et alii (1969). Este 1 ivro resume também alguns conhecimentos ecológicos sobre a broca e quase tudo sobre as medidas de seu controle. Fazem parte do 1 ivro capí tulos dedicados ao uso de inseticidas contra a broca, uso de präticas culturais, uso de parasitos de ovos (Trichogramma spp), utilização de resistência varietal da cana e utiliza ção de taquinídeos para o controle desta prasa. Porém, nĩo se percebe nenhum enfoque de integração desses métodos do controle.

Apōs essas revisões, surge uma interessante proposta de HENSLEY (1971 a, 1971 b) para o manejo das popul lações da broca na Louisiana, baseada na utilização de insc ticidas. A modificação mais importante $\vec{e}$ a redução do númc ro de aplicações de inseticidas a 2 ou 3 por temporada, apoia da pela utilização de técnicas melhoradas, que assinalam no campo a real necessidade de se aplicar os inseticidas, alím da utilização de variedades de canas mais resistentes. Es te manejo é orientado ecologicamente e visa a proteção dos inimigos naturais, especialmente predadores, que ja tinham se mostrado como os principais fatores de controle natural nas condições de Louisiana (NEGM e HENSLEY, 1971). Este tra balho foi tão bem aceito, que atê serviu como exemplo prít co do manejo de pragas para SOLOMON (1973).

Numa posterior revisão sobre pragas da cani-de-açücar, LONG e HENSLEY (1972) fizeram comentários críti cos dos diversos mëtodos de controle da broca, agrupando-os em controle biológico, controle cultural, resistência do hospedeiro, controle com inseticidas, terminando com uma revisão sobre possibilidades dos atraentes scxua is como meios de controle. No controle biológico, faz-se um resumo critico das tentativas de controle com os parasitos de ovos Trichogramma spp, mostrando que não se conseguiram succsios 
no campo, apesar dos intensos programas, especialmente na. Louisiana e em Barbados.

A têcnica de esterilização das populações da broca não deu ainda resultados positivos e prăticos. Exis tem só resultados parciais conseguidos com populações de 1aboratório, tanto em Porto Rico (WALKER et alii, 1971), como na Louisiana (SANFORD, 1976). A possibilidade de se integrar este método com liberações estratégicas de Lixophaga diatraeae foi analisada teoricamente e recomenda da por KNIPLING (1972).

0 grande interesse atual, nos Estados Unidos, para substituir os inseticidas por outros meios de contro 1e e a recomendação de KNIPLING (1972) motivaram recentes esforços que se realizaram na Louisiana e na flórida para avaliar as possibilidades de $L$. diatraeae para controlc da broca. Aparentemente, liberações maciças na Louisiana (mais de 1.000 moscas por ha) não deram resultados satisfa tōrios (PHERSON E HENSLEY, 1976), apesar da eficiência de L. diatraeae em localizar e parasitar seu hospedeiro e da sua alta mobilidade e dispersão; fato recentemente confir mado por KING et alii (1981). No entanto, na Flórida, os resultados foram mais positivos (SUMMERS et alii, 1976).

$$
\text { o enfoque ecológico de HENSLEY (1971 a, b) }
$$
foi reafirmado na recente revisão de REAGAN (1981) sobre manejo integrado de pragas da cana para Louisiana, indican do que o sistema foi desenvolvido em resposta ao uso pesa do de inseticidas, aos transtornos ecológicos causados pe los pesticidas, e aos fracassos de controlc por causa di resistência da praga-chave: Diatraea saccharalis. Destaca -se que as aplicações anuais de inseticidas por canavial foram reduzidas de 12 para 2 desde 1960, devido principal 
mente ao monitoramento efetuado atualmente por consultores privados que resulta em uso correto e apropriado de inscti cidas seletivos, além do uso de variedades de cana resis tentes e da proteção de artrōpodos benéficos, principal mente dos predadores nativos. Este trabalho também relata resultados mostrando que em canaviais não tratados, os predadores eliminam $24 \%$ das brocas em cana-planta, 36, 50 na soqueira, e $58,5^{\circ}$ na ressoca.

Na F1órida, RICE (1981) relatou resultados positivos de controle em canaviais comerciais, integrando um sistema de monitoramento com a aplicação seletiva de in seticidas, protegendo assim o complexo de inimigos nat rais da broca, especialmente as vespas Apanteles e Agathis, concluindo que os dados mostram o sucesso do programa de monitoramento para o controle da broca, pela utilização dos parasitós e predadores presentes e pela aplicação selctiva de inseticidas.

Em Barbados, após o sucesso inicial no con trole da broca com os dois parasitos introduzidos, ALAM (1980) fez uma reavaliação dos fatores biológicos e ecoló gicos que afetam as populações da broca, concluindo que os dois parasitos trouxeram uma redução aproximada de $10 \%$ de entrenós broqueados, enquanto que as mudanças varictais da cana foram responsáveis por um aumento de $1-1,5^{\circ}$ de en trenós broqueados desde 1974. Por outro 1ado, afirmou que a "queimada" prē-colheita pode ter reduzido de 1,5 a $2 \%$ de entrenós broqueados neste mesmo período. Diz tambẻm que este fator ecológico (queimada) permite um räpido cresci mento da broca com um pobre controle inicial pelos paras $\underline{\mathbf{i}}$ tos mas que a anâlise global das mudanças pöpulacioniı durante longos períodos de não queimada e posterior perío do de queimada pré-colheita, mostram-se currelacionilos 
com uma redução adicional de entrenós broqueados.

\subsection{Literatura nacional recente}

Com a expansão da indústria açucareira-alcoo leira no Brasil, renovou-se o interessc de controlar a bro ca nos canaviais, e a plublicação de GUAGLIUMI (1973), vcm resumir os conhecimentos bioecológicos sobre este inscto e sobre seu controle para o Nordeste do Brasil, até cssa época. Paralelamente, no Centro-sul brasileiro, surgiu uma verdadeira produção de publicações sobre este tema.

A preocupação oficial da indústria açucarci ra-alcooleira com a broca está claramente expressa nos rẹ latórios anuais publicados pelo PLANALSUCAR de 1972 a 1980, onde inclusive se acompanha uma evolução da filosofia de controle da broca. Assim no relatório de 1972, indica-sc o inicio do estudo das pragas dos canaviais dando ênfase às brocas, citando também que a possibilidade de encontrar va riedades tolerantes ao ataque da broca é uma esperança la gamente alimentada. Neste relatório jā se aponta uma gran de variabilidade de infestação pela broca nos canavia is do Centro-sul, não sỏ em termos locais, mas tambëm as vâ riedades de cana mostraram muita discrepância de um local para outro.

No seguinte relatório PLANALSUCAR (1973) of $\underline{e}$ rece-se dados sobre flutuação populacional da broca no Centro-sul, indicando-se uma maior população de adultos nos meses de janeiro e setembro. Confirmam-sc variações significativas da infestação pęla broca entre varicdades de cana e entre a interação local-varicdades, mas com ten tência de algumas variedades a apresentar menor infestas̆ão. Iniciam-se também estudos dos seus inimigos naturais c h 
perparasitos, mostrando que este complexo atinge a $23,7 \%$ das brocas coletadas, abrangendo taquinídeos, braconídcos e fungos entomopatógenos, esclarecendo ainda que os dados são vālidos ünica e exclusivamente para os locais e épocias em que foram obtidos. Destaque-se também a presença de Apanteles abditus Mues, como parasito nativo da broca.

No relatório PLANALSUCAR (1974) faz-se

primeira referência ao controle biológico de Diatraca spp. dentro do Programa Nacional para o controle das pragas da cana. Estudos são desenvolvidos visando a adaptação dos piz rasitos alienígenas Lixophaga diatraeae e

Apanteles flavipes. Paralelamente são efetuados trabalhos com os parasitos nativos $M$. minense, $P$. Claripalpis c Leskiopalpus diadema. Os estudos revelaram o fungo Beauveria bassiana que começou a aparecer com destaque no complexo parasítico da $D$. saccharalis. A flutuação populacional mostrou dile rença com relação ao período anterior. Em Alagoas desta caram-se diferenças de infestaçāo marcantes entre as diver sas regiões ecológicas do Estado, sendo muito menor a in festação na região ecológica da mata e central onde os fá tores climātico-topogräficos (alta.umidade, maior precip tação pluvial, topografia acidentada com muitas árcas de vārzeas, etc.) são desfavorāveis ao desenvolvimento da Diatraea spp. Neste ano iniciaram-se 1 iberações de $L$. diatraeae, P. claripalpis e A. blavipes.

o relatório PLANALSUCAR (1975) na continuida de do controle biológico da Diatraca spp, revelou os resul tados de um censo populacional mostrando que só duas cspec cies: 0 . saccharalis e 0 . Glavipenneila, causam projuizos econômicos à cana-de-açücar no Brasil. $\Lambda$ distrîbuição de D. saccharalis é geral, sendo a ünica cspécic responsívcl por danos à cana no Estado de São Paulo. Coî́lulu-se que 
os fatores temperatura, "chuva, umidade do ar, topografia, tipos de solo e variedades têm marcada influência no desen volvimento biológico de Diatraca spp. Apontou-se que no Es tado de São Paulo os adultos atingem os mais altos níveis populacionais nos meses de agosto a outubro. Na Bahia mos trou-se uma clara diferença de infestação em terrenos de "tabuleiro" e "massapé", sendo maior a intensidade de in festação nos primeiros. Repetiu-se a observação de que a susceptibilidade varietal da cana aos ataques da broca e um fator importante no desenvolvimento da praga e sua pro pagação, citando CP51-22, IAC52/150 e NA56-79 como as mais suscetiveis à braca, e IAC50\%134 e IAC48/65 entre as menos atacadas. 0 censo populacional dos inimigos naturais nat vos assinalou os taquinideos $M$. minense e $P$. claripalpis como elementos de controle natural muito importantes, mas mostrando um parasitismo relativamente baixo, sendo estas muito variāveis dentro das regiões ecológicas, ainda den tro do Estado de São Paulo. A multiplicação e liberação de parasitos como M. minense, $L$. diatraeae e $A$. flavipes é impulsionado, especialmente do último, em todos os Esta dos. Neste relatório, ampliado posteriormente por MENDES et alii (1976 a) encontram-se resuiltados de atração " de adultos de $D$. saccharalis por diferentes lâmpadas fluores centes, mostrando maior atração da lâmpada verde (F15'8G) e um sensível aumento no nümero de adultos capturados com a simples associação destas armadilhas luminosas com fêe meas virgens. Este mesmo relatório apresentou resultados da influência da irrigação da cana sobre a infestação pela broca, resultados que foram também ampliados por MI:NILLS et alii $(1976 \mathrm{~b})$, mostrando diferenças altamente significi tivas entre os tratamentos irrigados c o não irrigado, con cluindo que a irrigação da cana favorece o aumento de in festação pela broca. 
No relatörio PLANALSUCAR (1976) encontra-se uma avaliação do comportamento dos inimigos naturais nat $\underline{i}$ vos e alienígenas, mostrando que a mosca cubana, L. diatracae näo mostrou suficiente desenvolvimento para ser considera da um inimigo ativo de Diatraca spp. no Brasil, determinin do-se o abandono de novas tentativas de adaptação. No en tanto, A. blavipes que demonstrou uma extraordinäria cilpa cidade de adaptação, motivou muito entusiasmo pelas poss bilidades de sua manipulação no controle da hroca, destâ cando-se os resultados iniciais nos Estados de Alagoas o Bahia. Como consequência a multiplicação e liberação de pạ rasitos da broca são praticamente centralizados neste bra conídeo.

0 entusiasmo criado pelos sucessos iniciais de A. Glavipes no controle biológico da broca estā bem re tratado no relatório do PLANALSUCAR (1977) concluindo que durante os ûltimos três anos, houve uma redução substan cial na intensidade de infestação por Diatraca spp., dev $\underline{\mathbf{i}}$ do principalmente à introdução deste parasito, cuja adiap tação em onze regiões produtoras de cana no Brasil foi rea lizada com êxito, esclarecendo quo, no Estado de São Paulo, a introdução e adaptação de A. Glavipes sofreu um ' ccrto atraso, possivelmente devido a fatores climátológicos. In formou-se também de progressos na seleção de variedades ró sistentes aos ataques de Diatraea spp., catalogando como resistentes as variedades CB56-171, IAC48/65, IAC50/134, Co775 e CB45-155, incluindo 10 clones $R B$ da série 70. Rela taram-se também os resultados de estudos de parasitos e predadores de ovos da broca, concluindo-se que existe uma correlação estreita entre o fator irrigação c infestaçio de 0 . saccharalis, e que a entomofauna predadoŕa é impor tante na 1 imitação populacional de 0 . saccharalis, enquinn to que o microhimenóptero Trichogramma minucium é de baixó 
valor como parasito dos ovos de $D$. saccharalis na região sob observação.

No relatório PLANALSUCAR (1978) sob a refe rência de "Programa Nacional de Controle da broca da cana-de-açúcar: Diatraea spp", continuou-se relatando os suces sos de controle biológico com A. flavipes, mas com uma no tória ausência de dados em relação a relatórios anteriorcs, mostrando graficamente uma perfeita diminuição de infesta ção de 1975 a 1978, e um constante aumento de 1iberaçõos de parasitos, especialmente A. Glavipes. Neste ano se in cluiu a CB47-355 entre as variedades de cana resistentes à broca.

o relatório PLANALSUCAR (1979) jā faz refé rência a "Programa Nacional de Controle Integrado da Brocia Comum da Cana-de-Açúcar, Diatraea spp. no Brasil", e con tinua informando sobre os sucessos do controle biológico em base, principalmente, a multiplicações e liberações ma ciças de A. blavipes, cuja efetividade tem ficado amplamen te demonstrada. Fazem-se referências a trabalhos sobre controle químico, concluindo que alguns inseticidas, embo ra sobressaiam dentro de grupos de pesticidas testados, mos tram resultados, devidamente avaliados, que não justificam seu uso ou recomendação para programas de combate à Diatraea spp. Ressaltando que a resistência da cana-de-açü car à $D$. saccharalis è fundamental no contexto de controle integrado, definem-se como resistentes às variedades IAC50/134, CB45-155, CB56-156 e Co775.

O relatório PLANALSUCAR (1980), mostra qué as infestações em 1980 foram ligeiramente superiores is registradas em anos anteriores, mas a intensidade de infesti ção manteve-se inferior a 5\%, isto $\bar{c}$, dentro do parâmetro 
técnico econômico de controle da praga. Citam-se como pos síveis fatores responsāveis desta tendência de aumento ou desequilíbrio biológico: as ampliações das āreas com cana, aumento das äreas com cana-planta, introdução cle varieda des suscetíveis, condições de clima, etc. Menciona-se tạm bẻm uma redução do parasitismo médio anual devido possive 1 mente a condições climáticas que favoreceram o incremento dos níveis populacionais da broca, e que A. flavipes destị cou-se dentre todos os parasitos naturais da Diatraea spp., sendo isto possível consequência das liberações deste para sito, altamente incrementadas nestes últimos anos. 0 rela törio complementa-se com os resultados de resistência va rietal, mostrando como fontes de resistência as varicdides de cana $\mathrm{CB} 62-38, \mathrm{CB} 45-3, \mathrm{CB} 41-76$ e Mex57-473, além de 26 clones RB das sëries 70, 71,72,73 e 74 .

\section{Visando melhorar a técnica existente}

no Brasil, SGRILLO (1973) desenvolveu uma têcnica para cria ção da broca, baseado principalmente am alguns aparelhos desenvolvidos para automatizar algumas operações, utilizan do a dieta de HENSLEY e HAMMOND (1968). O método permitiu a obtenção de um número suficientè de insetos para testes de ecologia ou de laboratörio, esclarecendo porém que não podia ser considerado como método de criação massal. No en tanto o trabalho contribuiu os seguintes dados biológicos da broca em laboratório: a fecundidade é maior quando se usa na cópula três machos para cada fêmea; as fêmeas vivem mais que os machos adultos; o espaço disponível influcncia na duração da vida das fêmeas, aumentando-a, mas não tcon influência na duração da vida dos machos.

Estudando aspectos biológicos da 0 . saccharalis em condições naturais e a frequência do scu acasalamento, GUEVARA (1976) chegou às scguintes conclu 
sões: o ciclo evolutivo, em condições de campo (de agosto a novembro), variou de 73 a 102 dias, desde a postura at a emergência dos adultos, sendo 9 dias na fase de ovo, 57 a 79 dias na larva e 7 a 14 para a crisälida. Nestas condi ções for am obtidos 13 adultos a partir de 373 ovos, repre sentando uma viabilidade de apenas 3,48\%. Em condições de laboratório, os machos não copulavam mais de uma vez a mes ma fêmea (somente um macho copulou 2 vezes, porêm com 10 meas diferentes) e nenhuma fêmea foi copulada mais de uma vez, nem quando confinada com atê. 4 machos (quando värias fêmeas foram reunidas com värios machos, apcnas $5,5 \%$ copu laram 2 vezes). No entanto, sob condições de campo, as fê meas puderam ser copuladas atē quatro vezes.

Num estudo da população da $D$. saccharalis $\mathrm{cm}$ quatro regiões canavieiras do Estado de São Paulo, através de levantamentos mensais, WALDER (1976) mostrou que: a) o indice de infestação médio durante o período de safra de 1975 foi de $11,7 \%$; b) houve maior porcentagem de formas imaturas durante janeiro a maio, coletando-se neste perío do $64 \%$ de todas as formas imaturas e $82 \%$ das lagartas pe quenas do total de individuos coletados durante o ano); c) o período de maior concentração de formas imaturas de $D$. saccharalis coincide com o período de maior crescimento ve getativo da cana; d) a temperatura e umidade do ar foram os fatores meteorológicos que mais influíram na flutuação populacional da praga; e) a $D$. saccharalis completou qua tro gerações anuais, nás regiões estudadas, ocorrendo a primeira em outubro-novembro, a segunda em dezembro-janc ro, a terceira em fevereiro-março e. a quarta começa cm abril e continua em diapausa até setembro; l) uma pequenat parte das lagartas da quarta geração não entram on diapan sa, completando normalmente seu ciclo, mesmo durante os me ses mais frios e secos do ano. 
MENDES et alii (1978) num estudo com adultos da broca capturados em armadilhas luminosas, no Estado de São Paulo, mostraram: 1) que a altura preferida do vôo $\overrightarrow{\mathrm{e}}$ tangenciado superiormente a cultura de cana; 2) que a hora preferida de vôo concentra-se das 19:00 às 4:00 horas, com 2 períodos predominantes das 22:00 às 23:00 e das 24:00 à 1:00 hora, e 3) coletou-se maior número de insetos na fase de lua quarto minguante e nova.

Outro estudo efetuado no Estado de São paulo por BOTELHO et alii (1979 b), sobre dispersão dos adultos machos da broca, mostrou que estes se afastam da origem uma distância média de $42,5 \mathrm{~m} / \mathrm{dia}$.

Os resultados de estudos sobre flutuações po pulacionais de adultos machos da broca efetuados em cana viais comerciais do Estado de São Paulo de 1974 a 1977, usan do fêmeas virgens como atraentes (TERÂN, 1979 a) mostraram maior captura em cana do que em milho e as capturas aumen taram quando aumentou o número de fêmeas virgens por a rma dilha. Nos canaviais registrou-se o pico populacional máx mo em dezembro, picos secundários èm julho-agosto e feve reiro e clara diminuição populacional de março a junho. No entanto, ressaltaram as grandes variações de um local a ou tro e de um ano a outro, sendo difícil definir uma situi ção pela média. Por outro lado, observou-se que a captura de machos foi mais satisfatória que a captura com armadi lhas luminosas para estes estudos de flutuações populacio nais, pela sua maior especificidade e facilidade de opera ção. A influência de fatores climäticos foi reconhccida co mo causa das maiores variações, que devem ser modificidas pelas variacões na composição dos hospedeiros vegetais, determinando assim, outras variações menorcs. 
BOTELHO et alii (1978 a), em estudos

seme

lhantes de 1972 a 1975 usando armadilhas luminosas, chega ram às seguintes conclusões: 1) os adultos cstão prescntes ao longo de todo o ano, embora os números flutuem conside ravelmente, 2) as mêdias populacionais mostraram o pico maior na segunda quinzena de agosto e dois picos secundá rios na primeira quinzena de janeiro e a segunda quinzena de março, 3) os fatores meteorológicos são responsáveis por 41,3\% das flutuações, sendo o mais importante as varia ções térmicas responsáveis por $27,8 \%$ deste efeito.

O trabalho de MACEDO et alii (1978) sobre suscetibilidade das principais variedades da cana à brocia no Centro-sul do Brasil, confirma e amplia os resultidos relatados pelo PLANALSUCAR $(1978,1979)$. As variedades mia is resistentes (apesar do efeito do local, período de levanta mento e do ciclo do corte) foram IAC50/134, CB45-155, CB56-156 e Co775, enquanto que as mais suscetiveis foram IAC52/150, CP51-22, NA56-79 e CB41-76. Outra conc1usão im portante foi que as canas-plantas ou de primeiro corte, fó ram mais atacadas e que o período de maior infestação foi julho, sendo tambëm registradas differentes infestaçõcs nas localidades, com a maior infestação na Usina Bom Jesus.

Um primeiro intento de desenvolver modelo ma temâtico para as populações da broca no Brasil foi reito por SGRILLO (1979), para estudar a possibilidade teórica de aplicação da Técnica do Indivíduo Estéril (TIE). 0 mode 1o foi construído com base em levantamentos de campo real lizados em 1976 em quatro regiões canaviciras do Estado de São Paulo, acumulando-se dados referentes a densidade popu lacional de lagartas e pupas do inseto, auxiliado por in formações sobre a flutuação populacional de adultos e de alguns predadores. Determinou-se que as lagartas seguem umil 
distribuição espacial năo diference da binomial negativa e desenvolveu-se um plano de amostragem scquencial para es tas lagartas. Foi verificada a ocorrência de diapausa cm lagartas grandes, mostrando corrclaça com fotoperíodo e temperatura. Estabeleceu-se que o número de graus dias nc cessärios ao inseto completar uma geração é de 954. Detcrmi nou-se em laboratório que machos adultos irradiados com 50 krad de radiação gama $(60 \mathrm{Co})$ produzem progênie não viável e atravẻs do modelo construído teórica e matcmaticimente concluiu-se que a liberação de insetos estéreis em número igual aos existentes no campo, durante as três primeiras gerações, seria um método eficiente para o controle das po pulações do inseto. A liberação de insetos estércis cm nü mero nove vezes superior aos existentes no campo, durante a primeira geração, seria igualmente eficientc.

Num estudo ecológico efetuado em canaviais comerciais do Estado de São Paulo de 1975 a 1977, sobrc controle natural de ovos da broca, TERAN (1980 a) mostrou que os predadores dos ovos são importantes, como foram de finidos na Louisiana. Os resultados assinalaram uma média geral de $76,16 \%$ de controle dos ovós, com variações marcian tes de um local para outro e de um ano a outro. Os predil dores foram os maiores responsáveis por esse controlc nat ral $(63,64 \%)$, enquanto que os parasitos responderam só por $3,90 \%$ da mortalidade, e o restante $8,63 \%$ foi devido a ou tros fatores. Esclareceu-se que estes dados possivelmente estão encobertos pela ação final dos predadores mastigado res que não fazem distinção entre ovos sadios c aqueles pâ rasitados ou sugados. Comenta-se também que as grandes val riações deste controle natural sejam decisivas no posterior sucesso das populações da broca.

Este estudo serviu de base para outros efe 
tuados por GRAVENA et alii (1980), concluindo que as formi gas foram eficientes predadoras de ovos de $D$. sacchanalis, que o complexo de predadores tem real participação no con trole biológico natural, e que a atividade dos predadores mastigadores è maior do que dos predadores sugadores.

Num estudo de correlação entre intensidiade de infestação e indices populacionais da broca, MENIllis et alii (1980) mostraram uma alta correlação positiva entre esses 2 parâmetros, concluindo que é possível cst 1 . mar o indice populacional da praga (larvas e pupas) basca do na intensidade de infestação, atravês de equações de rẹ gressão linear.

Procurando informaçōes quantitativas do com portamento da broca no hospedeiro alternativo mais plant a do no meio dos canaviais, TERAN (1980 b) efetuou um cstuclo sobre a densidade larval da broca e seu controle natural no milho. Este estudo entre outros fatos mostrou que: 1) o parasitismo por braconídeos è maior no milho que na ca na, comparāvel ao de $P$. claripalpis, sendo ainda dominantc a M. minense no local do estudo (Macatuba, SP), 2) o para sitismo combinado é mais baixo em milho que $\mathrm{cm}$ canaviats vizinhos, 3) nos milharais, os entomopatógenos são mais importantes que os outros agentes de controle natural, c 4) a densidade larval da broca è maior em milharal mais denso, adubado e em estágios mais avançados de crescimento do milho.

o controle biológico é, sem dūvida, o métoclo de controle da broca mais utilizado e GALLO (1980) fez umil revisão da sua evolução atẽ a situação atual, 1 embranclo que no Estado de São Paulo, o impulso inicial foi dado pe 10 Departamento de Entomologia da ESALQ-USP. 
Por outro 1ado, o controle químico atravês de inseticidas foi revisado recentemente por DEciASPARI et alii (1981) manifestando que, nos trabalhos efetuados de 1976 a 1979, os resultados permitiram concluir que o con trole químico da $D$. saccharalis na região estudada (Con tro-sul do Brasil) foi inviável economicamente, face aos baixos indices de eficiēncia. No entanto é necessārio revi sar os resultados de MATTOS et alii (1976) e de LONG et alii (1976), especialmente dos ültimos, que mostram não só possibilidades tēcnicas, mas tambēm econômicas, de contro le da broca com inseticidas em condições de alta infestä ção se estas puderem ser detectadas com antecedência. l'o rẻm, o maior problema reside no perigo destes produtos nia contaminação do ambiente e na interferência, a longo prizo, no equilíbrio natural da maioria dos canaviais.

Desenvolvendo uma metodologia de aplicas̃̃o de inseticidas granulados para ensaios do manejo integrado da broca, NEVES, (1981) estudou tambëm alguns aspectos da ação dos artrópodos predadores desta praga, chegando as se guintes conclusões: a) a aplicação de inseticidas com gra nuladora costal JACTO PL-45 pode ser recomendada para en saios de controle da broca em cana, b) esta aplicação deve ser feita pelos dois lados de cada parcela para que hilja uniformidade na deposição, c) a altura limite do canavial para aplicação destes inseticidas granulados foi de $2 \mathrm{~m}, \mathrm{~d}$ ) a coleta de grânulos é feita principalmente pelas folhas do cartucho e folhas ainda verdes, sendo pouco eficicntes as coletas em folhas basais senescentes, e) o controlc da broca com carbaryl e $B$. thuringiensis equiparou-se ao con trole natural não havendo difeŕença estatistica signilici tiva entre eles, f) o aldrin formulado $\mathrm{em}$ milho triturado foi eficiente na eliminação dos artrópodos predadores cm ensaios de campo, e provocou ressurgência da praga, e g) 
as formigas constituiram-se no grupo de predildores de mior abundância, colocando-sc, em seguida, as aranhas.

Numa contribuição ao estudo do controle inte grado da broca, MATTOS (1982) relata os resultidos de 2 ex perimentos efetuados em Capivari, SP, com a variedacle NA.56-79, sujeito a diversos tratamentos com carbofurin (Fu radan 5G), discriminando número de aplicações e intervalos entre as aplicações. Pelos resultados obtidos e para as condições dos experimentos, concluiu que: a) todos os trä tamentos provocaram redução na intensidade de infestişĩo da broca, b) o tratamento mais eficiente no controle di broca, foi a de 4 aplicações de carbofuran aplicado de ou tubró a fevereiro, c) a maior intensidade de ataque da bro ca verificou-se nos $2 / 3$ inferiores do colmo, d) os trat a mentos químicos deslocaram o pico populacional da praga, e e) apenas o tratamento de 3 aplicações, em outubro a fe vereiro, aumentou significativamente a produção de cana-de-açúcar. Este trabalho conseguiu demonstrar tambeñ que a praga reduziu a produtividade de campo da cana-de-açúcar em 19,74\% quando comparados a testemunha (com 18,23\% de en trenós brocados) e o tratamento com 19 aplicaçõcs de carbo furan que conseguiu manter a infestação a nível de 2,02: de entrenós brocados, mostrando claramente que a broca não só produz perdas na indústria, mas também no campo.

0 trabalho de CASTILHO (1982) sobre introdu ção de Apanteles flavipes (Cam, 1981) para o controle bio lógico da broca na região de Santa Bärbara D'Oeste, SP, mo trou a viabilidade de criação do parasito em grande cscal la em laboratório, sua ação parasítica $\mathrm{cm}$ condições de can po, relação de causa e efeito do parasitismo c danos causa dos pela praga, a interação entre populações do parasito introduzido e as populações de parasitos nativos, interä 
coões entre a população do parasito introduzido e os agen tes climāticos. Concluiu que: a) o. A. Glavipes $\overrightarrow{\mathbf{e}}$ um paras to de fácil criação em laboratório, ideal para o estabcle cimento de programas de controle biológico da broca cm grande escala, b) esta espēcie parasita lagartas da broca com grande facilidade, nos canaviais da região estudadi, c) a população do parasito apresentou uma baixa capaciclia de de dispersão nos canaviais da região estudada, d) as co lônias do parasito depois de estabelecidas permaneceram nos canaviais, sem a interferência do homem, e) a reprocluciõo do parasito em condições de campo é menor que a observala em laboratório, f) o parasito introduzido integrou-se no complexo parasitico dos inimigos naturais da broca na re gião, destacando-se por apresentar maior taxa de parasitis mo e maior porcentagem de participação no complexo, g) A. blavipes atua em períodos quando a espécie de parasito na tivo mais importante da região (M. minense), encontri-sc em baixa atividade, ocorrendo, assim, uma alternância recí proca, aumentando a regularidade do parasitismo o ano to do, e h) a ação do parasito introduzido foi responsável pec la queda das porcentagens de Intensidade de Infestação observada na região estudada.

Seguindo uma linha filosófico-estratégicia um pouco diferente, entomologistas da COPERSUCAR partiram pai ra o manejo integrado da broca, embora sem contar com os suficientes alicerces para esse objetivo. Assim, TERKN e NOVARETTI (1978) relataram os seguintes resultados têcn cos obtidos em 2 Usinas, organizando e integrando atividil des que visam assinalar, com antecedencia, os pontos de de sequilíbrio, para serem corrigidos com liberações dirigg das de parasitos (especialmente M. minense). Isto cquivale a monitorar os extensos canaviais comerciais fazendo uso de conhecimentos ecológicos da praga e seu hospedeiro. 
Com esses resultados iniciais, foi proposto pelos mesmos autores (TERAN e NOVARETTI, 1980 a) um esque ma de manejo integrado da broca da cana-de-açúcar, baseado por enquanto só num método de controle biológico, isto Ë: utilização de parasitos larvais da broca em liberações di rigidas, a canaviais em crescimento e com populações dese quilibradas, que devem ser detectados, com antecedência c oportunidade, entre os numerosos canaviais de uma Usini, i custos razoáveis. Os resultados econômicos deste mancjo integrado (TERAN e NOVARETTI, 1980 b) confirmaram a vill $\underline{i}$ dade deste esquema em termos de canaviais comerciais, fal tando só um aperfeiçoamento do sistema e uma integraçiócom outros mëtodos de controle a fim de solucionar os proble mas ou infestações que ainda não foram totalmente superä das, em se tratando de resultados reais em extensos can a viais comerciais. 
3. MATERIAL E METODOS

$$
\text { Efetuaram-se dois tipos de estudos: }
$$

a) Levantamentos extensivos de campo, em canaviais comer ciais e experimentais de Usinas.

b) Testes controlados, instalados nas Estações Experimen tais da Copersucar e em algumas Usinas.

Em ambos os casos, os estudos visavam avaliar a influência de alguns componentes ecológicos na dinâmica populacional da broca e seus inimigos naturais.

3.1. Idade do canavial.

Entende-se por idade do canavial o ano dia cul tura após o plantio, sendo que o primeiro corte é aquelc cor respondente à cultura no seu primeiro ciclo vegetativo, o se gundo corresponde ao segundo ciclo vegetativo após o corte do primeiro e assim sucessivamente.

\subsubsection{Levantamentos de infestação $f$ ina 1}

Estes são basicamente levantamentos de dinos causados pela broca aos canaviais, mas preferiu-se chillílos de levantamentos de infestação por ser o termo util i 
zado rotineiramente, e final porque se refere ao dano ob servado quando as canas chegaram à indústria, isto é, detcer minado no momento do corte ou colheita do canavial para seu processamento na indústria ou para sua utilização no plann tio de novos canaviais.

Os levantamentos foram efetuados através de amostras retiradas ao acaso dentro dos canaviais. As amos tras consistiram de canas examinadas internamente (cortan do-as longitudinalmente ao meio), procurando examinar um mínimo de 20 canas por hectare de canavial, a fim de permi tir a amostragem de todos os canaviais colhidos. Anotarim-se tanto a quantidade de canas como a de entrenós brocuca a dos em relação ao total de canas e entrenós examinados. Des ta forma, determinaram-se as porcentagens de canas e cutre nós broqueados por simples cảlculo de regra de três. Isto resultou nos indices de "intensidade de infestação" ( $\%$ dc entrenós broqueados) para cada unidade amostrada.

Os valores anotados em formulärios de campo foram transferidos para formulārios resumo, agrupando-os por unidade de plantio (talhão, quadra, lote, etc.) com a mesma variedade de cana e idade do canavial.

Os dados levantados durante as safras de 1977 a 1981, em canaviais de diversas Usinas, foram agrupa dos de acordo com a idade do canavial.

\subsubsection{Levantamentos populacionais}

Estes levantamentos, chamados de colctis, efe tuaram-se ao longo de 1981, em canaviais imaturos de 3 Us $i$ nas representativas das regiões de Jaú (Barra (irande), Sér tãozinho (Santa Luiza) e Piracicaba (Santa Cruz S $\Lambda$ ), todas localizadas no Estado de São Paulo. 
O trabalho de campo consistiu de coletas ma nuais das formas imaturas da broca e seus parasitos em ca naviais jovens. As coletas foram direcionadas, procurando amostragens ao acaso em faixas distanciadas uniformemente dentro dos canaviais. Essas coletas foram também dirccio nadas só às canas jā inutilizadas pelo ataque da broca ("coração ou olho morto"), evitando-se assim a destruiçĩo dos colmos aproveitāveis.

Por razões präticas e por facilidade opera cional não foi possível medir a ărea amostrada, registran do-se sỏ as horas efetivamente gastas nessas coletas clen tro dos canaviais, a fim de contar com um parâmetro de len didade populacional relativa, isto $\vec{e}$, coleta por hori-ho mem. Os dados são comparâveis dentro da mesma Usina, lesde que os levantamentos foram realizados quase sempre com a mesma equipe de trabalhadores, garantindo uniformidade nos mesmos.

O material biológico, coletado com a prcocu pação de causar o minimo de injưrias durante a manipulação, foi registrado em formulários individuais, anotando-sc as caracteristicas do canavial (Figura 1). As formas larvais da broca foram acondicionadas individualmente $\mathrm{em}$ caixi nhas plásticas circulares e transparentes de $63 \mathrm{~mm}$ de di ia metro e $23 \mathrm{~mm}$ de altura, alimentadas com "dieta artificial" à base de feijão, germe de trigo e levedura como fontes protéicas, até a transformação em crisālidas (broca) ou cm pupārios (seus parasitos). Esperou-se um tempo suficiente (de 15 a 20 dias) para que ocorresse o parasitismo dias brocas. Este parasitismo foi calculado por simples regra de três. Os dados finais dos formulärios, após estas trans formações, foram transferidos a resumos, junto com os dil dos de densidade populacional relativa e dados increntes aos canaviais amostrados. 
PARASITISMO NO CAMPO DE Diotroeo socchorolis (COLETA)

Localizocöo

Dato do Coleto Voriedade idade meses ) Observocōes :

COLETA

larvos grondes o médios ...
pupos (crisólidas)
pupários do compo (parasitos)
doentes o predados . . . . . . .

TOTAL (poro cólculo de porositismo)

lorvos pequenos

TOTAL GERAL DA COLETA

horos efetivos do coleto

COLETA POR HORA \& HOMEM (2): (3)

Porositodos por:

$\%$

Metogonistylum minense . . . . . . . . (1)

Porotheresio cloripolpis . . . . . . : (1)

Broconídeos ............: (1)

Outros . . . . . . . . . . . : (1)

TOTAL DO PARASITISMO NO CAMPO ....: (1)

Figura 1. Modelo de formulário utilizado nos levantamentos populacionais. 
Esses dados agrupados em função da idade do canavial foram relacionados em tabelas e gräficos compilial tivos para cada Usina.

3.1.3. Testes de controle natural de ovos da brocia

Os testes foram desenvolvidos dentro de cillil viais próximos, com características semelhantes (mesmal vî riedade e desenvolvimento vegetativo), porém de diferente corte.

Uma sẻrie de 8 testes foi conduzida na listal ção Experimental de Jaũ do Centro de Tecnologia Copersuciar (CTEJ), utilizando-se 2 canaviais da variedade I $\$(52 / 150$ (uma de primeiro corte comparada com outra de quarto cor te), no período de março a setembro de 1978 .

Outra sērie de 3 testes foi conduzida na Usina Barra Grande de Lençóis Paulista, utilizando-se 2 ca naviais da variedade NA56-79 (uma de primeiro corte compil rada com outra de terceiro corte), no período de setcmbro a novembro de 1978 .

Para os testes utilizaram-se posturas obt das das criações massais da broca nos respectivos locais. Essas posturas foram previamente preparadas em pedaços ou tiras de papel sulfite, contendo uma postura com 5 a 15 ovos, marcando-se a lápis o total de ovos e identificando-se o pedaço de papel com uma letra, para garantir a sua posterior identificação, em caso de destruição total pelos predadores ou por algum acidentc. Esses dados foram anoti dos em formulärios padronizados para estes testes, onde tambẻm se registraram as características do canavial ut lizado e outros dados considerados importanies (Figura 2). 
CONTROLE NATURAL (INDUZIDO). DAS POSTURAS DE Diotroøo socchorolis USINA LOCALIZACAXO

CANA

\begin{tabular}{|c|c|c|c|c|c|c|c|c|c|c|c|}
\hline \multirow{3}{*}{ DATA } & \multirow{3}{*}{$\begin{array}{c}\text { PEDACO } \\
\text { DE } \\
\text { PAPEL }\end{array}$} & \multirow{3}{*}{$\begin{array}{l}\text { NÚMERO } \\
\text { DE OVOS }\end{array}$} & \multirow{2}{*}{\multicolumn{2}{|c|}{$\begin{array}{l}\text { OVOS PARA } \\
\text { SITADOS }\end{array}$}} & \multicolumn{4}{|c|}{ OVOS PREDADOS } & \multirow{2}{*}{\multicolumn{2}{|c|}{$\begin{array}{l}\text { OVOS NĀO } \\
\text { ECLODIOOS }\end{array}$}} & \multirow{3}{*}{ OBSERVACరES } \\
\hline & & & & & \multicolumn{2}{|c|}{ Mostigados } & \multicolumn{2}{|c|}{ Sugados } & & & \\
\hline & & & N: & $\%$ & $\mathrm{~N}$ & $\%$ & N: & $\%$ & $\mathrm{~N}:$ & $\%$ & \\
\hline & & & & & & & & & & & \\
\hline & & & & & & & & & 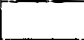 & 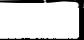 & \\
\hline & & & & & & & & & . & 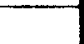 & \\
\hline & & & & & & & & & & & \\
\hline & & & & & & & & & 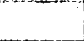 & & \\
\hline & & & & & & & & & & & \\
\hline & & & & & & & & & - & 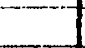 & \\
\hline & & & & & & & & & - & 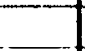 & \\
\hline & & & & & & & & & 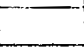 & - & \\
\hline & & & & & & & & & $\dot{x}$ & & \\
\hline & & & & & & & & & - & & \\
\hline &. & & & & & & & & 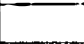 & 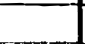 & \\
\hline & & & & & & & & & & - & \\
\hline & & & & & & & & & & 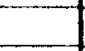 & \\
\hline & & & & & & & & & & $\ldots$ & \\
\hline & & & & & & & & & & & \\
\hline & & & & & & & & & & & \\
\hline & & & & & & & & & & & \\
\hline & & & & & & & & & & & \\
\hline & & & & & & & & & & & \\
\hline & & & & & & & & & & & \\
\hline & & & & & & & & & & & \\
\hline & & & & & $\therefore$ & & & & & & \\
\hline & & & & & & & & & & & \\
\hline & & & & & & & & & & & \\
\hline & & & & & & & & & & & \\
\hline & & & & & & & & & & & \\
\hline & & & & & & & & & L... & & \\
\hline & & & & & & & & & & & \\
\hline - & & & & & & & & 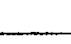 & $\ldots$ & & \\
\hline & & & & & & & & & & & \\
\hline & & & & & & & & & & & \\
\hline & & & & & & & & & & & \\
\hline & & & & & & & & & & & \\
\hline & & & & & & & & & & & \\
\hline & & & & & & & & $\ldots$ & - & & \\
\hline & & & & & & & -1 & $\ldots$... & $\ldots$ & -1 & \\
\hline & & & & & & - & ....... & ............... & - & & \\
\hline & & & & & & & & $\cdot$ & $\ldots$ & & \\
\hline & & & & & & & & & - & & $\ldots$ \\
\hline & & & & & & & & & & & - \\
\hline
\end{tabular}

$\overrightarrow{\overrightarrow{6}}$

Figura 2. Modelo de formulário utilizado nos testes de controle natural de ovos do broca. 
A seguir, os pedaços de papel com os ovos ló ram distribuídos uniformemente nos canaviais em estudo, i xando-as na folhagem da cana, próxima ao colmo, com alrine tes de cabeça grande e colorida, para facilitar posterior mente a sua localização. Efetuaram-se, a seguir, revisóes periôdicas, trazendo-se para o laboratório todos os pedia ços de papel cujos ovos desaparcceram (mastigados) ou fo ram sugados (posturas "murchas" ou vazias), sendo que no final foram retirados todos os pedaços de papel assim yue aparecia alguma postura com ovos no estágio de "cabcça pre ta" (embrião totalmente formado e prestes a eclodir).

o "destino" de cada postura foi registrado no formulário correspondente anotando-sc também, as latis de colocação e retirada das posturas.

Os dados calculados e resumidos foram poste riormente tabelados e analisados estatisticamente.

3.1.4. Testes de sobrevivência e duração do ciclo biológico

Os testes foram conduzidos também dentro de canaviais próximos, semelhantes, porém de diferentes cortes.

De vårias tentativas feitas, só foi possível concluir uma série de 3 testes conduzidos na Usina Barra Grande de Lençóis Paulista, utilizando-se de 2 canavialis da variedade NA56-79 (uma de primeiro corte comparala com outra de terceiro corte), no período de outubro-novembiro de 1978 .

Os trabalhos iniciaram-se com o isolamellto de touceiras (normalmente 5 por tratamento), climinando-se as canas vizinhas pạa anular ou minimizar a migraçio las 
larvas recêm eclodidas para as touceiras isoladas. A seguir, foi eliminado todo vestígio de formas imaturas da brocil des tas touceiras isoladas. Imediatamente após, infestaram-sc as touceiras com larvas recém eclodidas ou com ovos do es tảgio "cabeça preta" fixados na folhagem das canas. $\Lambda \mathrm{s}$ ca nas foram revisadas a cada 4 a 5 dias num período de 20 dias aproximadamente ( 4 a 5 revisões) para se eliminar to da postura originada das populações naturais de campo.

As revisões foram reiniciadas 30 a 35 dials apôs a infestação, procurando-se sinais da presença da broca, principalmente pelos "furos de emergência" nos col mos, caracterizados pelo tamanho maior e ausência de de tritos frescos, indicativos da finalização da lasce larval deste inseto.

As canas detectadas nesse estado foram trans feridas para os laboratórios, onde após a remoção cuidialo sa da pupa (crisālida) ou da broca totalmente desenvolvidib estas foram mantidas individualmente em caixinhas plásti cas para acompanhar a sua transformação em adulto, fazen do-se a anotação no formulário cợrespondente (Figura . 3). Registraram-se desta forma, não só o total de pupas e adulu tos obtidos, mas tambēm o período larval (lagarta) c pupal e sexo do adulto emergido. A observação desses períoclos são importantes por serem os mais longos e de miior dura ção no ciclo biológico da broca.

Os dados resumidos foram posteriormente tiloc lados e submetidos a anālise estatística.

3.1.5. Testes sobre capacidade reprodutiva de 0. saccharalis 
CONTROLE NATURAL E DURACĀO DO CICLO BIOLÓGICO DA BROCA

Local

Tratamento

Número larvas/touceira Número touceira Total

\begin{tabular}{|c|c|c|c|c|}
\hline \multicolumn{2}{|c|}{ DATA DE } & \multirow{2}{*}{$\begin{array}{l}\text { INDIVÍDUOS } \\
\text { LOGRADOS }\end{array}$} & \multirow{2}{*}{$\begin{array}{l}\text { OURACAO DO } \\
\text { PERIODO } \\
\text { LARVA + PUPA }\end{array}$} & \multirow{2}{*}{ OBSERVACరEES } \\
\hline $\begin{array}{l}\text { ECLOSAO OA } \\
\text { LARVA }\end{array}$ & $\begin{array}{c}\text { EMERGENCIA } \\
\text { DO ADULTO }\end{array}$ & & & \\
\hline & & & & \\
\hline & & & & \\
\hline & $\circ$ & & & \\
\hline & & & & \\
\hline & & & & \\
\hline & & & & \\
\hline & & & & \\
\hline & & & & \\
\hline & & & & \\
\hline & & & & \\
\hline & & & & \\
\hline & & & & \\
\hline & & v & & \\
\hline & & & & \\
\hline & & & & \\
\hline TOTAL & & & & \\
\hline MÉDIA & & & & \\
\hline
\end{tabular}

Figura 3. Modelo de formulório utilizado nos testes de sobrevivêncio e duracão do ciclo biológico. 
Os testes iniciaram-se com coletas macicas de pupas e larvas totalmente desenvolvidas, em canavials próximos, semelhantes, porém de diferentes cortes.

Para uma série de 8 testes utilizaram-sc as coletas de 2 canaviais da variedade NA56-79 (uma de prime ro corte comparada com a outra de quarto cortel locilizadas na Usina São Josê ZJ de Macatuba, SP, em março de 1978.

Para outra série de 2 testes utilizaram-sc as coletas de 2 canaviais da variedade IAC52/150 (uma de pri meiro corte comparada com outra de quarto corte) localizi das no CTEJ, em novembro de 1978 .

Apesar dessas coletas maciças, não foram ob tidos suficientes casais de adultos para os testes no labo ratório, uma vez que foi difícil-sincronizar a emergência de machos e fêmeas no mesmo dia.

Os testes propriamente ditos foram conduzi. dos em laboratório, a partir dos casais obtidos. Os casia is foram confinados em tubos de PVC de $21 \mathrm{~cm}$ de altura por $10 \mathrm{~cm}$ de diâmetro, forrados internamente com papel sulfite, sobre o qual foi realizada a oviposição. Os papéis foram trocados diariamente até a morte das fêmeas, a fim de con seguir a oviposição total. As posturas foram colocadas cm Placas de Petri até a eclosão das larvas, registrando-se o total de ovos e de larvas eclodidas em formulários cspe ciais (Figura 4). Com esses dados e por simples cálculos aritméticos foram determinadas a fecundidade (n? de ovos por fêmea) e a viabilidade dos ovos (o de larvas celoll das) para cada tratamento (idade de canavial em que foram criados os estágios imaturos da broca). Posteriormente os dados de viabilidade foram submetidos à análise cstatíst ca. 
REGISTRO DA FECUNDIDADE E DA VIABILIDADE DE D. soccharalis.

LOCAL DE ORIGEM

cana

\begin{tabular}{|c|c|c|c|c|c|c|}
\hline $\begin{array}{c}\text { DATA DE } \\
\text { ACASALAMENTO }\end{array}$ & $\begin{array}{l}\text { DIAS DE } \\
\text { OVIPOSICĀO }\end{array}$ & $9 ?$ & $\begin{array}{l}\text { TOTAL } \\
\text { OVOS } \\
\text { (1) }\end{array}$ & $\begin{array}{l}\text { OVOS } \\
\text { VIAVEIS } \\
\text { (2) }\end{array}$ & $\begin{array}{c}\text { VIABILIOADE } \\
\% \\
(2):(1)\end{array}$ & OQSERVACర̄ES \\
\hline & & & & & & \\
\hline & & & & & & \\
\hline & & & & & & \\
\hline & & & & & & \\
\hline & & & & & & \\
\hline & & & & & & \\
\hline & & & & & & \\
\hline & & & & & & \\
\hline & & - & & & & \\
\hline & & & & & & \\
\hline & & & & & & \\
\hline & & & & & & \\
\hline & & & & & & \\
\hline & & & & & & - \\
\hline & & & & & & \\
\hline & & & & & & \\
\hline & & & & & & \\
\hline & & & & & & \\
\hline & & & & & & \\
\hline & & & & & & \\
\hline & & & & & & \\
\hline & & & & $\bullet$ & & \\
\hline & & & + & $-\quad-\quad$ & & \\
\hline & & & & & & \\
\hline & & & & & & \\
\hline & & & & & & \\
\hline & & & & & & \\
\hline & & & & & & \\
\hline & & & & & & \\
\hline & & & & & & \\
\hline & & & & & & \\
\hline & & & & & & \\
\hline & & & & & & \\
\hline
\end{tabular}

Figura 4. Modelo de formulório utilizado nos testes sobre copacidode reprodutiva dos adultos da broca. 
3.2. Idade da cana (estado fenológico)

Entende-se por idade da cana o estado de crescimento da planta, dentro do mesmo ciclo vegetativo. Desta forma procurou-se estudar a influencia dessc fator na infestação e evolução das populações da brocia.

\subsubsection{Levantamentos de infestação final}

Efetuaram-se os levantamentos conforme a me todologia descrita em 3.1.1 nos canaviais da Usina Barra Grande de Lençôis Paulista durante a colheital de 1979. Nes te caso, registrou-se a idade da cana cm mescs no momento da colheita, para agrupar os dados de infestaça $\mathrm{cm}$ funçio dessa variação.

\subsubsection{Levantamentos populacionais}

Para estes levantamentos utilizou-se a meto dologia descrita em 3.1.2, ao longo de 1981, cm canaviais imaturos das Usinas: Barra Grande, Santa Luiza c Santil Cruz S.A., abrangendo vários municípios do listado de são Paulo. Porém, neste caso, os dados foram agrupados $\mathrm{cm}$ run ção da idade da cana.

3.2.3. Testes de controle natural de ovos da broca

Os testes foram conduzidos conforme a metodo logia descrita em 3.1.3, em dois pontos adjacentes de um canavial da mesma variedade c corte, porém, em diferente estado de crescimento.

Uma série de 3 testes foi concluzido num canla vial da variedade IAC52/150 de 30 corte (ressocia), de maio 
a julho de 1978, localizado na CTEJ. Uma parte desse canavial foi cortado em outubro-77, portanto, cssa parte esta va com 7 a 9 meses durante os testes. A outra parte foi cortada em março-78, portanto, essa parte estava com 2 a 4 meses durante os testes.

Outro teste foi conduzido num canavial da variedade $C B 41-76$ de 29 corte (soca), localizalo na Usina Barra Grande de Lençóis Paulista em outubro-78. Uma partc desse canavial foi cortado em setembro-77, portanto, cssa parte estava com 11 meses durante o teste. A outra partc foi cortada em junho-78 e estava com 4 meses durante o tes te.

3.2.4. Testes de sobrevivência e duração do ciclo biológico

De värias tentativas, foi completado somente uma sêrie de 2 testes, efetuados num canavial da variedadc CB41-76 de 29 corte (soca), localizado na Usina Barra Crancle de Lençóis Paulista. Os testes foram iniciados em outubro-78, nas 2 partes desse canavial, com diferentes idades de crescimento. Uma parte do canavial foi cortado $\mathrm{cm}$ setcm bro-77, encontrando-se, no início dos testes, com 11 mescs de crescimento. A outra parte foi cortada em junho-78, es tando assim com 4 meses no início dos testes.

Os procedimentos experimentais foram os mes mos do item 3.1.4.

\subsection{Varicdades de cana}

Esta característica do hospedeiro foi cxten sivamente estudada, comparando as varicdades de maior uso 
na ëpoca.

\subsubsection{Levantamentos de infestação final}

Para este fim utilizaram-se os mesmos levin tamentos descritos em 3.1.1. Porém, os dados foram agruli dos em função das variedades amostradas nestas safras de 1977 a 1981. Para as comparaçõcs estatísticas considerì ram-se somente aquelas variedades amostradas no mínimo (m) 4 locais ou Usinas.

Adicionalmente, efetuou-se um cstudo compla rativo com 4 variedades de cana: CB40-13, IAC.52/150, CB47-355 e SP70-1499. Normalmente, as mais infestadas são as 2 pri meiras variedades. Para esse fim, foram plantadas essas variedades num mesmo talhão da CTEJ, em 08/04/78. Quinze meses após colheu-se a caná, sendo então cfetuados os 10 vantamentos de infestação final, conforme descrito em 3.1.1.

\subsubsection{Levantamentos populacionais}

Utilizaram-se os levantamentos descritos cm 3.1.2, nos canaviais comerciais das Usinas Barra Cirande de Lençōis Paulista, Santa Luiza de Matão e Santa Cruz S.^.de Capivari, durante o ano de 1981. Porém, os dados foram agrupados em função das variedades amostradas.

Tambẻm foram efetuados estes lcvantamentos no estudo comparativo de 4 variedades na CTEJ, citado em 3.3.1. Os levantamentos foram realizados em janciro c fevereiro de 1979, quando as canas estavam com 9 c 10 meses de cros cimento.

Os procedimentos posteriores foram semelhan tes àqueles descritós $\mathrm{cm} 3.1 .2$. 
3.3.3. Testes de controle natural de ovos da brocia

Efetuaram-sc 9 testes sequenciais no estulo comparativo de 4 variedades na CTEJ, citado anteriormente, seguindo a metodologia descrita em 3.1.3. Os testes foram efetuados mensalmente no período compreendido entre 28/09/ 178 a 29/06/79, quando as canas estavam com 5,5 a 14,5 me ses de crescimento. Nos primeiros 8 testes utilizaram-so 10 posturas por variedade, enquanto que no ültimo usaram-se 5 posturas por variedade.

3.3.4. Testes de sobrcvivência e duração do ciclo biológico

Num primeiro estudo compararam-se as variedal des NA56-79 e IAC48-65, em condições de telado, localiza do na Estação Experimental de Sertãozinho do Centro de Tecnologia Copersucar (CTES) . Para esse fim plantarall-sc 4 sulcos de $3,5 \mathrm{~m}$ de cada variedade em 08/09/78. Posterior mente, entre 2,5 e 8,0 meses de crescimento da cana, in festaram-se em 3 datas $(21 / 11 / 78,24 / 01 / 79$ e 02/03/79) com nümero conhecido de larvas recëm éclodidas.

A cana foi cortada em $09 / 04 / 79$ e no segundo ciclo vegetativo (soca) repetiram-se 3 infestações $(\mathrm{cm}$ $11 / 07 / 79,16 / 08 / 79$ e 11/10/79) com número conhecido de larvas recém eclodidas, quando as canas estavam com 3 a 8 meses. A metodologia posterior foi semelhante $\bar{a}$ descriti em 3.1 .4 .

Um segundo estudó foi conduzido cm canilvialis comerciais de 19 corte da Usina Barra ciande, comparando as variedades CB41-76 e NA56-79. Efetuaram-se 2 testes: um em outubro-77 e outro em janeiro-78, quando as callas 
estavam com 7 e 9 meses de crescimento.

Outra sêrie de 8 testes foi conduzida no es tudo comparativo de 4 variedades instalada na CTEJ, citado em 3.3.1. Os testes efetuaram-se no período de setembro-78 a março-79, quando a cana estava com 5 a 11 meses de cres cimento.

0 procedimento posterior foi semelhante ilyuc 1e descrito em 3.1.4.

3.3.5. Testes sobre capacidade reprodutiva de D. saccharalis

Os testes foram completados apenas no estudo comparativo de 4 variedades, instalado na CTEJ, citado cm 3.3.1. Foram realizados 6 testes, utilizando-se das cole tas maciças nas 4 variedades, no período janeiro-março de 1979. O procedimento posterior foi semelhante àquele de $\underline{s}$ crito em 3.1 .5 .

3.4. Estado nutricional da canea

A influência deste fator na infestação da broca foi estudada em diversos experimentos e testes de adubação ou fertilização da cana.

3.4.1. Levantamentos de infestação final

Conforme a metodologia descrita em 3.1 .1 , ro ram realizados levantamentos de infestaço final nos se guintes experimentos c/ou estudos. 
Usinas São Geraldo (Sertãozinho, SP) e Santa luiza (Matão, $\mathrm{SP})$, com doses crescentes dos 3 macronutrientes $(\mathrm{N}, \mathrm{P}, \mathrm{K}) \mathrm{cm}$ cana de 29 corte, variedade NA56-79. Os levantamentos ro ram efetuados durante a colheita, em julho de 1978, atri vês da amostragem de 10 canas por parcela, somando um to tal de 60 canas examinadas para cada tratamento.

Um canavial comercial da Usina São José . ZI, (Macatuba, SP), localizado na Fazenda Santo $\Lambda$ ntonio, roi dividido para receber adubações diferenciadas de Nitrogê nio $(100 \mathrm{~kg} / \mathrm{ha}$ de uréia), e Potāssio $(200 \mathrm{~kg} / \mathrm{ha}$ de clorcto de potássio), além da testemunha absoluta (sem adubacióo alguma). 0 canavial foi plantado com a varicdade I $\Lambda$ C.52/150 em $03 / 04 / 77$ e colhido em maio-78, com 13 meses de cresc mento; quando foram realizados os levantamentos de infes tação final, amostrando-se 100 canas por tratamento.

Outro canavial plantado especificamente para este estudo, na Fazenda Patos da Usina São José ZL, com a variedade NA56-79, foi dividido para reccber adubaçõcs di ferenciadas de Fósforo (120 kg/ha de super triplo), Potās sio $(200 \mathrm{~kg} / \mathrm{ha}$ de cloreto de potāssio), Nitrogênio (10) $\mathrm{kg} / \mathrm{ha}$ de uréia), Silício ( $6 \mathrm{~kg} / \mathrm{ha}$ de metassilicato de sỏdio), Cä1 cio $(200 \mathrm{~kg} / \mathrm{ha}$ de cloreto de cálcio) e $Z$ inco $(3 \mathrm{~kg} / \mathrm{hal}$ de sulfato de zinco), além da testemunha absoluta ( $\mathrm{scm}$ aduba cão alguma). 0 canavial foi plantado em 22/04/78 e colhiclo em maio-79, com 13 meses de crescimento, quando foram re $\underline{i}$ tos os levantamentos de infestação final, amostrando-sc 200 canas por tratamento.

\subsubsection{Levantamentos populacionat is}

Três desses levantamentos foram completalos nos canaviais adubados diferencialmente na Fazenda patos 
d̆a Üina São Jöse̋ $Z L$, descritós em 3.4.1. Os 1evantamentos foram realizados em $21 / 11 / 78,14 / 12 / 78$ e 17/01/79, ou sejil, quando a cana estava aproximadamente com 7, 8 e 9 meses de crescimento, medindo-se a ärea de coleta que permitiu cal cular a densidade populacional por ha. Posteriormente, o material coletado foi processado conforme descrito em 3.1.2.

3.4.3. Testes de controle natural de ovos da brocil

Os testes foram conduzidos conforme a metollo logia descrita em $3 \cdot 1.3$.

Uma sêrie de 2 testes foi conduzido $\mathrm{cm} 2$ i⿺ naviais da Usina São Jose $\mathrm{ZL}$, plantados com a variclade NA56-79. Um desses canaviais, plantado em outubro-77 nil lia zenda Sede, lote 14-08, moṣtrou comparativamente baixos teores de nutrientes, especialmente $\mathrm{N}, \mathrm{K}, \mathrm{Fc}$ e Mn. $\mathrm{O}$ outro canavial, plantado em dezembro-77 na Fazenda Pouso $\Lambda 1$ ggrc, lote 06-05, apresentou, comparativamente, altos teores de nutrientes, segundo anālises efetuadas no laboratōrio dia própria Usina. Portanto, o primeiro foi qualificado sim plesmente como canavial de "baixa' fertilidade", senclo o segundo chamado de "alta fertilidade", para fins comparat vos. Os testes de controle natural de ovos foram cxecutil dos em março-78, utilizando-se um total de 16 posturas em cada canavial.

Um reste foi realizado nos canaviais acluha dos diferencialmente, com Nitrogênio c potássio, na fiacen da Santo Antonio da Usina São Josẽ ZL, citado em 3.4.1. 11t lizaram-se 10 posturas por tratamento, expostas cm janci ro-78, 9 meses após o plantio da cana.

Outros 2 testes foram conduzidos nos cani 
viais adubados diferencialmente com N, P, K, Ca, Si c Zu, na Fazenda Patos da Usina São Josẽ ZL, citados em 3.4.1.0s testes foram realizados em outubro a dezembro de 1978, ut lizando-se um total de 10 posturas por tratamento.

\subsubsection{Testes de sobrevivência e duração do ciclo biológico}

Os testes citados a seguir foram descrivolv dos seguindo a metodologia descrita em 3.1.4.

Dois testes foram conduzidos nos canaviais adubados diferencialmente com Nitrogênio e Potássio, ni lä zenda Santo Antonio da Usina São Josẽ ZJ, descritos em 3.4.1. Noventa larvas recém eclodidas foram colocadas cm $11 / 11 / 77$, em 30 colmos por tratamento ( 3 brocas por colmo) e outras 90 em 20/12/77, ou seja, quando a cana cstavil com 7,0 e 8,5 meses de crescimento, aproximadamentc.

Seis testes foram completados em canaviais adubados diferencialmente com $\mathrm{N}, \mathrm{P}, \mathrm{K}, \mathrm{Ca}, \mathrm{Si}$ e $\mathrm{Zn}$ na lia zenda Patos da Usina São José ZL, descritos $\mathrm{cm} \mathrm{3.4.1,} \mathrm{Cin}$ co touceiras de cana por tratamento foram "inoculadas" com 100 brocas recém eclodidas nas seguintes datas: 21/09/78, $18 / 10 / 78,14 / 11 / 78,22 / 11 / 78,23 / 12 / 78$ e 06/01/79, comple tando assim 600 brocas "inoculadas" por tratamento.

Outros 5 testes foram conduzidos em um can $\underline{a}$ vial comercial da variedade IAC52-150 da Usina São José Zl, localizado na Fazenda Santo Antonio, Lote 04-02. Uma par te do canavial, após o primeiro corte cm junho-78, foi li vidido para receber as adubações diferenciadas de Nitrogê nio $(100 \mathrm{~kg} / \mathrm{ha}$ de Uréia), Potāssio $(200 \mathrm{~kg} / \mathrm{ha}$ de C1orcto de Potăssio), Fósforo (120 kg/ha de super triplo), Silicio 
(6. $\mathrm{kg} / \mathrm{ha} \cdot \mathrm{de}$ metassilicato de sôdio), Cålcio $(200 \mathrm{~kg} / \mathrm{ha}$ de Cloreto de Cảlcio), e Zinco ( $3 \mathrm{~kg} / \mathrm{ha}$ de Sulfato de Zinco), alèm da testemunha absoluta. Os testes foram desenvolvi dos nessas parcelas, infestando-se 5 touceiras de cana por tratamento com 100 brocas recêm eclodidas, nas seguintes datas: $28 / 10 / 78,21 / 11 / 78,07 / 12 / 78,05 / 01 / 79$ c 17/01/79, totalizando assim 500 brocas "inoculadas" por tratamento.

Outro estudo foi conduzido em condições de telado, localizado na CTES. Para esse fim, plantaram-se 8 sulcos de 3,5m, com a variedade CB41-76 em 08/09/78. Dois sulcos foram adubados com Nitrogênio $(40 \mathrm{~g}$ de sulfato do amônia), 2 com Fởsforo $(230 \mathrm{~g}$ de superfosrato simples), c outros 2 com Potássio (40 g de cloreto de potássio). İm $21 / 11 / 78,24 / 01 / 79$ e 02/03/79 infestaram-se as canas de ca da tratamento com um total de 404 brocas recém eclodidas na Testemunha, 408 no Nitrógênio, 399 no Fósforo e 402 no Potåssio.

A cana foi cortada em 09/04/79 e adubada no vamente em 24/05/79. No segundo ciclo vegetativo (soca), efetuaram-se 3 novos testes de sobrcvivência e duração do cic1o biológico em $11 / 07 / 79,16 / 08 / 79$ e $11 / 10 / 79$ com as mesmas quantidades de brocas recém eclodidas usadas no ci c1o anterior. Os procedimentos foram os mesmos descritos em 3.1 .4 .

3.4.5. Testes sobre capacidade reprodutiva de 0 . saccharalis

Os testes foram conduzidos scguindo al metodo logia descrita em 3.1 .5 , utilizando-sc o material biolo gico coletado nos estudos mencionados a seguir. 
Para as parcelas adubadas diferencialimente com $\mathrm{N}$ e K, além da testemunha, na Fazenda Santo Antonio da Usina São José ZL, descrita em 3.4.1., os testes foram com pletados no laboratório em fevereiro-março de 1978.

Outros testes foram completados

utilizin do-se as coletas de 2 canaviais de fertilidades diferencia das (uma com baixa e outra com alta fertilidade), local i zados nas fazendas Sede e Pouso Alegre da Usina São Jose Zl, e que foram descritas em 3.4.3. Os testes de 1aboratório foram realizados em abril-78.

Tambêm foram usadas as colctas dos lotes. de cana adubadas diferencialmente com $\mathrm{P}, \mathrm{K}, \mathrm{N}, \mathrm{Si}, \mathrm{Ca}, \mathrm{Zn}$ nil Fazenda Patos da Usina São José ZL, descritas em 3.4.1. () testes de laboratório foram realizados no período de dezcm bro-78 a fevereiro-79.

\subsection{Efeito da aplicação de vinhaça}

A aplicação deste subproduto da indústria alcoo leira ê uma prātica que vem se firmando definitivamente, pois tem efeitos nutricionais e de irrigação nos canaviais aplicados. E de se esperar que essa prätica tenha também alguma influência no desenvolvimento da broca e de scus inimigos naturais. Por isso, foi pesquisada a sua influçn cia em canaviais comerciais e experimentais através dos seguintes estudos:

3.5.1. Levantamentos de infestação final

Os levantamentos de campo foram realizalios conforme a metodologia descrita $\mathrm{cm} 3.1 .1$. 
Num primeiro estudo compararam-se as infestâ ções em canaviais comerciais da Usina São João ( $\Lambda$ raras, Sl) abrangendo as Fazendas São João, Jardim e Boa Vista, onde uma parte estava recebendo vinhaça diluída (com águas resi duais da indústria na proporção de 1:10) por infiltraçio, atravês de canais de irrigação, descle 1975. lim média, apli caram-se $2.350 \mathrm{~m}^{3} /$ ha da mistura, equivalente a $235 \mathrm{~m}^{3}$ de $\mathrm{v} \underline{\mathrm{i}}$ nhaça, com um conteüdo estimado em $233 \mathrm{~kg} / \mathrm{ha}$ de $\mathrm{N}, 35 \mathrm{~kg} / \mathrm{hil}$ de $\mathrm{P}_{2} \mathrm{O}_{5}$, e $1133 \mathrm{~kg} / \mathrm{ha}$ de $\mathrm{K}_{2} \mathrm{O}$. As infestações registralas nesses canaviais, durante as colheitas de 1976, 1977 c 1978 foram confrontadas com as infestações registradas no resto dos canaviais, nas mesmas áreas (próximas à inclús tria de ảlcool e açücar)。

Estes levantamentos foram tambëm realizados durante a colheita de 2 experimentos instalados por tercei ros para fins de nutrição mineral combinando a aplicação de vinhaça de mosto misto (rico em potảssio), nas dosagens de $40,80,120,160$ e $200 \mathrm{~m}^{3} / \mathrm{ha}$, com e sem complementacia de adubação fosfatada-nitrogenada. Um experimento estava instalado em talhão comercial da Usina São Carlos (Jaboti cabal, SP) ressoca (30 corte) da variedade CB41-76, em so 10 LRd。 0 outro experimento estava instalado em talhão co mercial da Usina Santa Adelaide (Dois Cörregos, SP) soca (29 corte) da variedade NA56-79, em solo LVa. Os experimen tos estavam instalados em blocos ao acaso, com 12 tratamen tos e 3 repetições. As parcelas eram compostas de 8 sulcos de $30 \mathrm{~m}$ de comprimento; espaçados a $1,5 \mathrm{~m}$. $\Lambda$ complementą ção da vinhaça com fertilizante mincral NP foi calculada em função da composição das vinhaças, procurando igualí-la às adubações minerais que foram $550 \mathrm{~kg} / \mathrm{ha} \mathrm{da}$

fórmula 12 - 06 - 12 na Usina São Carlos, c $500 \mathrm{~kg} / \mathrm{ha}$ ăa fórmila 14 - 07 - 28 na Usina Santa $\Lambda d e l a i d e . ~ \Lambda$ vinhaça foi apli

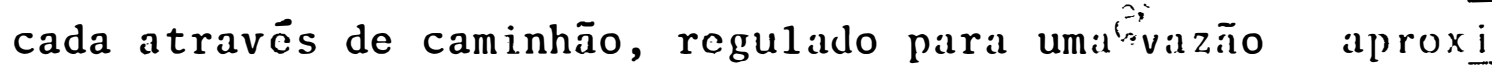


mada de $40 \mathrm{~m}^{3} / \mathrm{ha}$, variando apenas o nümero de aplicacoõcs nas parcelas para atingir as outras dosagens estudadis. Os tratamentos com complementação de adubação NP, foram misturados no próprio caminhão. Para os levantamentos de infestação final, amostraram-se 30 canas por parcela, total $\underline{i}$ zando assim 90 canas examinadas em cada tratamento, por cx perimento.

Paralelamente ao experimento anterior dil 11 i na São Carlos foi instalado outro em 1978, em cana planti (10 corte). Desta forma, colheram-se 2 experimentos cm 1979: um em cana de quarto corte e outro em cana de pri meiro corte, com a mesma variedade: CB41-76. O primciro cor responde ao descrito no parágrafo anterior, com aplicicócs acumuladas de vinhaça, e o segundo a outro montado cm 1978, sobre cana de 1 o corte. Neste último comparou-se uma tcste munha com 3 doses de vinhaça de mosto misto $(40,80$ e 120 $\left.\mathrm{m}^{3} / \mathrm{ha}\right)$, aplicados por caminhão pressurisado, como descr $\underline{i}$ to anteriormente. Nos levantamentos de infestação final amostraram-se 50 canas por parcela, totalizando assim 150 canas examinadas em cada tratamento, por experimento.

Um outro estudo foi realizado comparando 2 canaviais comerciais vizinhos, na Fazenda 21, Lote 57 da Usina Barra Grande de Lençōis Paulista, SP, plantados cm 1977 com a variedade NA56-79. Um desses talhões reccbcu vinhaça, a partir de 1978 (após o 1 e corte), na dose cst mada em $74 \mathrm{~m}^{3} / \mathrm{ha}$, através de caminhão. A mesma dose roi repetida em 1979, após o 2 9 corte. Portanto, comparou-sc esse talhão com o vizinho que não recebcu vinhaça cm toclo esse período. Ao final desses 2 anos, durante a colheita da cana ressoca ( 39 cortc) em 1980 , efetuaram-sc os levan tamentos de infestação final, amostrando-sc 200 canas cm cada ta1hão. 


\subsubsection{Levantamentos populacionais}

Os levantamentos foram efetuados conforme a metodologia descrita em 3.1.2, utilizando-se os 2 talhões comerciais pareados da Usina Barra Grande, mencionados c descritos em 3.5.1. Para esse fim coletaram-se as formals imaturas da broca, em cana ressoca, nas seguintes datas: $19 / 10 / 79,23 / 11 / 79,04 / 01 / 80,05 / 02 / 80$ e 13/03/80, ou se ja, quando a cana estava com $3,4,5^{1 / 2}, 6^{1 / 2}$, e $7^{1 / 2}$ me ses de crescimento aproximadamente.

3.5.3. Testes de controle natural de ovos da brocia

Três desses testes foram completados nos 2 talhões comerciais da Usina Barra Grande, descritos cm 3.5.1. Os procedimentos foram aqueles descritos em 3.1.3. Os testes foram instalados em 27/10/79, 07/12/79 e 14/01/80, utilizando-se 8,10 e 10 posturas por tratamento, respectí vamente.

3.5.4. Testes sobre capacidade reprodutiva de 0 . saccharalis

Para este fim foi utilizado o material bio lógico coletado nos levantamentos populacionais (citados em 3.5.3), que permitiram completar 13 testes sobre capaci dade reprodutiva. Portanto, neste caso, compararam-se tam bẻm os 2 canaviais comerciais da Usina Barra Grande, citados em 3.5.1. Os testes de laboratório foram conduzidos em fevereiro e março de 1980 , conforme os procedimentos descritos em 3.1.5.

\subsection{Anālises estatisticas}


Ưilizaram-se díversos tipos destas anâliscs, conforme o tipo de levantamento ou teste. Para os levintil mentos de infestação final, em diversas idades do canavial. (3.1.1) efetuaram-se anālises de regressões polinomiais dos valores mëdios de intensidade de infestação (I.I.). $\Lambda$ sua significância estatística foi determinada através do teste $F$ 。

Os dados de densidade populacional relat ival e de parasitismo total dos levantamentos populacionais em canaviais de diversas idades (3.1.2) foram submetidos a anălises de regressões lineares, e sua significância cstal tística determinada pelo teste $t$.

Os valores de controle natural de ovos da broca em canaviais de idades diferentes (3.1.3), forani sub metidos à anālise não paramētrica de qui-quadraclo. listá mesma análise foi utilizada para os valores de sobrevivên cia (3.1.4) e viabilidade dos ovos (3.1.5) obtidos em cana viais de diferentes idades.

Os indices de intensidade de infestação $\mathrm{cm}$ canas de diferentes idade (3.2.1) foram submetidos it an i lise de regressão, determinando-se a significância cstiltís tica pelo teste $t$. 0 mesmo tratamento estatístico foi dado aos valores de densidade populacional relativa e de paras $\underline{i}$ tismo total em canas de diferentes idades (3.2.2).

Os dados de controle natural de ovos da bro ca em canas de deferentes idades (3.2.3) foram comparalos estatisticamente pelo testc não paramétrico de qui-qualdrą do. A mesma análise foi aplicada aos valoros de sobrevivôn cia da broca em canas de diferentes idades (3.2.4). 
Ó F́ndices de intensidade de infestação ri nal nas variedades de cana (3.3.1) foram transformados cm arc sen $\sqrt{\frac{T}{o}}$ para submetê-los à anālise de variância, verifí, cando-se a sua significância estatística pelo teste F. Tam bém foi calculado o intervalo de Confiança (IC) das mêdias ao nível de $5 \%$ de probabilidade, para classificar as varic dades em: Acima (S), Dentro (D) e Abaixo ( $\Lambda$ ) do IC. Por outro lado, os indices de intensidade de infestasão rinal das 4 variedades comparadas na CTEJ (3.3.1) foram submet das à anālise não paramétrica do qui-quadrado.

Os valores de parasitismo nos levantamentos populacionais das 4 variedades na CTEJ (3.3.2) foram tam bém comparadas estatisticamente pelo testc de qui-quadralo. Esse mesmo teste foi usado para comparar cstatisticamentc os valores de controle natural de ovos da broca (3.3.3), os valores de sobrevivência (3.3.4) e os valores de capacicla de reprodutiva (3.3.5) das variedades estudadas.

Os indices de intensidade de infestação nal dos experimentos com doses crescentes de NPK, nas. Usi nas São Geraldo e Santa Luiza (3.4.1) foram submetidas à anâlises de regressões polinomiais, verificando-se a sua significância estatística pelo teste F. Os índices de in tensidade de infestação fïnal dos outros canaviais sujei tos a adubação diferenciada (3.4.1) foram comparadas csta tisticamente pelo teste de qui-quadrado.

Os dados de densidade populacional relativa e de parasitismo (estes ültimos transformados $\mathrm{em}$ arc sen $\sqrt{g}$ ) obtidos em canaviais com adubação diferencial na Usina São José ZL (3.4.2) foram submetidos à análise de variân cia, considerando-se os valores das 3 épocas estudadis, verificando-se a sua significância através do tcstc $\mathrm{F}$. 
Os valores obtidös nos demais testes comparan do-se adubações da cana, ou seja, aqueles de controle nil tural de ovos da broca (3.4.3), de sobrevivência e duracão do ciclo biológico (3.4.4) e de capacidade reprodutiva (3.4.5), foram submetidas à análise não paramétrica do quiquadrado.

0 teste não paramêtrico de Wilcoxon foi util $\underline{i}$ zado para verificar a significância estatisticia dos inclices de intensidade de infestação final em canaviais com e sem irrigação de vinhaça, na Usina São João (3.5.1). Este teste foi também utilizado para comparar os valores da densidalc populacional relativa e parasitismo obtidos nos levantamen tos populacionais dos 2 canaviais comerciais parcalos, com e sem vinhaça, na Usina Barra Grande (3.5.2).

Os indices de intensidade de infestação linal dos experimentos com doses crescentes de vinhaça nas Usinas São Carlos e Santa Adelaide (3.5.1) foram submetidos à anâa lises de regressões polinomiais, verificando-se a sua sign $\underline{i}$ ficação estatística pelo teste F.

0 teste não paramétrico de qui-quadrado loi utilizado para comparar os resultados obtidos nos 2 ciani viais pareados (com e sem aplicação de vinhaça) da Usina Barra Grande. Os valores comparados foram aqueles de inten sidade de infestação final (3.5.1), de controle natural de ovos da broca (3.5.3) e da sua capacidade reprodutiva(3.5.4). 


\section{RESULTADOS}

4.1. Idade do canavial

4.1.1. Levantamentos de infestação final de Diatraca saccharalis (Fabr., 1794)

Os valores médios de Intensidade de Infestação final de

D. saccharalis estão resumidos na Tabela 1 , sendo que no apêndice I estão relacionados alguns detalhes desses rosul tados.

Tabela 1. Intensidade de Infestação (I.I.) média causada pe la broca em canaviais de diferentes idades, no l:s tado de São Paulo. 1977-81

\begin{tabular}{crrrrr}
\hline Corte & 1977 & 1978 & 1979 & 1980 & 1981 \\
\hline 19 & 13,13 & 11,21 & 11,31 & 13,04 & 9,94 \\
29 & 11,45 & 7,52 & 7,78 & 10,31 & 8,02 \\
39 & 10,51 & 6,23 & 5,76 & 8,34 & 6,48 \\
49 & 10,69 & 5,36 & 5,84 & 6,92 & 6,27 \\
59 & 11,72 & 6,30 & 4,79 & 6,95 & 5,38 \\
69 & 8,45 & 7,95 & 5,86 & 6,52 & 3,71 \\
79 & 5,78 & 4,87 & 3,90 & 7,38 & 5,61 \\
89 & & 1,46 & 1,57 & 5,16 & 6,68 \\
\hline
\end{tabular}


As anălises de regressões polinomiais desses dados estão ilustrados na Figura 5 , sendo obtida significância estat ís tica ao nivel de 58 de probabilidade para os anos de 1977, 1978 e 1981, e ao nível de 18 para os anos de 1979 e 1980 , segundo o teste F.

\subsubsection{Levantamentos populaciona is}

Os resultados desses levantamentos $\mathrm{cm}$ funcĩo da idade dos canaviais amostrados em 3 Usinas do Estado de Șão Paulo, estão resumidos nas Tabelas 2,3 e 4 .

Tabela 2 . Densidade populacional relativa (coleta por ho ra/homem) e parasitismo da broca em canaviais de diferentes idades, na Usina Barra Grande, Sp, em 1981

\begin{tabular}{lccccc}
\hline \multirow{2}{*}{$\begin{array}{l}\text { Corte } \\
\text { (idade do } \\
\text { Canavial) }\end{array}$} & $\begin{array}{c}\text { Densidade } \\
\text { populacional } \\
\text { relativa }\end{array}$ & $\begin{array}{c}\text { M. mi } \\
\text { nense }\end{array}$ & $\begin{array}{c}\text { P. clari } \\
\text { palpis }\end{array}$ & $\begin{array}{c}\text { Braco } \\
\text { nídcos }\end{array}$ & Tota1 \\
\hline 1ạ (planta) & 19,5 & 17,0 & 11,1 & 0,4 & 28,5 \\
2ạ (soca) & 14,2 & 26,2 & 15,2 & 0,5 & 41,9 \\
$3 a$ (ressoca) & 17,6 & 27,6 & 10,1 & 0,1 & 37,8 \\
4ạ (ressoca) & 16,0 & 28,8 & 15,1 & 0,2 & 44,1 \\
$5 a$ (ressoca) & 14,0 & 30,6 & 9,6 & 0,0 & 40,2 \\
\hline
\end{tabular}




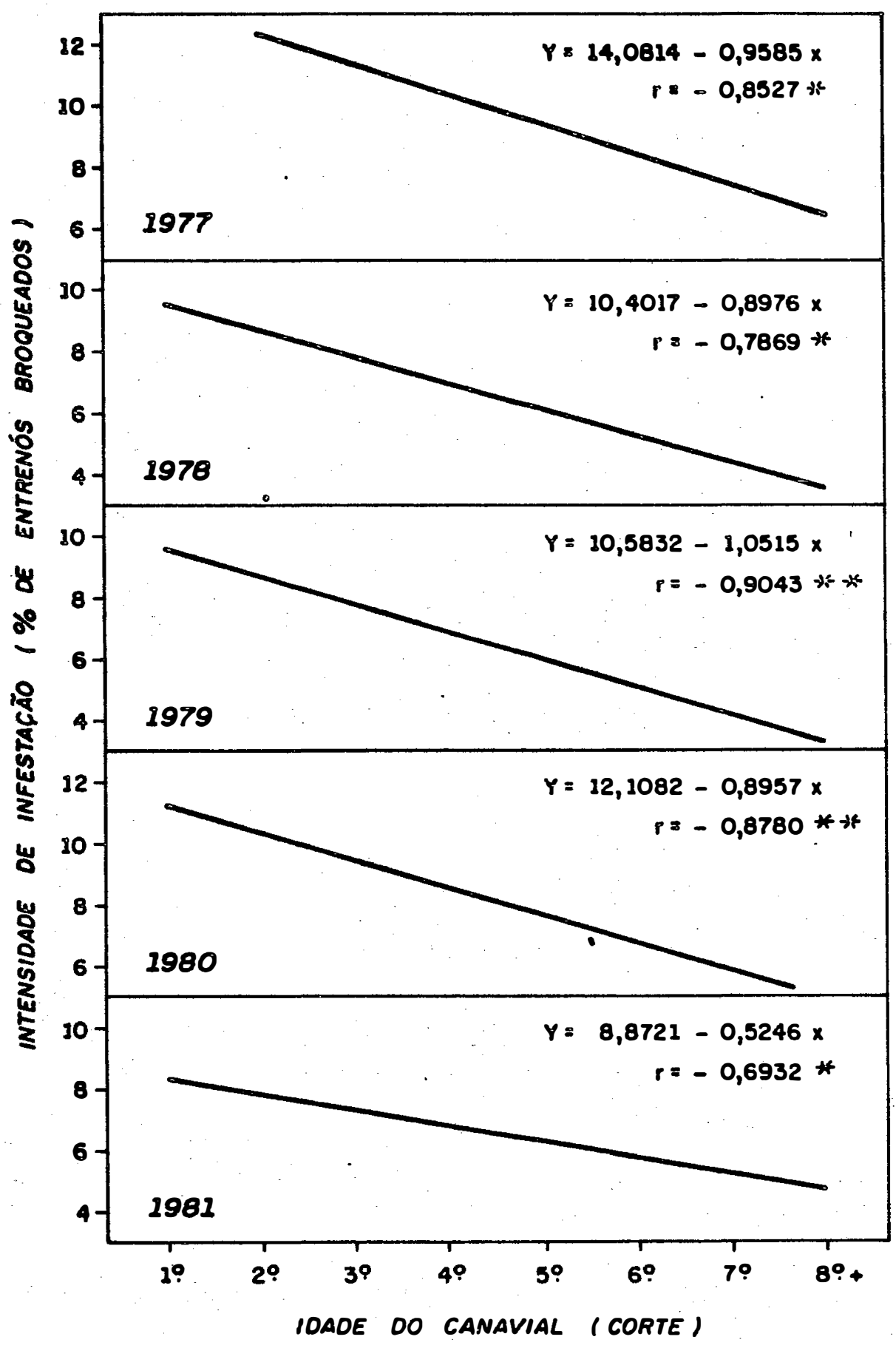

Figuro 5. Correloção entre idode do conovial (corte) e infestoço pela broco. 1977 ò 1981 . 
Tabela 3. Densidade populacional relativa (coleta por hora/ /homem) e parasitismo da broca em canaviais de di ferentes idades na Usina Santa Luiza, SP, em 1981.

\begin{tabular}{|c|c|c|c|c|c|}
\hline \multirow{2}{*}{$\begin{array}{l}\text { Corte } \\
\text { (idade do } \\
\text { canavial) }\end{array}$} & \multirow{2}{*}{$\begin{array}{l}\text { Densidade } \\
\text { populacional } \\
\text { relativa }\end{array}$} & \multicolumn{4}{|c|}{$\because$ Parasitismo } \\
\hline & & $\begin{array}{l}\text { M. mi } \\
\text { nense }\end{array}$ & $\begin{array}{l}\text { P. clari } \\
\text { palpis }\end{array}$ & $\begin{array}{l}\text { Bracoo } \\
\text { nídeos }\end{array}$ & Total \\
\hline 19 (planta) & 13,7 & 18,2 & 18,3 & 0,2 & 36,7 \\
\hline 29 (soca) & 12,9 & 16,7 & 19,0 & 0,0 & 35,7 \\
\hline 30 (ressoca) & 11,7 & 17,5 & 20,1 & 0,1 & 37,7 \\
\hline 49 (ressoca) & 10,7 & 8,5 & 15,9 & 0,0 & 24,4 \\
\hline
\end{tabular}

Tabe1a 4. Densidade populacional relativa (coleta por hora/ /homem) e parasitismo da broca em canaviais de diferentes idades na Usina Santa Cruz S.A., SP, em 1981

\begin{tabular}{lccccc}
\hline $\begin{array}{l}\text { Corte } \\
\text { (idade do } \\
\text { canavial) }\end{array}$ & $\begin{array}{c}\text { Densidade } \\
\text { populacional } \\
\text { relativa }\end{array}$ & \begin{tabular}{c} 
M. mi \\
\cline { 3 - 6 }
\end{tabular} & $\begin{array}{c}\text { P. clani } \\
\text { palpis }\end{array}$ & $\begin{array}{c}\text { Braco } \\
\text { nideos }\end{array}$ & Tota1 \\
\hline 19 (planta) & 13,7 & 36,0 & 0,6 & 4,4 & 41,0 \\
29 (soca) & 13,0 & 37,0 & 0,1 & 5,3 & 42,4 \\
39 (ressoca) & 12,6 & 38,4 & 0,1 & 4,8 & 43,3 \\
\hline
\end{tabular}

Em todoṣ os casos, houve uma tendência de di minuição da densidade populacional relativa com a idade do canavial (Figura 6). Porém houve significância estatística so mente nos dados da Usina Santa Luiza ao níve 1 de $1 \%$ de probal bilidade $\left(r=-0,9973^{* *}\right)$. Neste caso a correlação foi representada pela equação $Y=14,30-1,02 X$. Por outro 1ado, não houve sign $\underline{i}$ ficação estatística quando os dados de parasitismo total fo ram correlacionados com a idade do canavial (Figura 7). 


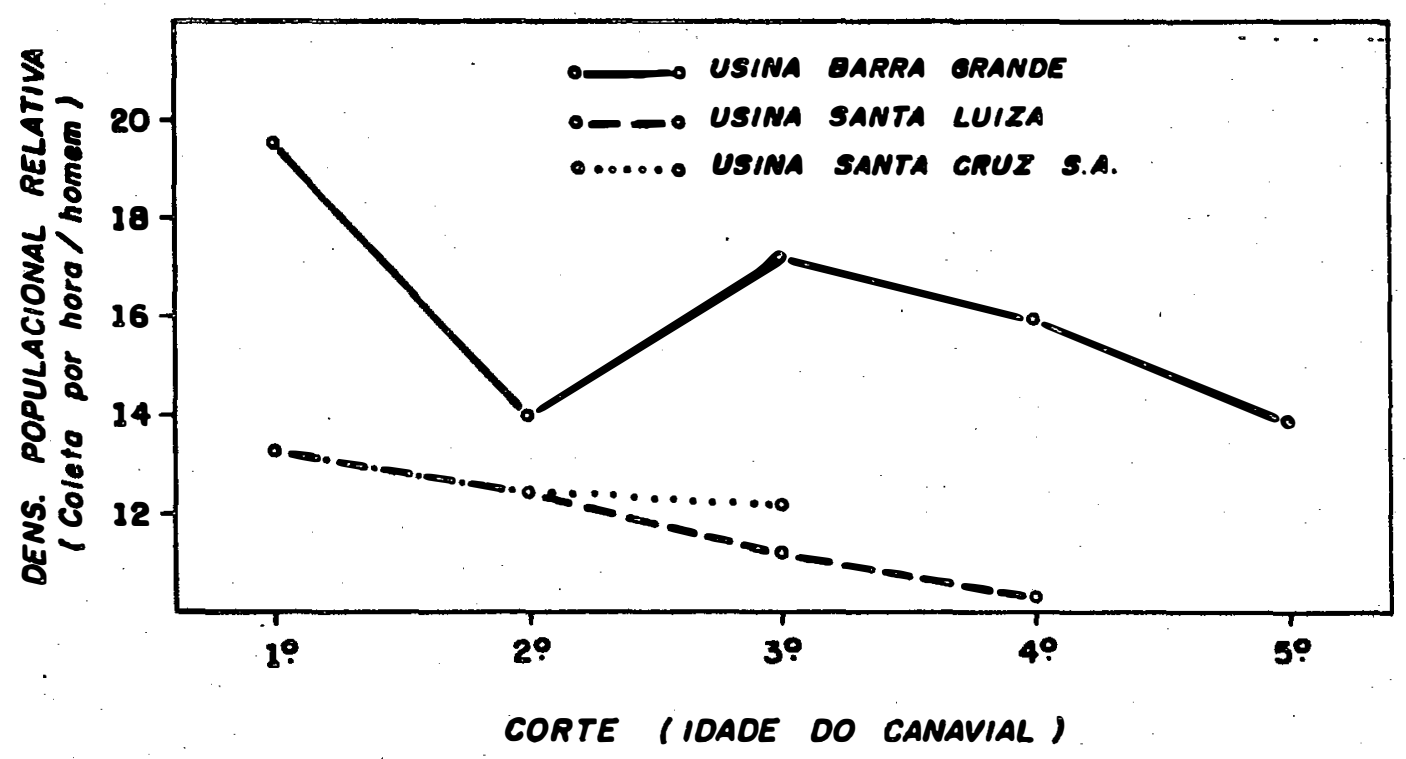

Figura 6. Reloção entre idade do conovial e densidade populacional da broca, em 3 usinas do Estado de São Poulo. 1981.

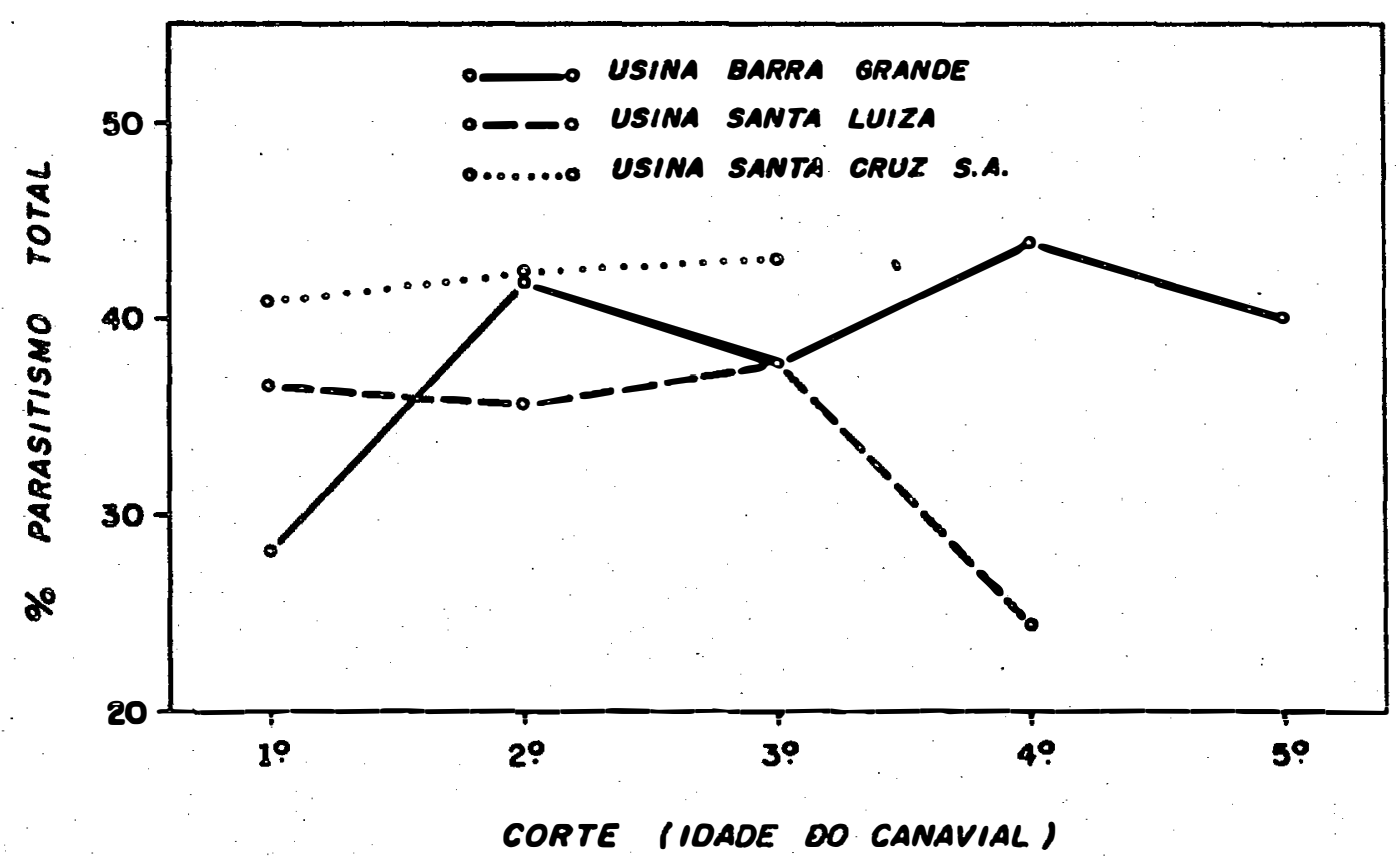

Figura 7. Relocão entre idade do conovial e parosi tismo total na broca, em 3 usinas do Está do de São Poulo. 1981. 
4.1.3. Testes de controle natural de ovos da brocil

Os resultados de oito testes efetuados nal CTr: estão resumidos na Tabela 5 .

Tabe1a 5. Controle natural (induzido) de ovos de D. saccharalis em 2 canaviais de diferentes idides, variedade IAC52-150. CTEJ, novembro-dezembro de 1978

\begin{tabular}{lccccc}
\hline $\begin{array}{l}\text { Corte } \\
\text { (idade do } \\
\text { canavia1) }\end{array}$ & $\begin{array}{c}\text { ovos } \\
\text { expostos }\end{array}$ & $\begin{array}{c}\text { paras } \mathbf{i} \\
\text { tados }\end{array}$ & $\begin{array}{c}\text { masti } \\
\text { gados }\end{array}$ & $\begin{array}{c}\text { suga } \\
\text { dos }\end{array}$ & $\begin{array}{c}\text { Controle } \\
\text { naturial } \\
\left(\begin{array}{l}o \\
0\end{array}\right)\end{array}$ \\
\hline 10 (planta) & 743 & 4,8 & 40,6 & 17,9 & 03,39 \\
49 (ressoca) & 735 & 3,4 & 55,5 & 10,7 & 69,66 \\
\hline
\end{tabular}

Qui-quadrado $=6,5174^{*}$

Na Tabela 6 estão comparados os resultialos de três testes realizados na Usina Barra Grande. 
Tabela 6. Controle natural (induzido) de ovos de 0 . saccharalis em 2 canaviais de diferentes idades, variedade NA56-79. Usina Barra Grande, SP. Sctem bro a novembro/78.

\begin{tabular}{|c|c|c|c|c|c|}
\hline \multirow{2}{*}{$\begin{array}{l}\text { Corte } \\
\text { (idade do } \\
\text { canavial) }\end{array}$} & \multirow{2}{*}{$\begin{array}{c}\text { ovos } \\
\text { expostos }\end{array}$} & \multicolumn{3}{|c|}{ a de ovos } & \multirow{2}{*}{$\begin{array}{c}\text { Cont rolc } \\
\text { natural } \\
\vdots\end{array}$} \\
\hline & & $\underset{\text { tados }}{\operatorname{paras}}$ & $\begin{array}{l}\operatorname{mast} i \\
\text { gados }\end{array}$ & $\underset{\cos }{\operatorname{sug}}$ & \\
\hline 19 (p1anta) & 255 & 2,7 & 40,4 & 18,0 & 01,18 \\
\hline 39 (ressoca) & 241 & 0,0 & 63,5 & 22,8 & 86,31 \\
\hline
\end{tabular}

Qui-quadrado $=40,0653 *$ *

Em ambos os casos verificou-se diferença esta ristica, sendo maior o controle natural em canaviais mals velhos. Verificou-se uma maior participação dos predadores mastigadores em todos os casos como controladores naturitis de D. saccharalis.
4.1.4. Testes de sobrevivência e duração do ciclo biológico

Os resultados dos 3 únicos testes complet $\underline{a}$ dos na Usina Barra Grande, em 2 canaviais de diferentes id des, com a variedade NA56-79, estão na Tabela 7. 
Tabela 7. Sobrevivếncia de 300 ovos no estágio "cabeşa pré ta", e duração do período larva + pupa de $D$. saccharalis, em 2 canaviais da variedale $N \Lambda 50-79$, com idades diferentes. Usina Barral Cirande, out bro-novembro/78

\begin{tabular}{|c|c|c|c|}
\hline \multirow{2}{*}{$\begin{array}{l}\text { Corte (idade } \\
\text { do canavial) }\end{array}$} & \multicolumn{2}{|c|}{ : sobrevivência de } & \multirow{2}{*}{$\begin{array}{l}\text { Duração mídiat } \\
\text { larva + pulat }\end{array}$} \\
\hline & pupas & adultos & \\
\hline 1o (planta) & 4,0 & 3,0 & 44,3 dias \\
\hline $39($ ressoca $)$ & 1,0 & 1,0 & 54,3 dias \\
\hline
\end{tabular}

Qui-quadrado $=3,0612$ n.s.

Não houve diferença estatística quando compla rados o número de adultos sobreviventes. No entanto, a d프 ração do período larva + pupa foi bem maior na cana de 3 o corte comparada com aquela na cana de 1 o cortc.

4.1.5. Testes sobre capacidade reprodutiva de 0 . saccharalis

Os resultados daqueles testes realizados n:i Usina São Josẽ ZL (Macatuba, SP) estão apresentados na lia be 1a 8 . 
Tabe12 8. Resultados de 8 testes sobre capacidade roprodut va de $D$. saccharalis, criada em canaviais da va riedade NA56-79 com 2 idades diferentes. Usina São Josē ZL, março/78.

\begin{tabular}{lcccc}
\hline $\begin{array}{l}\text { Corte } \\
\text { (idade do } \\
\text { canavia1) }\end{array}$ & $\begin{array}{c}\text { No } \\
\text { de } \\
\text { casais }\end{array}$ & ovos obtidos por \& & Viabilidiale \\
\cline { 3 - 5 } & total & viảveis & : \\
\hline 19 (planta) & 15 & 531,4 & 415,3 & 78,14 \\
49 (ressoca) & 9 & 418,5 & 273,0 & 65,22 \\
\hline
\end{tabular}

Qui-quadrado $=19,3494 * *$

Na Tabela 9 estão os resultados de 2 testes conduzidos na CTEJ.

Tabela 9. Resultados de 2 testes sobre capacidade reproduti va de $D$. saccharalis, criadas em canaviais parea dos da variedade IAC52/150 com 2 idades diferen tes. CTEJ, novembro/78 。

\begin{tabular}{|c|c|c|c|c|}
\hline \multirow{2}{*}{$\begin{array}{l}\text { Corte } \\
\text { (idade do } \\
\text { canavia1) }\end{array}$} & \multirow{2}{*}{$\begin{array}{c}\text { No } \\
\text { de } \\
\text { casais }\end{array}$} & \multicolumn{2}{|c|}{ ovos obtidos por 9} & \multirow{2}{*}{$\begin{array}{c}\text { Viabil idade } \\
\text { : }\end{array}$} \\
\hline & & total & viäveis & \\
\hline $10(p 1 a n t a)$ & 4 & 202,0 & 151,2 & 74,88 \\
\hline $4 !($ ressoca $)$ & 3 & 136,0 & 63,0 & 46,32 \\
\hline
\end{tabular}

Qui-quadrado $=28,2808^{* *}$

Em ambos os casos, houve clara diferencia tan to em termos de ovos por fêmea como na viabilidade desses 
ovos. A anälise de qui-quadrado indicou que a viabilidade foi maior para as brocas criadas em cana planta, nas duas variedades estudadas (NA56-79 e IAC52/150)。

\subsection{Idade da cana (estado fenológico)}

\subsubsection{Levantamentos de infestação final}

Os resultados de avaliação da influência da idade da cana, no momento da colheita, sobre a infestacio final pela broca, na Usina Barra Grande durante a colheita de 1979, estão expostos na Tabela 10 .

Tabela 10. Infestação final pela broca em canas de diferen tes idades de crescimento no momento do corte ou colheita de 1979, na Usina Barra Grande (Lençois Paulista, SP) 。

\begin{tabular}{|c|c|c|c|c|}
\hline \multirow{2}{*}{$\begin{array}{l}\text { Idade da cana } \\
\text { (crescimento) }\end{array}$} & \multirow{2}{*}{$\begin{array}{l}\text { Canas } \\
\text { amostradas }\end{array}$} & \multicolumn{2}{|c|}{ Total de entrenós } & \multirow{2}{*}{$\begin{array}{l}\because \text { entrenós } \\
\text { broqucados }\end{array}$} \\
\hline & & Examinados & Broqueados & \\
\hline 9 meses & 300 & 4.676 & 138 & 2,95 \\
\hline 10 meses & 6.600 & 99.2298 & 2.681 & 2,70 \\
\hline 11 meses & 16.800 & 273.445 & 12.207 & 4,46 \\
\hline 12 meses & 113.100 & 1.813 .934 & 81.574 & 4,49 \\
\hline 13 meses & 83.200 & 1.380 .346 & 69.844 & 5,05 \\
\hline 14 meses & 36.200 & 623.368 & 39.059 & 6,26 \\
\hline 15 meses & 12.600 & 240.133 & 13.648 & 5,68 \\
\hline 16 meses & 15.100 & 280.991 & 20.587 & 7,32 \\
\hline 17 meses & 21.200 & 422.086 & 24.348 & 8,13 \\
\hline 18 meses & 12.700 & 285.612 & 23.812 & $8, .33$ \\
\hline 19 meses & 7.900 & 179.068 & $20.364_{n-1}$ & 11,37 \\
\hline 20 meses & 1.800 & 44.063 & 4.384 & 9,94 \\
\hline 21 meses & 100 & 4.270 & 512 & 11,99 \\
\hline
\end{tabular}


Os valores de intensidade de infestação ( $\%$ de entrenôs brocados) submetidos à anảlise de régressão mostrâ ram uma correlação positiva altamente significativa com a idade da cana (Figura 8).

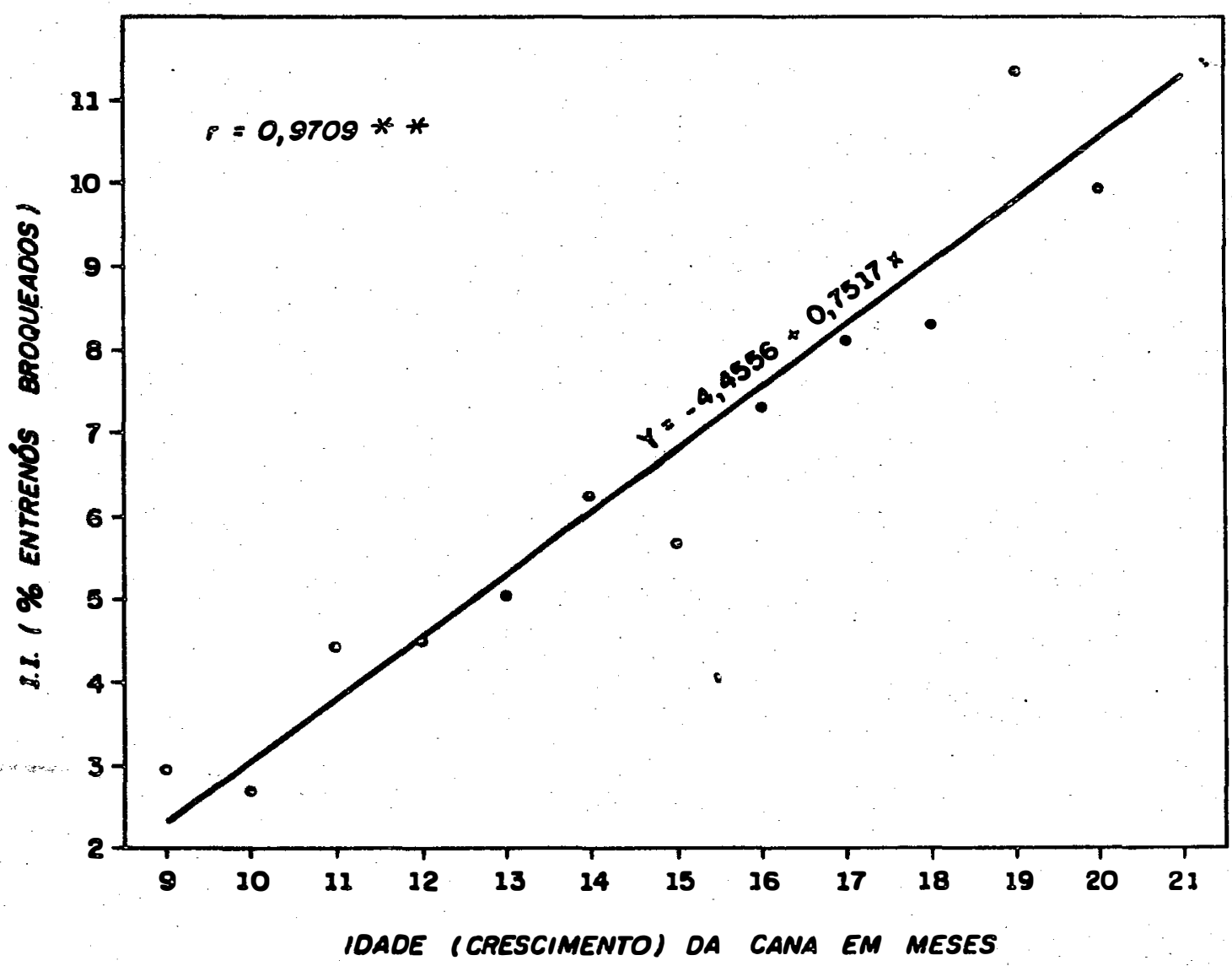

Figuro 8. Correlacão entre infestacõo final pela broca e idade da cano no momento da colheita. Usina Borro Gronde. 1979. 
4.2.2. Levantamentos populacionais

Nas Tabelas 11, 12 e 13 estão resumidos os re sultados desses levantamentos, efetuados nas 3 usinas repre sentativas, agrupadas em termos de idade das canas amostra das.

Tabela 11. Densidade populacional relativa (colcta por ho $\mathrm{ra} / \mathrm{homem)}$ e parasitismo da broca em canas de di ferentes idades de crescimento na Usina Barra Grande, SP, em 1981 .

\begin{tabular}{lccccc}
\hline \multirow{2}{*}{$\begin{array}{l}\text { Idade } \\
\text { da cana }\end{array}$} & $\begin{array}{c}\text { Densidade } \\
\text { populacional } \\
\text { relativa }\end{array}$ & $\begin{array}{c}\text { M. mi } \\
n \text { nens }\end{array}$ & $\begin{array}{c}\text { P. clari } \\
\text { palpis }\end{array}$ & $\begin{array}{c}\text { Braco } \\
\text { nídeos }\end{array}$ & Total \\
\hline 3 meses & 15,2 & 30,2 & 15,6 & 0,4 & 46,2 \\
4 meses & 19,2 & 30,8 & 19,3 & 0,4 & 50,5 \\
5 meses & 15,5 & 23,8 & 16,8 & 0,5 & 41,1 \\
6 meses & 14,2 & 20,9 & 13,3 & 0,3 & 34,5 \\
7 meses & 19,2 & 16,1 & 7,7 & 0,2 & 24,0 \\
8 meses & 21,1 & 15,4 & 06,4 & 0,4 & 22,2 \\
9 meses & 25,2 & 13,9 & 6,7 & 0,5 & 21,1 \\
10 meses & 28,0 & 17,1 & 8,3 & 0,1 & 25,5 \\
11 meses & 26,7 & 7,7 & 9,6 & 0,2 & 17,5 \\
\hline
\end{tabular}


Tabela 12. Densidade populacional relativa (coleta por ho ra/homem) e parasitismo da broca cm canas de di ferentes idades de crescimento na llsina sintil Luiza, SP, em 1981.

\begin{tabular}{lccccc}
\hline \multirow{2}{*}{$\begin{array}{l}\text { Idade } \\
\text { da cana }\end{array}$} & $\begin{array}{c}\text { Densidade } \\
\text { populacional } \\
\text { relativa }\end{array}$ & \begin{tabular}{c} 
M. mi \\
\cline { 3 - 6 }
\end{tabular} & $\begin{array}{c}\text { P. clari } \\
\text { palpis }\end{array}$ & $\begin{array}{c}\text { Braco } \\
\text { nideos }\end{array}$ & 'lotal \\
\hline 3 meses & 14,7 & 21,3 & 30,2 & 0,4 & 51,9 \\
4 meses & 14,1 & 25,5 & 14,4 & 0,1 & 40,0 \\
5 meses & 13,3 & 25,3 & 20,4 & 0,2 & 45,9 \\
6 meses & 10,1 & 17,7 & 17,9 & 0,0 & 35,6 \\
7 meses & 11,6 & 14,4 & 10,5 & 0,0 & 24,9 \\
8 meses & 12,7 & 12,1 & 21,7 & 0,1 & 33,9 \\
9 meses & 13,9 & 11,9 & 12,2 & 0,1 & 24,2 \\
10 meses & 12,2 & 16,4 & 24,0 & 0,0 & 40,4 \\
\hline
\end{tabular}

Tabela 13. Densidade populacional relativa (coleta por ho$\mathrm{ra/homem)} \mathrm{e} \mathrm{parasitismo} \mathrm{da} \mathrm{broca} \mathrm{em} \mathrm{canas} \mathrm{de} \mathrm{di}$ ferentes idades de crescimento na usina, Sinta Cruz S.A., SP, em 1981 .

\begin{tabular}{|c|c|c|c|c|c|}
\hline \multirow{2}{*}{$\begin{array}{l}\text { Idade } \\
\text { da cana }\end{array}$} & \multirow{2}{*}{$\begin{array}{l}\text { Densidade } \\
\text { populacional } \\
\text { relativa }\end{array}$} & \multicolumn{4}{|c|}{ : Parasitismo } \\
\hline & & $\begin{array}{l}\text { M. mi } \\
\text { nense }\end{array}$ & $\begin{array}{l}P_{\text {. clari }} \\
\text { palpis }\end{array}$ & $\begin{array}{l}\text { Braco } \\
\text { nídeos }\end{array}$ & Total 1 \\
\hline 3 meses & 13,7 & 49,6 & 0,8 & 2,2 & 52,6 \\
\hline 4 meses & 13,3 & 48,9 & 0,7 & 2,2 & 51,8 \\
\hline 5 meses & 16,1 & 41,4 & 0,2 & 2,0 & 43,6 \\
\hline 6 meses & 13,1 & 45,2 & 0,1 & 4,8 & 50,1 \\
\hline 7 meses & 11,8 & 38,4 & 0,4 & 6,1 & 44,9 \\
\hline 8 meses & 15,3 & 23,1 & 0,2 & 5,4 & 28,7 \\
\hline 9 meses & 17,8 & 30,8 & 0,2 & 5,6 & 36,6 \\
\hline 10 meses & 15,1 & 23,2 & 0,3 & $1.3,9$ & 37,4 \\
\hline
\end{tabular}




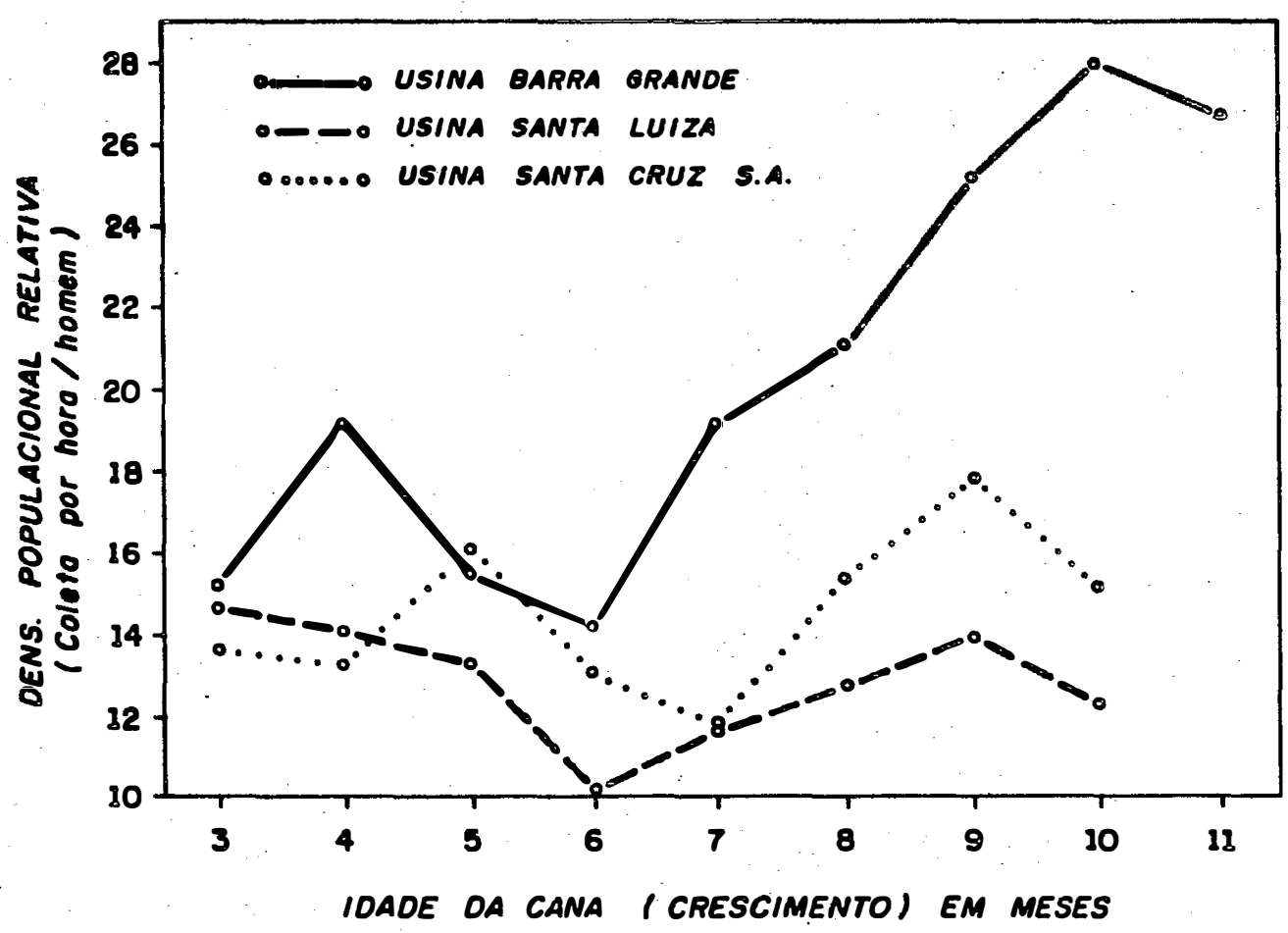

Figura 9. Relação entre idode da cana e densidade populacional da broca, em 3 usinas do Es todo de São Paulo. 1981.

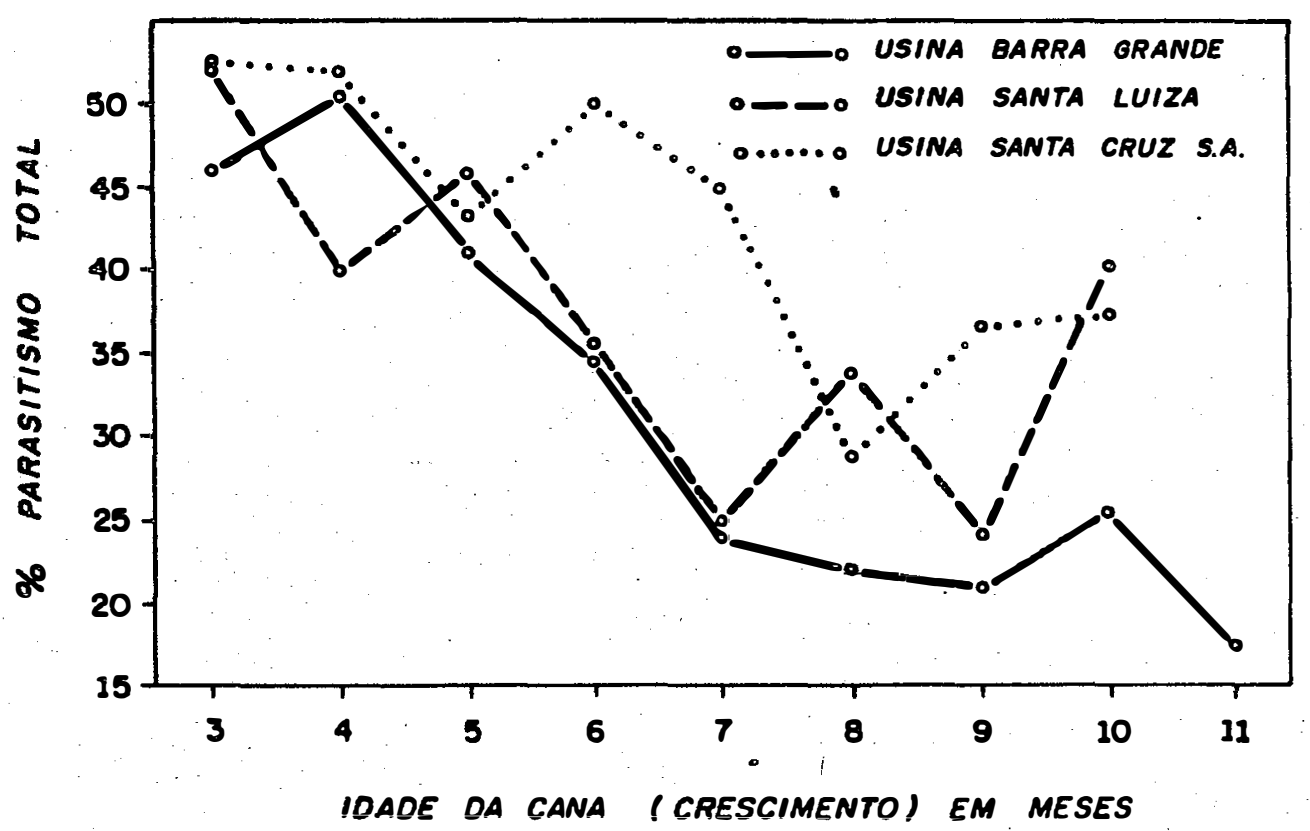

Figuro 10. Relacāo entre idade do cono e parasitismo total na broca em 3 usinas do Estado de Sāo Poulo. 1981. 
Os valores de densidade populacional relati va, submetidos à anālise de regressão, foram significativos ao níve 1 de $1 \%$ de probabilidade $\left(r=0,8725^{* *}\right)$ para alue les valores da Usina Barra Grande, representadi pela equa ção $Y=8,9628+1,6450 X$. Essa correlação não loi cviden te para os valores das Usinas Santa Luíza e Santa Cruz S.^., como pode ser observado na Figura 9.

O parasitismo total da broca decresceu signi ficativamente com o aumento da idade da cana para os villo res obtidos na Usina Barra Grande $\left(r=-0,9153^{* *}\right)$ e na Usi na Santa Cruz S.A. $\left(r=-0,8012^{*}\right)$. Nesses casos a correla ção negativa estã representada pelas equaçõos $Y=59,6450-4,0350 X$ e $Y=53,0559-2,4548 X$, respectiv $\underline{\text { a }}$ mente. Essa correlação não foi evidente para os valores da Usina Santa Luíza, como pode ser tambëm verificado na Figura 10 .

4.2.3. Testes de controle natural de ovos da broca

Os resultados de 3 testes efetuados na CTEJ em cana IAC52/150 de 39 corte, estão apresentados na Tibela 14, enquanto que os correspondentes ao teste na Usina Barra Grande em cana CB41-76 de 20 corte, estão apresentados na Tabela 15 .

Em ambos os casos, a anālise estatística foi significativa ao nível de $5_{0}^{\circ}$ de probabilidade, indicando que houve maior parasitismo e predação dos ovos nas canas milis velhas. 
Tabela 14 - Controle natural (induzido) de ovos de 0 . saccharalis em canas com diferentes idades de crescimento, num canavial de 39 corte IAC52/150. CTEJ, maio-ju1ho/78

\begin{tabular}{lccccc}
\hline $\begin{array}{l}\text { Idade } \\
\text { da } \\
\text { cana }\end{array}$ & $\begin{array}{c}\text { ovos } \\
\text { expostos }\end{array}$ & parasitados & mastigados & sugados & $\begin{array}{c}\text { controle } \\
\text { naturil }\end{array}$ \\
\cline { 4 - 6 } $\begin{array}{l}2-4 \text { meses } \\
\text { (pequena) }\end{array}$ & 333 & 2,1 & 47,4 & 10,5 & 60,06 \\
$\begin{array}{l}7-9 \text { meses } \\
\text { (grande) }\end{array}$ & 337 & 3,0 & 38,3 & 26,4 & 67,65 \\
\hline
\end{tabular}

Qui-quadrado $=4,1882$ *

Tabela 15 - Controle natural (induzido) de ovos de 0 . saccharalis em canas com diferentes idades de crescimento, num canavial de 20 corte CB41-76. Usina Barra Grande, outubro/78

\begin{tabular}{|c|c|c|c|c|c|}
\hline \multirow{2}{*}{$\begin{array}{l}\text { Idade } \\
\text { da } \\
\text { cana }\end{array}$} & \multirow{2}{*}{$\begin{array}{l}\text { ovos } \\
\text { expostos }\end{array}$} & \multicolumn{3}{|c|}{$\stackrel{0}{\circ}$ de ovos } & \multirow{2}{*}{$\begin{array}{c}\text { controlo } \\
\text { natural } \\
\substack{0 \\
0}\end{array}$} \\
\hline & & parasitados & mastigados & sugados & \\
\hline $\begin{array}{l}4 \text { meses } \\
\text { (pequena) }\end{array}$ & 80 & 11,2 & 45,0 & 0,0 & 56,25 \\
\hline $\begin{array}{l}11 \text { meses } \\
\text { (grande) }\end{array}$ & 81 & 13,6 & 40,7 & 17,3 & 71,60 \\
\hline
\end{tabular}

Qui-quadrado $=4,1174^{*}$ 

4.2.4. Testes de sobrevivência e duração do ciclo biológico

Na Tabela 16 estão resumiclos os dados de 2 tẹs tes executados na Ụsina Barra Brande.

Tabela 16 - Sobrevivência de 180 larvas recém eclodidas, e duração do período 1 arva + pupa de 0 . sacchatal'is, em canas com diferentes idales de crescimento, CB41-76, soca. Usina Barra Crande, 1977-78.

\begin{tabular}{lccc}
\hline $\begin{array}{l}\text { Idade } \\
\text { da cana }\end{array}$ & \begin{tabular}{c}
0 sobrevivência de \\
\cline { 2 - 3 } $\begin{array}{l}\text { pupas } \\
\text { (pequena) }\end{array}$
\end{tabular} & adultos & $\begin{array}{l}\text { Duração médial } \\
\text { larva }+ \text { pupa }\end{array}$ \\
$\begin{array}{l}11 \text { meses } \\
\text { (grande) }\end{array}$ & 5,0 & 2,2 & 53,7 dias \\
\hline
\end{tabular}

Qui-quadrado $=0,8439 \mathrm{n}$.s.

A anālise estatística dos valores de sobrevi vência não foi significativa, sendo que a duração do perío do larva + pupa também foi semelhante em canas grandes ou pequenas.

4.3. Variedades de cana

Os estudos comparativos sobre a influência das diversas variedades de cana na infestação e alguns as pectos bio-ecológicos da broca, ofereceram os seguintes re sultados. 
4.3.1. Levantamentos de infestação Tinàl

Os dados desses levantamentos em função das variedades de cana amostradas durante as safras de 1977 a 1981, estão relacionados no apêndice II. As anālises de va riância para tratamentos de diferente nümero de repetições, correspondentes aos valores médios de Intensidade de Inles tação, transformados em arc sen $\sqrt{o}_{0}^{T}$, revelaram que as diferenças não foram significativas para os valores dos anos 1977 e 1979.

Para os valores correspondentes a 1978, 1980 e 1981, a significância ao nível de 1\% de probabilidade, per mitiu comparar as variedades de cana conforme as relacoocs das Tabelas 17, 18 e 19, incluindo-se tambẻm a classifica ção das variedades pelo Intervalo de Confiança da média ao nível de 5\% de probabilidade (IC 5\%)。

Mẻdias seguidas da mesma letra não diferem es tatisticamente ao nível de 5\% de probabilidade (teste de Tukey).

As variedades IAC52/150, IAC 58/480, NA56-79, CP51-22 e IAC51/205 apresentaram infestações sempre acima da média quando comparadas pelo IC5\%, podendo ser considera das como variedades suscetiveis. Por outro lado, as varic dades CB47-355, CB49-62, IAC50/134, Co740, Co775 e IAC48/65 apresentaram infestações sempre abaixo da média, sendo por tanto consideradas como variedades resistentes.

A infestação levañtada nas 4 variedades de cana comparadas na CTEJ, está relacionada na l'abcla 20 . 
Tabela 17. Mẻdias de Intensidade de Infestação (I.I.) por D. saccharalis em variedades de canals amostradas em 1978, comparadas pelo teste Tukey e pelo In tervalo de Confiança da média a $5 \%$ de probabil $\underline{i}$ dade.

\begin{tabular}{|c|c|c|c|}
\hline Variedade & $\begin{array}{c}\text { No de } \\
\text { repetições }\end{array}$ & $\begin{array}{l}\text { I.I. (dados } \\
\text { transformados) }\end{array}$ & $\begin{array}{l}\text { Classificasto } \\
\text { em relaçio ato } \\
\text { IC } 5 \%\end{array}$ \\
\hline IAC 52/150 & 14 & $17,86 a$ & Acima dal mêdial \\
\hline NA56-79 & 14 & $16,54 \mathrm{ab}$ & Acima da médial \\
\hline CP51-22 & 4 & $16,35 \mathrm{ab}$ & Ncima da médial \\
\hline $\mathrm{CB} 40-13$ & 12 & $16 ; 26 \mathrm{ab}$ & Neimal dal médial \\
\hline IAC $51 / 205$ & 8 & $15,81 \mathrm{ab}$ & Acima da média \\
\hline CB41- 76 & 14 & $15,80 \mathrm{ab}$ & Acima da média \\
\hline CB $41-14$ & 8 & $14,98 \mathrm{ab}$ & Dentro da média \\
\hline CB56-126 & 7 & $14,92 \mathrm{ab}$ & Dentro da média \\
\hline IAC52/.326 & 6 & $14,88 a b$ & Dentro da mëdia \\
\hline CB $46-47$ & 9 & $14,39 a b$ & Dentro da média \\
\hline CB49-260 & 8 & $\underset{0}{14,10} \mathrm{ab}$ & Dentro da média \\
\hline CB 36-24 & 4 & $13,05 \mathrm{ab}$ & Abaixo da média \\
\hline IAC 52/179 & 6 & $12,77 \mathrm{ab}$ & Abaixo da médi: \\
\hline CB $47-355$ & 11 & $12,65 \cdot a b$ & Mbaixo da médi: \\
\hline CB 49-62 & 7 & $12,20 a b$ & Nbaixo da média \\
\hline IAC50/134 & 6 & $11,46 \quad b$ & Abaixo da média \\
\hline Co 740 & 8 . & $10,93 \quad b$ & Abaixo da mécli: \\
\hline IAC $48 / 65$ & 7 & $10,82 . b$ & Mbaixo dal média \\
\hline
\end{tabular}


Tabela 18. Médias de Intensidade de Infestação (I.I.) por D. saccharalis em variedades de cana, amostri das em 1980, comparadas pelo teste de Tukey e pelo Intervalo de Confiança da média a $5 \%$.

\begin{tabular}{|c|c|c|c|}
\hline Variedade & $\begin{array}{l}\text { No de } \\
\text { repetições }\end{array}$ & $\begin{array}{l}\text { I.I. (dados } \\
\text { transformados) }\end{array}$ & $\begin{array}{c}\text { Classificació } \\
\text { em relaça a a } \\
\text { IC } 5 \%\end{array}$ \\
\hline IAC58/480 & 16 & $19,95 \mathrm{a}$ & Acima da média \\
\hline CP $51-22$ & 14 & $19,61 \mathrm{ab}$ & Acima da mêdia \\
\hline IAC 52-179 & 5 & $18,50 \mathrm{ab}$ & Acima da média \\
\hline $\operatorname{IAC} 51 / 205$ & 20 & 18,04 ab & Acima da média \\
\hline IAC $52 / 150$ & 25 & $18,01 \mathrm{ab}$ & Acima da mêdia \\
\hline NA56 - 79 & 27 & $17,74 \mathrm{ab}$ & 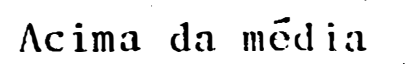 \\
\hline IAC $52 / 326$ & 6 & $16,78 \mathrm{ab}$ & Dentro da média \\
\hline CB 4 7-89 & 8 & $16,76 a b$ & Dentro da mêdia \\
\hline CB 56-86 & 4 & $16,73 a b$ & Dentro da média \\
\hline CB $40-13$ & 14 & $16,69 \mathrm{ab}$ & Dentro da média \\
\hline CB $36-24$ & 4 & $16,60 \mathrm{ab}$ & Dentro da média \\
\hline CB $41-14$ & 12 & $16,51 \mathrm{ab}$ & Dentro da média \\
\hline CB 53-98 & 17 & $16,27 \mathrm{ab}$ & Dentro da média \\
\hline CB41-76 & 25 & $16,06 \mathrm{ab}$ & Abaixo da méclia \\
\hline CB $49-260$ & 11 & $15,85 \mathrm{ab}$ & Abaixo da média \\
\hline IAC48/65 & 15 & 15,74 ab & Abaixo da média \\
\hline CB56-126 & 14. & $15,50 \mathrm{ab}$ & Abaixo da média \\
\hline Co 740 & 9 & $15,45 \mathrm{ab}$ & Abaixo da mêdia \\
\hline CB 4 7-355 & 23 & $15,09 a b$ & Lbaixo da média \\
\hline IAC $50 / 134$ & 4 & $14,80 \mathrm{ab}$ & Abaixo da média \\
\hline CB $46-47$ & 9 & $14,54 a b$ & Abaixo dal média \\
\hline CB 49-62 & 9 & $14,13 a b$ & 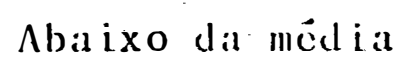 \\
\hline CB56-155 & 4 & $13,64 \mathrm{ab}$ & Abaixo dal média \\
\hline Co775 & 5 & $11,29 \quad b$ & Abaixo da média \\
\hline
\end{tabular}


Tabela 19. Médias de Intensidade de Infestação (I.I.) por D. saccharalis em variedades de cana, amostralals em 1981, comparadas pelo teste de Tukey e pelo Intervalo de Confiança da média a $5 \%$

\begin{tabular}{|c|c|c|c|}
\hline Variedade & $\begin{array}{l}\text { No de } \\
\text { repetições }\end{array}$ & $\begin{array}{l}\text { I.I. (dados } \\
\text { transformados) }\end{array}$ & $\begin{array}{l}\text { Classificiasiono } \\
\text { em relação ao } \\
\text { IC 5: }\end{array}$ \\
\hline CP $51-22$ & 17 & 18,31 a & Acima da média \\
\hline SP70-1005 & 8 & $17,86 \mathrm{ab}$ & Acima da médial \\
\hline IAC $58 / 480$. & 17 & $17,04 \mathrm{ab}$ & Acima da médial \\
\hline CB 41-14 & 15 & $16,63 \mathrm{ab}$ & Acima da média \\
\hline CB40-13 & 12 & $16,17 \mathrm{ab}$ & Acima da média \\
\hline NA56-79 & 25 & $15,98 \mathrm{ab}$ & Acima da média \\
\hline SP70-3370 & 5 & $15,91 \mathrm{ab}$ & Acima da media \\
\hline SP 7.0- 1078 & 7 & $15,85 \mathrm{ab}$ & Acima da média \\
\hline $\operatorname{IAC} 52 / 150$ & 25 & $15,69 \mathrm{ab}$ & Acima da média \\
\hline SP 70-1143 & 10 & $15,64 \mathrm{ab}$ & Acima da média \\
\hline IAC $51 / 205$ & 18 & $15,46 a b$ & Acima da mëdia \\
\hline $\mathrm{CB} 45-155$ & 5 & $14,59 \mathrm{ab}$ & Dentro da média \\
\hline CB $46-47$ & 8 & $14,50 \mathrm{ab}$ & Dentro da média \\
\hline IAC $52 / 326$ & 4 & $14,40 \mathrm{ab}$ & Abaixo da média \\
\hline $\operatorname{IAC} 52 / 179$ & 5 & $14,10, a b$ & Abaixo da mëclia \\
\hline CB $41-76$ & 19 & $14,05 \mathrm{ab}$ & Abaixo da média \\
\hline CB $49-62$ & 8 & $13,90 \mathrm{ab}$ & Abaixo da mēdial \\
\hline Co775 & 5 & $13,86 \mathrm{ab}$ & Abaixo da média \\
\hline CB 56-86 & 4 & $13,70 \mathrm{ab}$ & Abaixo da mêdia \\
\hline Co740 & 8 & $13,56 \mathrm{ab}$ & Abaixo da média \\
\hline CB $49-260$ & 7 & $13,44 \mathrm{ab}$ & Abaixo da média \\
\hline CB53-98 & 17 & $13,32 \mathrm{ab}$ & Abaixo da média \\
\hline CB $47-355$ & 23 & $13,16 \quad b$ & Abaixo da média \\
\hline СВ56-126 & 10 & $13,11 \mathrm{ab}$ & Abaixo da média \\
\hline IAC $48 / 65$ & 15 & $12,83 \mathrm{ab}$ & Abaixo da média \\
\hline CB 47-89 & 9 & $12,46 \mathrm{ab}$ & Abaixo da média \\
\hline SP 70-1284 & 6 & $11,29 \mathrm{ab}$ & Abaixo da média \\
\hline
\end{tabular}


Tabela 20. Infestação final causada pela broca em 4 varie dades de cana planta, amostrando 100 canas por variedade. CTLJ, 1979

\begin{tabular}{|c|c|c|c|c|}
\hline \multirow{2}{*}{$\begin{array}{l}\text { Variedade } \\
\text { de cana }\end{array}$} & \multirow{2}{*}{$\begin{array}{l}\text { \% canas } \\
\text { broqueadas }\end{array}$} & \multicolumn{2}{|c|}{ Tota1 entrenós } & \multirow{2}{*}{$\begin{array}{l}\text { : entrenus } \\
\text { brocucialos }\end{array}$} \\
\hline & & Examinados & Broqueados & \\
\hline CB $40-13$ & 96,0 & 2.115 & 534 & 25,25 \\
\hline $\operatorname{IAC5} 2 / 150$ & 83,0 & 1.649 & 338 & 20,50 \\
\hline CB $47-355$ & 86,0 & 1.730 & 341 & 19,71 \\
\hline SP70-1499 & 79,0 & 1.591 & 241 & 15,15 \\
\hline
\end{tabular}

Qui-quadrado $=57,8366^{* *}$

A comparação estatística destas 4 varicdades, mostra que houve maior porcentagem de entrenós broqucialos na variedade CB40-13 e menor nas variedades SP70-1499 c CB47-355.

\subsubsection{Levantamentos popuiaciona is}

Os resultados desses levantamentos $\mathrm{cm}$ [uncĩo das variedades mais amostradas em 3 Usinas do Estado de São Paulo, em 1981, estão apresentados nas Tabelas 21,22 c 23. 
Tabela 21. Densidade populacional relativa (coleta por ho ra/homem) e parasitismo da broca en seis virieda des de cana na Usina Barra Grande, SP, em 1981

\begin{tabular}{lccccc}
\hline \multirow{2}{*}{$\begin{array}{l}\text { Variedade } \\
\text { de cana }\end{array}$} & $\begin{array}{l}\text { Densidade } \\
\text { populac. }\end{array}$ & \multicolumn{4}{c}{ O Parasitismo } \\
\cline { 4 - 6 } & relativa & $\begin{array}{l}\text { M. mi } \\
\text { nense }\end{array}$ & $\begin{array}{c}\text { P. clari } \\
\text { palpis }\end{array}$ & $\begin{array}{c}\text { Braco } \\
\text { nidcos }\end{array}$ & Total \\
\hline NA56-79 & 18,3 & 25,4 & 10,0 & 0,3 & 35,7 \\
IAC51/205 & 20,8 & 13,9 & 12,6 & 0,4 & 26,9 \\
CB45-155 & 16,9 & 14,6 & 13,7 & 0,2 & 28,5 \\
IAC52/150 & 25,0 & 16,8 & 10,2 & 0,2 & 27,2 \\
SP70-1143 & 6,9 & 15,4 & 6,1 & 0,4 & 21,9 \\
IAC48/65 & 5,0 & 11,5 & 30,3 & 1,0 & 12,8 \\
\hline
\end{tabular}

Tabela 22. Densidade populacional relativa (coleta por ho $\mathrm{ra} /$ homem) e parasitismo da broca cm tres varicda des de cana, na Usina Santa Luiza, SP, em 1981

\begin{tabular}{|c|c|c|c|c|c|}
\hline \multirow{2}{*}{$\begin{array}{l}\text { Variedade } \\
\text { de cana }\end{array}$} & \multirow{2}{*}{$\begin{array}{l}\text { Densidade } \\
\text { populac. } \\
\text { relativa }\end{array}$} & \multicolumn{4}{|c|}{ : Parasitismo } \\
\hline & & $\begin{array}{l}\text { M. mi } \\
\text { nense }\end{array}$ & $\begin{array}{l}\text { P. clari } \\
\text { palpis }\end{array}$ & $\begin{array}{l}\text { Braco } \\
\text { nídeos }\end{array}$ & lotal \\
\hline NA56- 79 & 13,8 & 18,2 & 19,3 & 0,1 & 37,6 \\
\hline IAC52 / 150 & 11,7 & 11,8 & 19,1 & 0,1 & 31,0 \\
\hline СВ41-14 & 9,1 & 26,7 & 11,0 & 0,0 & $.37,7$ \\
\hline
\end{tabular}


Tabela 23. Densidade populacional relativa (colcta por ho ra/homem) e parasitismo da broca em nove variedi des de cana, na Usina Santa Cruz S. $\Lambda_{0}, S P, \quad \mathrm{~cm}$ 1981

\begin{tabular}{|c|c|c|c|c|c|}
\hline \multirow{2}{*}{$\begin{array}{l}\text { Variedade } \\
\text { de cana }\end{array}$} & \multirow{2}{*}{$\begin{array}{l}\text { Densidade } \\
\text { populac. } \\
\text { relativa }\end{array}$} & \multicolumn{4}{|c|}{ : Parasitismo } \\
\hline & & $\begin{array}{l}\text { M. mi } \\
\text { nense }\end{array}$ & $\begin{array}{l}\text { P. clari } \\
\text { palpis }\end{array}$ & $\underset{\text { nídeos }}{\text { Braco }}$ & Tot a 1 \\
\hline NA56-79 & 17,6 & 43,1 & 0,1 & 3,4 & 40,0 \\
\hline SP 70-1143 & 14,2 & 28,2 & 1,0 & 5,8 & 35,0 \\
\hline SP71-799 & 9,6 & 40,2 & 1,1 & 3,6 & 44,9 \\
\hline IAC $52 / 150$ & 11,4 & 40,0 & 0,3 & 7,3 & 47,6 \\
\hline SP71-1406 & 9,2 & 43,3 & 0,5 & 1,1 & 44,9 \\
\hline SP70-1078 & 5,6 & 27,1 & 0,6 & 7,2 & 34,9 \\
\hline SP 71-3501 & 19,8 & 28,0 & 0,1 & 4,6 & 32,7 \\
\hline CP51-22 & 19,1 & 46,1 & 0,9 & 2,1 & 49,1 \\
\hline CB $47-355$ & 10,7 & 28,0 & 0,7 & 4,1 & 32,8 \\
\hline
\end{tabular}

Esses dados apresentaram diferenças, tanto na densidade populacional da broca como no seu parasitismo, para as diversas variedades amostradas. Porém, o comporta mento das variedades foi diferente en cada local de estudo. Portanto, as diferenças não são consistentes nem compira veis, possivelmente devido a outras variáveis que interte riram nesse comportamento, tais como idade do canavial e da cana.

Os levantamentos populacionais nas 4 varie dades de cana, comparadas na CTEJ, mostraram os resultalos da Tabe1a 24 . 
Tabela 24. Densidade populacional relativa (coleta por ho ra/homem) e parasitismo da broca em 4 variedales de cana de primeiro corte, e da mesma idade de crescimento. CTEJ, jan。-fev。/79。

\begin{tabular}{|c|c|c|c|c|c|}
\hline \multirow{2}{*}{$\begin{array}{l}\text { Variedade } \\
\text { de cans }\end{array}$} & \multirow{2}{*}{$\begin{array}{l}\text { Densidade } \\
\text { populacional } \\
\text { relativa }\end{array}$} & \multicolumn{4}{|c|}{ : Parasitismo } \\
\hline & & $\begin{array}{l}M \cdot m i \\
\text { nense }\end{array}$ & $\begin{array}{l}\text { P. clari } \\
\text { palpis }\end{array}$ & $\begin{array}{l}\text { Bracos } \\
\text { nídeos }\end{array}$ & Total \\
\hline $\mathrm{CB} 40-13$ & 4,2 & 30,3 & 1,6 & 0,0 & 31,9 \\
\hline IAC $52 / 150$ & 5,7 & 43,4 & 1,1 & 0,0 & 44,5 \\
\hline CB $47-3.55$ & 3,1 & 37,1 & 1,6 & 1,6 & 40,3 \\
\hline SP70-1499. & 5,2 & 31,4 & 0,9 & 0,0 & 32,3 \\
\hline
\end{tabular}

Qui-quadrado $=8,7598 *$

Neste caso, a densidade populacional foi maior na variedade IAC52/150 e menor em CB47-355. Por outro laclo, o parasitismo da broca foi maior na variedade I AC52/150 e menor em CB40-13.

4.3.3. Testes de controle natural de ovos da broca

Na Tabela 25 estão resumidos os resultados de nove testes efetuados nas quatro variedades de cana compara das na CTEJ.

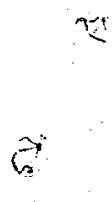


Tabe1a 25. Controle natural (induzido) de ovos de 0 . saccharalis em 4 variedades de cana de primeiro corte. CTEJ, set./78 a jun./79.

\begin{tabular}{|c|c|c|c|c|c|}
\hline \multirow{2}{*}{$\begin{array}{l}\text { Variedade } \\
\text { de cana }\end{array}$} & \multirow{2}{*}{$\begin{array}{l}\text { ovos } \\
\text { expostos }\end{array}$} & \multicolumn{3}{|c|}{ : de ovos } & \multirow{2}{*}{$\begin{array}{c}\text { Controle } \\
\text { natural } \\
?\end{array}$} \\
\hline & & parasitados & mastigados & sugados & \\
\hline CB $40-13$ & 809 & 1,1 & 22,9 & 42,4 & 00,38 \\
\hline IAC 52/ 150 & 768 & 11,6 & 9,8 & 36,3 & 57,68 \\
\hline CB $47-355$ & 791 & 7,0 & 16,8 & 38,0 & 01,82 \\
\hline SP70-1499 & 806 & 3,3 & 21,3 & 31,9 & 50,58 \\
\hline
\end{tabular}

Qui-quadrado $=20,0171 * *$

A anålise estatística revelou um mior contro le nas variedades $C B 40-13$ e $C B 47-355$, enquanto que foi me nor nas variedades SP70-1499 e IAC52/150.

\subsubsection{Testes de sobrevivência e duração do ciclo biológico}

A Tabela 26 apresenta os resultados de 0 tes tes desenvolvidos na CTES, em condições de teladọ.

Tabela 26. Sobrevivência e duração do periodo larva + pupa de 0 . saccharalis, em 2 variedades de cana. Teli do da CTES, $21 / 11 / 78$ a $11 / 10 / 79$.

\begin{tabular}{|c|c|c|c|c|c|}
\hline \multirow{2}{*}{$\begin{array}{l}\text { Variedade } \\
\text { de cana }\end{array}$} & \multirow{2}{*}{$\begin{array}{l}\text { larvas } \\
\text { "inoculadas" }\end{array}$} & \multicolumn{2}{|c|}{ o sobrevivência de } & \multirow{2}{*}{\multicolumn{2}{|c|}{$\begin{array}{l}\text { Luração mêdial } \\
\text { larval + mullal }\end{array}$}} \\
\hline & & pupas & adul tos & & \\
\hline NA56- 79 & 1.248 & 13,9 . & 13,9 & 59,8 & dials \\
\hline IAC $48 / 65$ & 1.221 & 11,5 & 11,4 & 62,5 & dias \\
\hline
\end{tabular}

Qui-quadrado $=3,6485 \mathrm{n} . \mathrm{s}$. 
Năo foi detectada diferença estatística nas sobrevivências atê o estado adulto. Por outro lado, a di le rença na duração do período larva + pupa foi pequeni.

Na Tabela 27 estão os resultados de 2 testes efetuados na Usina Barra Grande, em condições de campo aber to.

Tabela 27. Sobrevivência e duração do período larva + pupa de $D$. saccharalis, em 2 variedades de cana. Usina Barra Grande, SP。out./77 a jun./78.

\begin{tabular}{lcccc}
\hline Variedade & larvas & o sobrevivência de & nurasió mília \\
\cline { 3 - 5 } de cana & inoculadas & pupas & adultos & 1 arva + pupa \\
\hline NA56-79 & 160 & 6,9 & 3,7 & 50,3 dias \\
CB41-76 & 200 & 4,0 & 2,5 & 57,2 dias \\
\hline
\end{tabular}

Qui-quadrado $=0,4688 \mathrm{n} . \mathrm{s}$.

Não foi detectada diferença estatística çuando comparadas as sobrevivências. Porém, houve encurtamento do período larva + pupa na variedade NA56-79, repetindo a tendência registrada nos testes anteriores (Tabela 26).

Os resultados de 8 testes realizados nas 1 vä riedades comparadas na CTEJ, estão resumidos na Tabcla 28 . 
Tabela 28. Sobrevivência de 875 ovos "cabeça preta", e dura ção do período larva + pupa de 0 . saccharalis, $\mathrm{cm}$ 4 variedades de cana. CTEJ, set./78 a mar./79

\begin{tabular}{lccc}
\hline Variedade & \multicolumn{2}{c}{ \& Sobrevivência de } & Duração média \\
\cline { 2 - 3 } de cana & pupas & adu1tos & larva + pupa \\
\hline CB40-13 & 2,7 & 2,3 & 51,5 dias \\
IAC52/150 & 1,8 & 1,4 & 55,3 dias \\
CB47-355 & 3,7 & 2,3 & 53,8 diats \\
SP70-1499 & 2,3 & 1,4 & 51,6 dials \\
\hline
\end{tabular}

Qui-quadrado $=3,7862$ n.s.

A anălise dos dados de sobrevivência de adu 1 tos não deu significância estatística, nem mostrou diferen ças apreciáveis na duração do período larva + pupa.

4.3.5. Testes sobre capacidade reprodutiva de $D$. saccharalis

Os testes desenvolvidos na CTEJ, utilizanclo adul tos criados em 4 variedades, resultaram nos dados da Tabela 29.

Tabela 29. Resultados de 6 testes sobre capacidade reprodu tiva de $D$. saccharalis, criadas em 4 variedales de cana de primeiro corte. CTEJ, jan.-mar./79

\begin{tabular}{lcccc}
\hline $\begin{array}{l}\text { Variedade } \\
\text { de cana }\end{array}$ & No de & ovos obtidos por $\$$ & Viabilidade \\
\cline { 3 - 5 } & casais & Tota 1 & Viriveis & $\%$ \\
\hline CB40-13 & 10 & 340,5 & 294,5 & 86,49 \\
IAC52/150 & 11 & 418,6 & 415,2 & 98,15 \\
CB47-355 & 6 & 299,5 & 268,3 & 89,59 \\
SP70-1499 & 6 & 354,0 & 302,3 & 85,40 \\
\hline
\end{tabular}

Qui-quadrado $=53,5809^{* *}$ 
A anålise estatística mostrou maior nümero dc ovos viäveis na variedade IAC52/150 e menor nas outras vâ riedades.

\subsection{Estado nutricional da cana}

Os estudos feitos em experimentos e testes comparando diversas adubações na cana, deram os resultidos seguintes.

\subsubsection{Levantamentos de infestação fina 1}

Os levantamentos realizados durante a colhei ta de experimentos com níveis crescentes dos 3 macronutrien tes nas Usinas São Geraldo e Santa Luiza, resultaram nos diı dos da Tabela 30 .

Observou-se que todos os tratamentos adubiclos sofreram maior infestação que a testemunha absoluta. Nos tratamentos adubados, os valores de I.I. ( $\%$ de entrenós bro queados) mostraram tendências definidas. Assim, registrou-se tendência de aumento de infestạção com doses crescentes de $\mathrm{N}$ e $\mathrm{K}_{2} \mathrm{O}$, exceto na ültima dose de $\mathrm{N}$. Por outro laclo, existiu tendência a diminuir essa infestação com as doses crescentes de $\mathrm{P}_{2} \mathrm{O}_{5}$ (Figura 11). 
Tabela 30. Infestação final da cana pela broca em exper mentos de adubação nas Usinas São cieraldo e San ta Luiza, SP. Médias de 60 canas cxaminadas, variedade NA56-79 de 29 corte.

\begin{tabular}{|c|c|c|c|c|c|}
\hline \multicolumn{3}{|c|}{$\begin{array}{l}\text { Tratamento } \\
\text { (adubação da cana) }\end{array}$} & \multicolumn{2}{|c|}{ Tota1 entrenós } & \multirow{2}{*}{$\begin{array}{l}\text { I.I. }\left(\begin{array}{l}a \\
0\end{array} \text { de }\right. \\
\text { entrenús } \\
\text { broqueados })\end{array}$} \\
\hline $\mathrm{N}$ & - P &.$- K$ & Examinados & Broqueados & \\
\hline 0 & - & - & 1.217 & 163 & 13,39 \\
\hline 0 & -120 & -180 & 1.201 & 200 & 16,65 \\
\hline 30 & -.120 & -180 & 1.068 & 200 & 18,73 \\
\hline 60 & -120 & -180 & 1.181 & 234 & 19,81 \\
\hline 9.0 & -120 & -180 & 1.180 & 244 & 20,68 \\
\hline 120 & -120 & -180 & 1.180 & 208 & 17,63 \\
\hline 60 & -0 & -180 & 1.231 & 239 & 19,41 \\
\hline 60 & -60 & -180 & 1.191 & 221 & 18,55 \\
\hline 60 & -180 & -180 & 1.197 & 215 & 17,96 \\
\hline 60 & -240 & -180 & 1.223 & 189 & 15,45 \\
\hline 60 & -120 & $-\quad 0$ & 1.203 & 190 & 15,79 \\
\hline 60 & -120 & -60 & 1.200 & 190 & 15,83 \\
\hline 60 & -120 & -120 & 1.247 & 240 & 19,25 \\
\hline 60 & -120 & -240 & 1.194 & 270 & 22,61 \\
\hline 90 & -180 & -180 & 1.224 & 253 & 20,67 \\
\hline
\end{tabular}




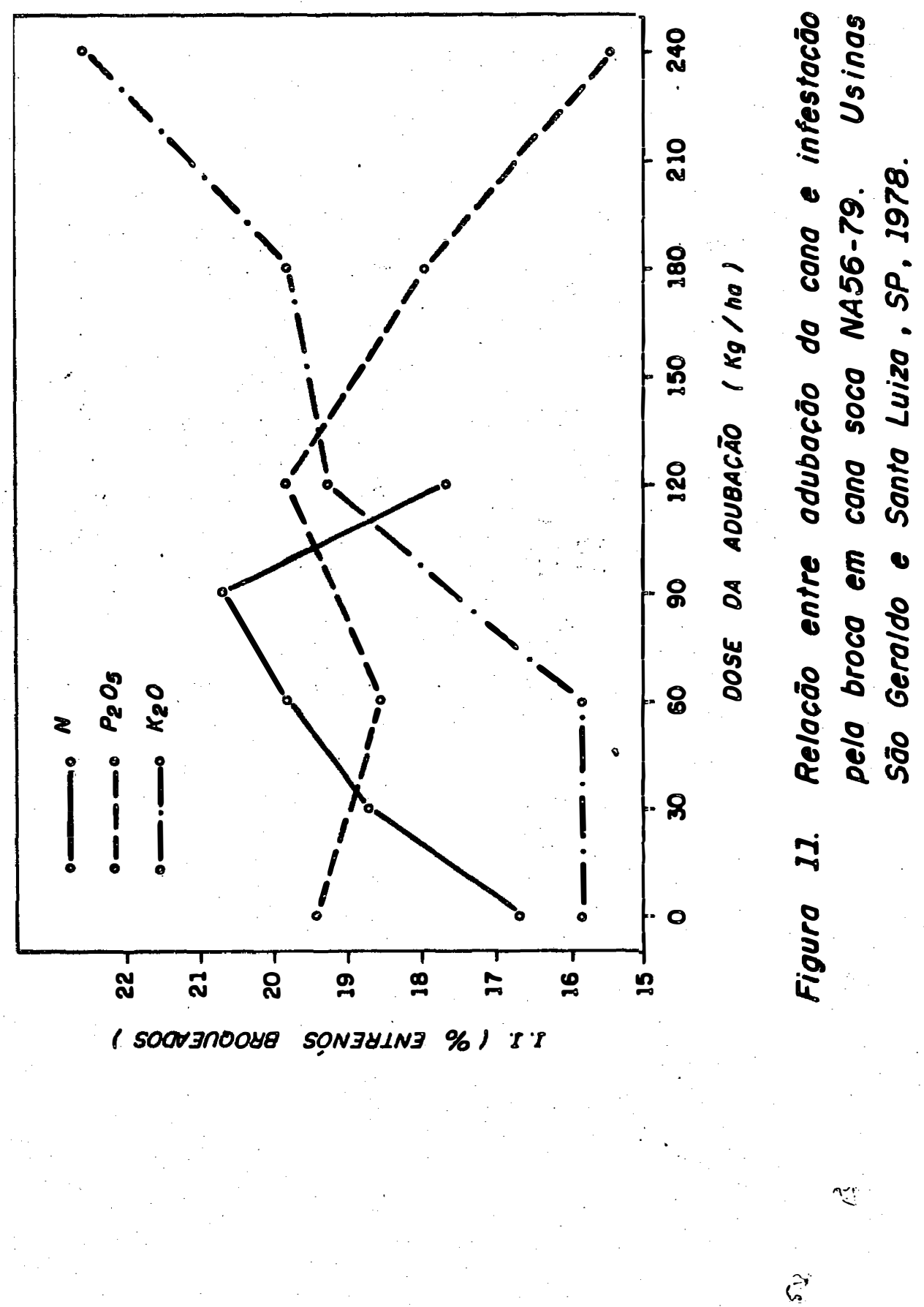


Esses valores submetidos à anälise de regres são, mostraram significância para as doses crescentes de $\mathrm{K}_{2} \mathrm{O}$ ao nível de $1 \%$ de probabilidade $\left(\mathrm{r}=0,9024^{* *}\right)$ c para as de $\mathrm{P}_{2} \mathrm{O}_{5}$ ao nîvel de 5\% $\left(\mathrm{r}=-0,7837^{*}\right)$. A correlação para as doses de $K_{2} O$ esteve representada pela equacia $Y=15,1.318+$ $+0,0294 \mathrm{X}$ e para as doses de $\mathrm{P}_{2} \mathrm{O}_{5}$ pela equaç̃o $Y=19,9376-0,0142 X$ 。

A Tabela 31 registra a infestaço fina 1 de parcelas adubadas diferencialmente na Fazenda Santo Antonio da Usina São Josẽ ZL.

Tabe1a 31. Infestação final pela broca, em cana I $1552-150$ de 1 o corte adubada diferencialmente, cm amos tras de 100 canas por tratamento. Usina São José $\mathrm{ZL}, \mathrm{SP}, 1978$.

\begin{tabular}{lcccc}
\hline $\begin{array}{l}\text { Adubação } \\
\text { da cana }\end{array}$ & $\begin{array}{c}: \text { canas } \\
\text { broqueadas }\end{array}$ & Examinados & Broqueados & $\begin{array}{c}\text { Total de entrenós } \\
\text { broqucaclos }\end{array}$ \\
\hline Nitrogenada & 94,0 & 2.019 & 398 & 19,71 \\
Potåssica & 90,0 & 1.990 & 366 & 18,39 \\
Testemunha & 89,0 & 2.031 & 357 & 17,57 \\
\hline
\end{tabular}

Qui-quadrado $=3,1090 \mathrm{n} . \mathrm{s}$ 。

A infestação final registrada en parcelas adu badas diferencialmente na Fazenda Patos da Usina São Jos $Z L$, estā aprescntada na Tabcla 32 . 
Tabela 32. Infestação final pela broca, em cana

plintil NA56-79 adubada diferencialmente, em amostras de 200 canas por tritamento. Usina São Jose $Z$ I., Sl, 1979 。

\begin{tabular}{|c|c|c|c|c|}
\hline \multirow{2}{*}{$\begin{array}{l}\text { Adubação } \\
\text { de cana }\end{array}$} & \multirow{2}{*}{$\begin{array}{c}\text { :Canas } \\
\text { broqueadas }\end{array}$} & \multicolumn{2}{|c|}{ Total entrenós } & \multirow{2}{*}{$\begin{array}{l}\text { : Entrenós } \\
\text { broqueados }\end{array}$} \\
\hline & & Examinados & Brocqueados & \\
\hline Fós foro & 75,0 & 3.880 & 411 & $10,5 !$ \\
\hline Potássio & 76,5 & 4.081 & 427 & 10,46 \\
\hline Nitrogênio & 79,0 & 3.944 & 404 & 10,24 \\
\hline Silício & 74,5 & 4.011 & 404 & 10,07 \\
\hline Cālcio & 71,5 & 4.095 & 386 & $9,4 \pi$ \\
\hline Testemunha & 69,0 & 3.907 & 342 & 8,75 \\
\hline Zinco & 65,0 & 4.097 & 348 & 8,49 \\
\hline
\end{tabular}

Qui-quadrado $=19,3203 * *$

Os dados submetidos à anålise estatísticia mos traram maior infestação nos tratamentos com fósforo, potás sio, nitrogênio e silício em comparação com os tratimentos zinco, cálcio e testemunha.

4.4.2. Levantamentos populacionais

Os resultados desses levantamentos efetuados nas parcelas adubadas diferencialmente na Fazenda Patos da Usina São Josê $Z L$, estão resumidos na Tabcla 33 . 
Tabela 33. Densidade populacional (coleta por ha) e parasi tismo da broca em cana NA56-79 plantada com allu bações diferenciadas na Usina São Josê ZL, SP. Mëdias pondcradas de 3 colctas.

\begin{tabular}{|c|c|c|c|c|}
\hline \multirow{2}{*}{$\begin{array}{l}\text { Adubação } \\
\text { da cana }\end{array}$} & \multirow{2}{*}{$\begin{array}{l}\text { Densidade } \\
\text { populacional } \\
\text { por ha }\end{array}$} & \multicolumn{3}{|c|}{ : Parasitismo } \\
\hline & & $\begin{array}{l}\text { M. mi } \\
\text { nense }\end{array}$ & $\begin{array}{l}\text { P. clari } \\
\text { palpis }\end{array}$ & Total \\
\hline Nitrogênio & 4.311 & 47,3 & 2,7 & 50,0 \\
\hline Potåssio & 3.068 & 46,9 & 4,9 & 51,8 \\
\hline Fösforo & 3.014 & 54,1 & 2,0 & 56,1 \\
\hline Silício & 2.508 & 52,5 & 4,4 & 56,9 \\
\hline Zinco & 1.651 & 51,9 & 3,8 & 55,7 \\
\hline Cá1cio & 1.312 & 45,2 & 3,6 & 48,8 \\
\hline Testemunha & 1.253 & 43,0 & 4,4 & 47,4 \\
\hline
\end{tabular}

Os valores de densidade populacional guarda ram relação com os valores de infestação final (4.4.1); is to è houve maior densidade populacional nos tratamentos com fôsforo, potāssio, nitrogênio è silício.

Esses dados, separados para as 3 datas de co letas, estão comparados nas Tabelas 34 e 35 .

A anảlise de variância não demonstrou diferen ças significativas entrc tratamentos, tanto para os valores de densidade populacional ('Tabela 34), como para os valores de parasitismo da broca por taquinídeos (labela 35). Huuve di ferenças apenas para os valores de densidade populacional em função da época da amostragem, pelo teste lukey ao nível de $5 \%$ de probabilidade. 
Tabe1a 34. Densidade populacional da broca por ha, em canil planta NA56-79, sujeita a adubaçöes diferencial das. Levantamentos efetuados em 3 etapas de crescimento da cana, na Fazenda patos da llsina São Josẽ ZL, SP

\begin{tabular}{|c|c|c|c|c|}
\hline \multirow{2}{*}{$\begin{array}{l}\text { Tratamentos } \\
\text { (adubação } \\
\text { da cana) }\end{array}$} & \multicolumn{3}{|c|}{ Blocos (I dade da cana) } & \multirow{2}{*}{ Medial } \\
\hline & $\begin{array}{c}I \\
(7 \text { meses })\end{array}$ & $\begin{array}{c}\text { I I } \\
(8 \text { moses })\end{array}$ & $\begin{array}{c}\text { I I I } \\
(9 \text { meses })\end{array}$ & \\
\hline Nitrogênio & $\cdot 2.692$ & 7.576 & 2.500 & 1.250 \\
\hline Potâssio & 1.375 & 6.667 & 1.292 & .3 .111 \\
\hline Fös foro & 1.348 & 6.174 & 1.391 & 2.971 \\
\hline Silicio & 1.142 & 4.714 & 1.666 & 2.507 \\
\hline Zinco & 1.142 & 2.571 & 1.238 & 1.650 \\
\hline Cālcio & 1.048 & 810 & 2.142 & 1.333 \\
\hline Testemunha & 1.833 & 1.000 & 967 & 1.267 \\
\hline Total & 10.580 & 29.512 & 11.196 & \\
\hline Mêdia & $1.511 \mathrm{a}$ & $4.216 b$ & $1.599 a$ & \\
\hline
\end{tabular}

$\begin{aligned} \mathrm{F}(\text { Tratamentos }) & =1,6277 \mathrm{n} . \mathrm{s} . \\ \mathrm{F}(\mathrm{B} 1 \mathrm{ocos}) & =6,0973^{*}\end{aligned}$


Tabela 35. Parasitismo ( $\left(\begin{array}{l}0 \\ 0\end{array}\right)$ da broca por moscas taquinidcas (M. minense + P. claripalpis) em cana planta NA56-79, sujeita a adubações diferenciadas. Le vantamentos efetuados em 3 etapas de crescimen to da cana. Fazenda Patos da Usina São Jose $z$ L, SP.

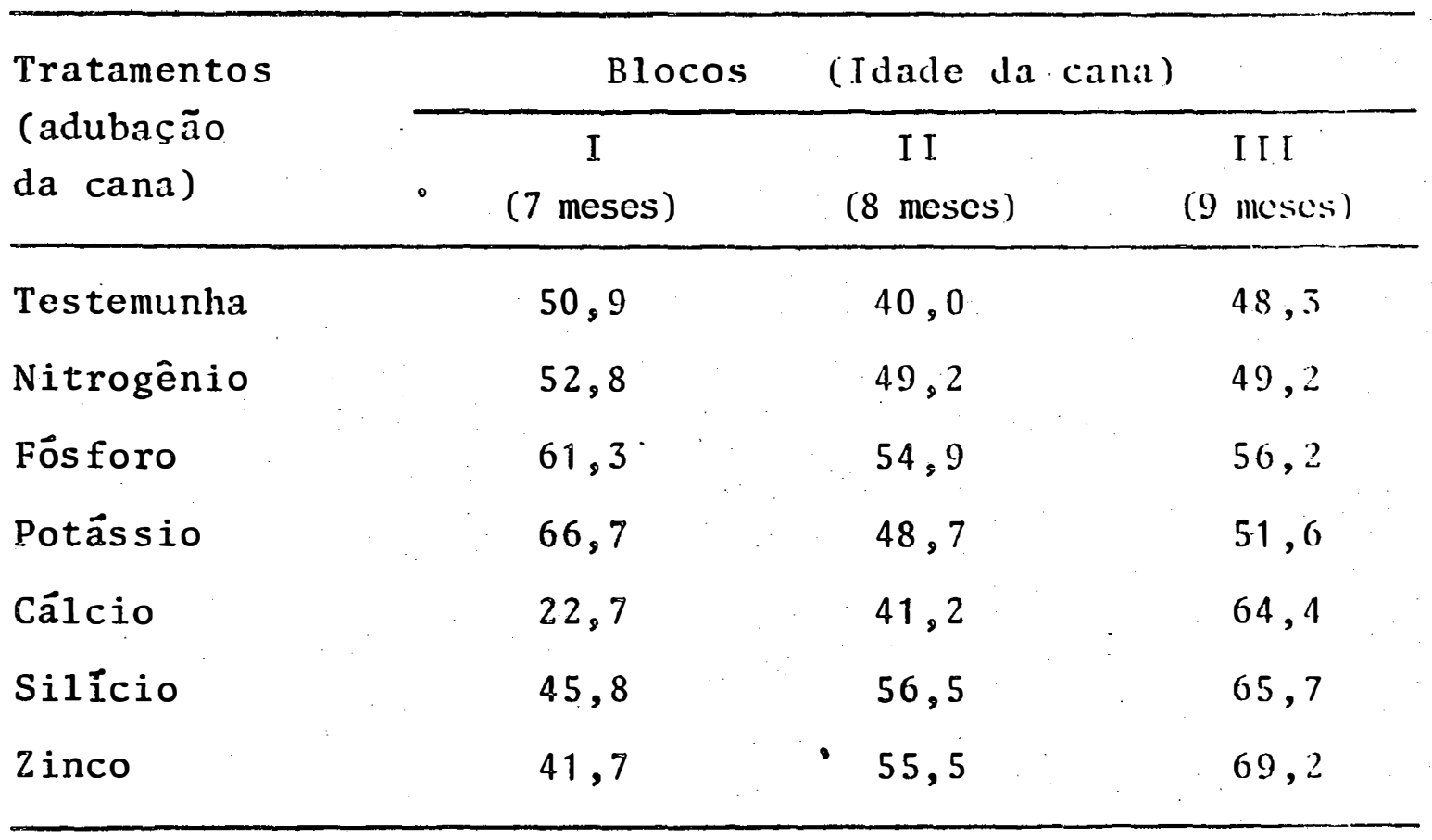

$\mathrm{F}($ Tratamentos $)=0,8308 \mathrm{n} \cdot \mathrm{s}$ 。

$F($ blocos $) \quad=1,5210 \mathrm{n} . \mathrm{s}$. 
4.4.3. Testes de controle natural de ovos da brocia

Os resultados daqueles estudos mencionados cm 3.4.3, todos efetuados cm canaviais da Usina Sĩo Jose El, estão apresentados nas Tabclas 36,37 e 38 .

Tabela 36. Controle natural (induzido) de ovos de D. saccha ralis em 2 canaviais plantados, em solos de di ferentes fertilidades com a variedade $N \Lambda 5(1-7 !$. Usina São José ZL, SP. Março de 1978 .

\begin{tabular}{|c|c|c|c|c|c|}
\hline \multirow{2}{*}{$\begin{array}{l}\text { Fertilidade } \\
\text { do solo }\end{array}$} & \multirow{2}{*}{$\begin{array}{c}\text { ovos } \\
\text { expostos }\end{array}$} & \multicolumn{3}{|c|}{ \% de ovos } & \multirow{2}{*}{$\begin{array}{c}\text { Controle } \\
\text { natural } \\
:\end{array}$} \\
\hline & & parasitados & mastigados & sugaclos & \\
\hline $\begin{array}{l}\text { Baixa (Faz. } \\
\text { Sede 14-08) }\end{array}$ & 326 & 6,4 & 78,2 & 13,2 & 97,85 \\
\hline $\begin{array}{l}\text { Alta (Faz. Pouso } \\
\text { Alegre 06-05) }\end{array}$ & 322 & 0,0 & 59,0 & 25,5 & 84,47 \\
\hline
\end{tabular}

Qui-quadrado $=36,1530 * *$

Tabela 37. Controle natural (induzido) de ovos de D. saccharal is, em cana planta IAC52/150 adubada diferencialmentc, na Fazenda Sto. Antonio da Usina S. Jos ć ZI, SP.

\begin{tabular}{|c|c|c|c|c|c|}
\hline \multirow{2}{*}{$\begin{array}{l}\text { Adubação } \\
\text { da cana }\end{array}$} & \multirow{2}{*}{$\begin{array}{c}\text { ovos } \\
\text { expostos }\end{array}$} & \multicolumn{3}{|c|}{ o de ovos } & \multirow{2}{*}{$\begin{array}{c}\text { Controle } \\
\text { natural }\end{array}$} \\
\hline & & parasitados & mastigados & sugaclos & \\
\hline Nitrogenada & 149 & 28,2 & 63,8 & 8,0 & 100,0 \\
\hline Potảssica & 152 & 0,0 & 100,0 & 0,0 & 100,0 \\
\hline Testemunha & 149 & 3,4 & - 96,6 & 0,0 & 10()$, 0$ \\
\hline
\end{tabular}


Tabela 38. Controle natural (induzido) de ovos de $D$. saccharalis, em cana planta NA56-79 adubạda dife rencialmente, na Fazenda Patos da Usina São José ZL, SP.

\begin{tabular}{|c|c|c|c|c|c|}
\hline \multirow{2}{*}{$\begin{array}{l}\text { Adubação } \\
\text { da cana }\end{array}$} & \multirow{2}{*}{$\begin{array}{c}\text { ovos } \\
\text { expostos }\end{array}$} & \multicolumn{3}{|c|}{$\stackrel{\circ}{\mathrm{de}}$ ovos } & \multirow{2}{*}{$\begin{array}{c}\text { Controle } \\
\text { natural } \\
\end{array}$} \\
\hline & & parasitados & mastigalos & sugaiclos & \\
\hline Nitrogênio & 95 & 17,9 & 72,6 & 0,0 & $9(1,5.5$ \\
\hline Fös foro & 81 & 7,4 & 69,1 & 6,2 & 82,53 \\
\hline Potâssio & 99 & 21,2 & 52,5 & 14,1 & 87,88 \\
\hline Silício & 99 & 20,2 & 45,4 & 11,1 & 70,77 \\
\hline Cälcio & 86 & 9,3 & 52,3 & 17,4 & 79,07 \\
\hline Zinco & 98 & 34,7 & 29,6 & 7,1 & 71,43 \\
\hline Testemunha & .106 & 21,7 & 71,7 & 0,0 & $9.3,40$ \\
\hline
\end{tabular}

Qui-quadrado $=26,8945 * *$

No primeiro estudo (Tabela 36) o controle nal tural dos ovos foi maior na cana plantada em solo de haixa fertilidade. Para o segundo estudo. (Tabela 37) não foi pos sível detectar diferenças, porque a mortalidadc natural clos ovos foi total nos 3 tratamentos. No terceiro estudo ('libe 1a 38) houve maior controle na Testemunha e nos tratamentos com Nitrogênio e Potássio.

4.4.4. Testes de sobrevivência e duração do ciclo biológico

Os testes descritos em 3.4.4. rornecerall os resultados comparativos das Tabclas 39 a 42 . 
Tabela 39. Sobrevivência de 180 larvas recêm cclodidas, c duração do período larva + pupa de D. saccharctés, em cana I AC52/150, adubada diferencialmente: nal Fazenda Santo Antonio da Usina São Josã ZI, SlP. Nov.-Dez./77.

\begin{tabular}{|c|c|c|c|}
\hline \multirow{2}{*}{$\begin{array}{l}\text { Adubação } \\
\text { da cana }\end{array}$} & \multicolumn{2}{|c|}{ : Sobrevivência de } & \multirow{2}{*}{$\begin{array}{l}\text { Duração média } \\
\text { larva + pupal }\end{array}$} \\
\hline & pupas & adultos & \\
\hline Potässio & 8,8 & 7,2 & 48,3 di as \\
\hline Nitrogënio & 6,6 & 3,9 & 49,4 dias \\
\hline Testemunha & 5,5 & 2,8 & 58,4 dias \\
\hline
\end{tabular}

Qui-quadrado $=4,3619 \mathrm{n} . \mathrm{s}$.

Tabe1a 40. Sobrevivência de 600 larvas recém ećlodidas, c duração do período larva + pupa de $D$. saccharcteis, em cana planta NA56-79, adubada diferencialmente na Fazenda Patos da Usina São Josẽ ZL, SP, sct./ $/ 78$ a jan./79

\begin{tabular}{|c|c|c|c|}
\hline \multirow{2}{*}{$\begin{array}{l}\text { Adubação } \\
\text { da cana }\end{array}$} & \multicolumn{2}{|c|}{ : Sobrevivência de } & \multirow{2}{*}{$\begin{array}{l}\text { Duração mêdial } \\
\text { larva + pullal }\end{array}$} \\
\hline & pupas & adultos & \\
\hline Nitrogênio & 8,8 & 5,3 & 52,2 dias \\
\hline Potássio & 6,5 & 4,0 & 47,9 dias \\
\hline Silício & 5,5 & 4,0 & 54,6 dias \\
\hline Zinco & 4,5 & 3,7 & 55,4 dias \\
\hline Cálcio & 3,7 & 3,2 & 53,9 dias \\
\hline Fôsforo & 4,7 & 3,0 & 52,9 dias \\
\hline Testemunha & 2,5 & 2,3 & 52,1 di:as \\
\hline
\end{tabular}

Qui-quadrado $=9,3470 \mathrm{n} . \mathrm{s}$. 
Tabela 41. Sobrevivência de 500 larvas recêm ecclodidas, e duração do período 1 arva + pupa de 0 . saccharalis, em cana soca I $\Lambda \mathrm{C} 52 / 150$, adubada diferencialmente, na Fazenda Santo Antonio da Usina São José ZL, SP.out./78 a jan./79.

\begin{tabular}{|c|c|c|c|}
\hline \multirow{2}{*}{$\begin{array}{l}\text { Adubação } \\
\text { da cana }\end{array}$} & \multicolumn{2}{|c|}{ o Sobrevivência de } & \multirow{2}{*}{$\begin{array}{l}\text { Duração méclia } \\
\text { larva + pupa }\end{array}$} \\
\hline & pupas & adultos & \\
\hline Silício & 5,0 & 4,2 & 55,9 dias \\
\hline Potässio & 3,2 & 3,0 & 51,3 dials \\
\hline Nitrogênio & 3,6 & 2,8 & 58,7 dias \\
\hline Cạlcio & 2,2 & 2,2 & 53,2 dias \\
\hline Testemunha & 2,4 & 2,0 & 58,8 dias \\
\hline Fós foro & 2,2 & 1,8 & 53,1 dias \\
\hline Zinco & 2,0 & 1,8 & 57,5 dias \\
\hline
\end{tabular}

Qui-quadrado $=9,1541$ n.s.

Tabela 42. Sobrevivência e duração do periodo larva + pupa de $D$. saccharalis, em cana planta c soca CB41-76 adubada diferencialmente, no telado da CTIS. nov.l $/ 78$ a out./79

\begin{tabular}{lcccc}
\hline \multirow{2}{*}{$\begin{array}{l}\text { Adubação } \\
\text { da cana }\end{array}$} & $\begin{array}{c}\text { Larvas } \\
\text { inoculadas }\end{array}$ & \multicolumn{2}{c}{ o Sobrevivência de } & Duração médial \\
\cline { 3 - 5 } & pupos & adultos & 1arva + pupa \\
\hline Fósforo & 798 & 4,4 & 4,1 & 65,1 dias \\
Testemunha & 808 & 4,0 & 3,8 & 68,2 dias \\
Potássio & 804 & 2,7 & 2,6 & 64,9 dias \\
Nitrogênio & 816 & 2,5 & 2,4 & 67,9 dias \\
\hline
\end{tabular}

Qui-quadrado $=5,5631$ n.s. 
Em todos os casos, as diferenças de sobrevi vência não foram cstatisticamente significativas. Por outro 1ado, a duração do período larva + pupa foi qualse scmpre maior nas testemunhas, quando comparadas com os tratamentos adubados, especialmente daqueles com Potássio e Nitrogenio.

4.4.5. Testes sobre capacidade reprodutiva de 0 . saccharalis

Nas Tabelas 43,44 e 45 estão comparados os resultados obtidos nos estudos citados em 3.4.5.

Tabela 43. Resultados de 3 testes sobre capacidade reprodu tiva de $D$. saccharalis, criadas en cana planta IAC52-150 adubada diferencialmente, na liazenda Santo Antonio da Usina São José ZL, SP. Fev.$-\operatorname{mar} . / 78$.

\begin{tabular}{|c|c|c|c|c|}
\hline \multirow{2}{*}{$\begin{array}{l}\text { Adubação } \\
\text { da cana }\end{array}$} & \multirow{2}{*}{$\begin{array}{l}\text { No de } \\
\text { casais }\end{array}$} & \multicolumn{2}{|c|}{ ovos obtidos por $q$} & \multirow{2}{*}{$\begin{array}{c}\text { Viabi } 1 \text { idalde } \\
\text { : }\end{array}$} \\
\hline & & Total & Viāve is & \\
\hline Nitrogênio & 4 & 401,0 & 341,2 & 85,10 \\
\hline Potåssio & 3 & 634,3 & 521,0 & 82,13 \\
\hline Testemunha & 3 & 370,3 & 262,7 & 70,93 \\
\hline
\end{tabular}

Qui-quadrado $=26,6992 * *$ 
Tabe1a 44. Resultados de testes sobre capacidade reproduti va de 0 . saccharalis, criada em cana de 19 corte NA56-79, plantadi em 2 solos de diferentes lerti Iidades, na Usina São José ZL, SP. Mbri1/78.

\begin{tabular}{lllll}
\hline Fertilidade & No de & \multicolumn{2}{c}{ ovos obtidos por o } \\
do solo & casais & Total & Viáveis & $:$ \\
\hline
\end{tabular}

Baixa (Fazenda

Sede 14-08)

6

427,3

314,2

73,52

A1 ta (Faz. Pouso

Alegre 06-05)

4

683,5

620,0

90,71

Qui-quadrado $=58,5289 * *$

Tabela 45. Resultados de testes sobre capacidade reproduti va de $D$. saccharalis, criada em cana planta NA56-79, adubada diferencialmente na Fazenda li tos da Usina São José ZL, SP. dez./78 a fev./79

\begin{tabular}{lcccc}
\hline \multirow{2}{*}{$\begin{array}{l}\text { Adubação } \\
\text { da cana }\end{array}$} & $\begin{array}{l}\text { Nọ de } \\
\text { casais }\end{array}$ & \multicolumn{2}{c}{ ovos obtidos por 9} & Viabilidildc \\
\cline { 3 - 5 } & Total & Viáveis & \\
\hline Fósforo & 9 & 306,0 & 257,1 & 84,112 \\
Potāssio & 11 & 262,0 & 236,4 & 90,19 \\
Nitrogênio & 9 & 338,7 & 301,9 & 89,14 \\
Silício & 6 & 303,5 & 244,5 & 80,50 \\
Cálcio & 7 & 294,7 & 239,6 & 81,29 \\
Zinco & 6 & 405,5 & 277,0 & 55,98 \\
Testemunha & 5 & 279,6 & 227,8 & 81,47 \\
\hline
\end{tabular}

Qui-quadrado $=73,3351 * *$ 
Confrontando as testemunhas absolutas com os tratamentos adubados (Tabelas 43 e 45), houve diferenças marcantes, especialmente dos ovos viāveis para os tratimen tos com Potāssio e Nitrogênio. Na Tabela 45 è notório o maior nưmero de ovos por fêmea no tratamento adubado com Zinco, reduzida drasticamente pela inviabilidade desses ovos.

Quando comparados adultos criados em canas de diferentes fertilidades (Tabela 44), houve maior númcro de ovos por fêmea e maior viabilidade desses ovos na cana cu 1 tivada em solo de alta fertilidade.

4.5. Efeito da aplicação da vinhaça

4.5.1. Levantamentos de infestação final

Os resultados dos levantamentos efetuados na Usina São João, em canaviais comerciais com e sem aplicação de vinhaça diluída, estão resumidos na Tabela 46.

Nos três anos houve uma infestação maior nos canaviais que receberam vinhaça diluída por infiltração. Po rêm os dados de Intensidade de Infestação (\% de entronós broqueados), analisados pelo teste não paramétrico de Wilcoxon, deram significância estatística somente ao nível de $10 \%$. Os indices de Intensidade de Infestação, compara dos graficamente na Figura 12, mostraram diferenças constan tes e expressivas.

Os resultados de levantamentos efetuados nos 2 experimentos sobre nutrição mineral combinados com aplica ção de vinhaça nas Usinas São Carlos e Santa Adelaide, SP, estão resumidos na Tabela 47 . 
Tabela 46. Infestação final da cana pela broca, comparando canaviais irrigados com vinhaça diluída (por infiltração) e canaviais não irrigados na Usina São João, SP, 1976-78.

\begin{tabular}{|c|c|c|c|c|c|}
\hline \multirow{2}{*}{ Ano } & \multirow{2}{*}{ Tratamento } & \multirow{2}{*}{$\begin{array}{c}\text { Canas } \\
\text { Amostradas }\end{array}$} & \multicolumn{2}{|c|}{ Total Entrenós } & \multirow{2}{*}{$\begin{array}{l}\text { : Entrenós } \\
\text { broqueidos }\end{array}$} \\
\hline & & & Examinados & Broqueaclos & \\
\hline \multirow{2}{*}{1976} & Com vinhaça & 10.500 & 149.494 & 25.301 & 16,92 \\
\hline & Sem vinhaça & 163.170 & 2.664 .678 & 316.156 & 11,86 \\
\hline \multirow{2}{*}{1977} & Com vinhaça & 10.100 & 164.074 & 28.271 & 17,23 \\
\hline & Sem vinhaça & 165.880 & 2.802 .101 & 442.698 & 15,80 \\
\hline & & & & & \\
\hline \multirow{2}{*}{1978} & Cóm vinhaça & 16.500 & 295.491 & 37.651 & 12,74 \\
\hline & Sem vinhaça & 296.355 & 5.229 .944 & 510.764 & 9,77 \\
\hline \multirow{2}{*}{ Total } & Cơn vinhaça & 37.100 & 609.059 & 91.223 & 14,98 \\
\hline & Sem vinhaça & 625.405 & 10.696 .723 & 1.296 .618 & 11,87 \\
\hline
\end{tabular}

Teste de Wilcoxon $W=14(\alpha=0,10)$ 


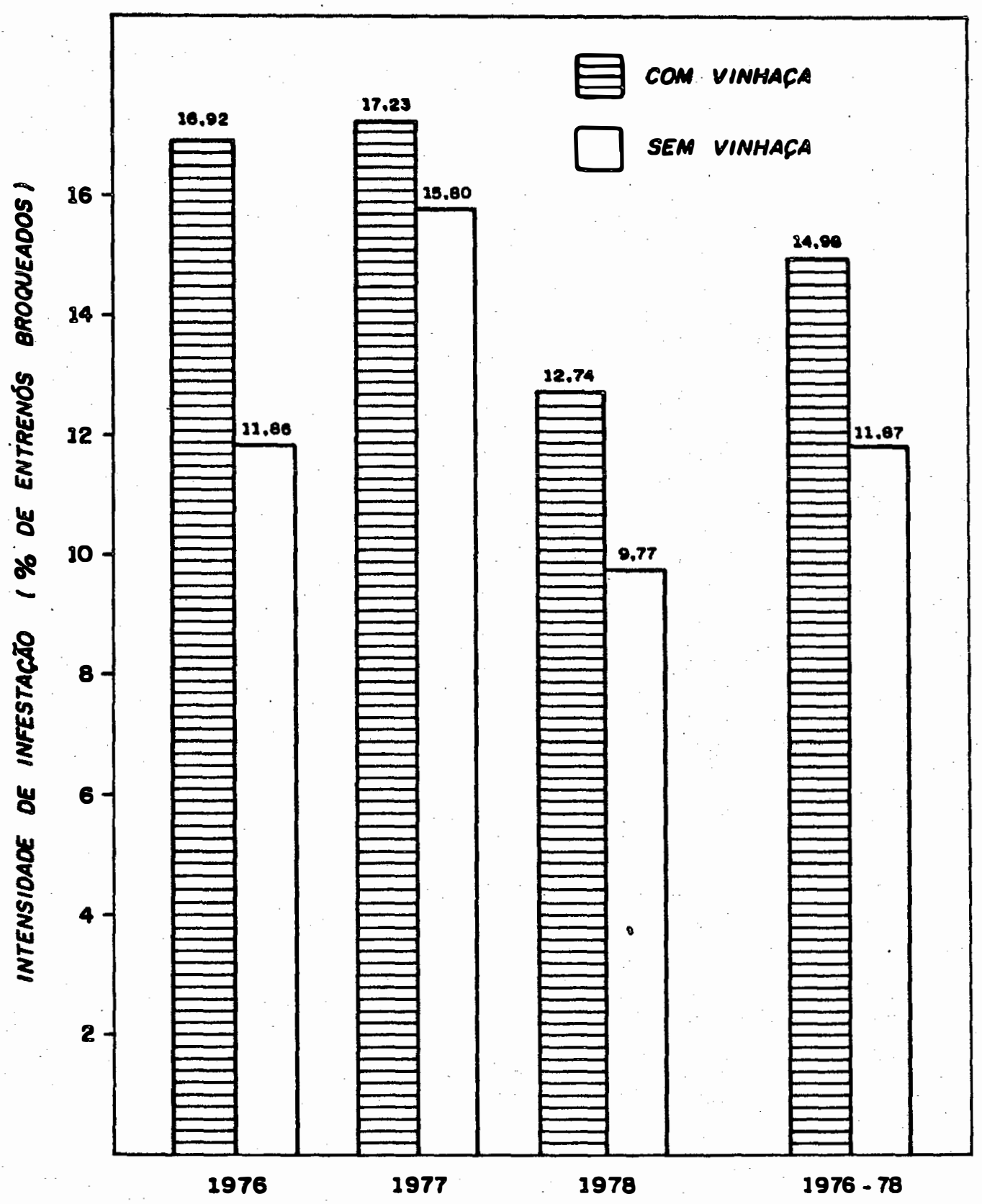

Figura 12. Efeito da oplicacão de vinhaco diluido, por infiltraçoo. sobre a infestacāo final do cano pela broca. em conoviois comerciais do Usi no Sōo Joð̄o. SP. 
Tabela 47. Infescação final da cana pela broca em 2 cxperi mentos de vinhaça e adubação, em cana NA56-79 so ca (Usina Santa Adelaide, SP) e cana CB41-76 res soca (Usina São Carlos, SP). Médias de 90 canas examinaḍas, 1978 .

Tratamento

I.I. ( (o de entrenós broqueados)

(adubação)

Sta. Adelaide

São Carlos

Média

Testemunha

9,38

8,20

8,79

NPK

10,59

8,65

9,62

Vinhaça $40 \mathrm{~m}^{3} / \mathrm{ha}$

8,26

7,96

8,11

Vinhaça $40+N P$

12,74

12,97

12,86

Vinhaça $80 \mathrm{~m}^{3} / \mathrm{ha}$

13,52

11,73

12,63

Vinhaça $80+N P$

10,19

11,30

10,75

Vinhaça $120 \mathrm{~m}^{3} / \mathrm{ha}$

13,38

12,61

13,00

Vinhaça $120+\mathrm{NP}$

11,82

15,88

13,85

Vinhaça $160 \mathrm{~m}^{3} / \mathrm{ha}$

15,64

10,79

13,22

Vinhaça $160+N P$

12,56

16,34

14,45

Vinhaça $200 \mathrm{~m}^{3} / \mathrm{ha}$

15,65

12,48

14,07

Vinhaça $200+\mathrm{NP}$

16,69

16,30

16,50 
Todas as aplicações, de vinhaça c adubação $m \underline{i}$ neral, desenvolveram infestações da broca sempre acima da testemunha absoluta, exceto naquela aplicação de $40 \mathrm{~m}^{3} / \mathrm{ha}$ de vinhaça. Observou-se também uma tendêneia de aumento des sa infestação com os aumentos da dose de vinhaça, com e sem complementação mineral, como pode ser visualizado na Fi gura 13 .

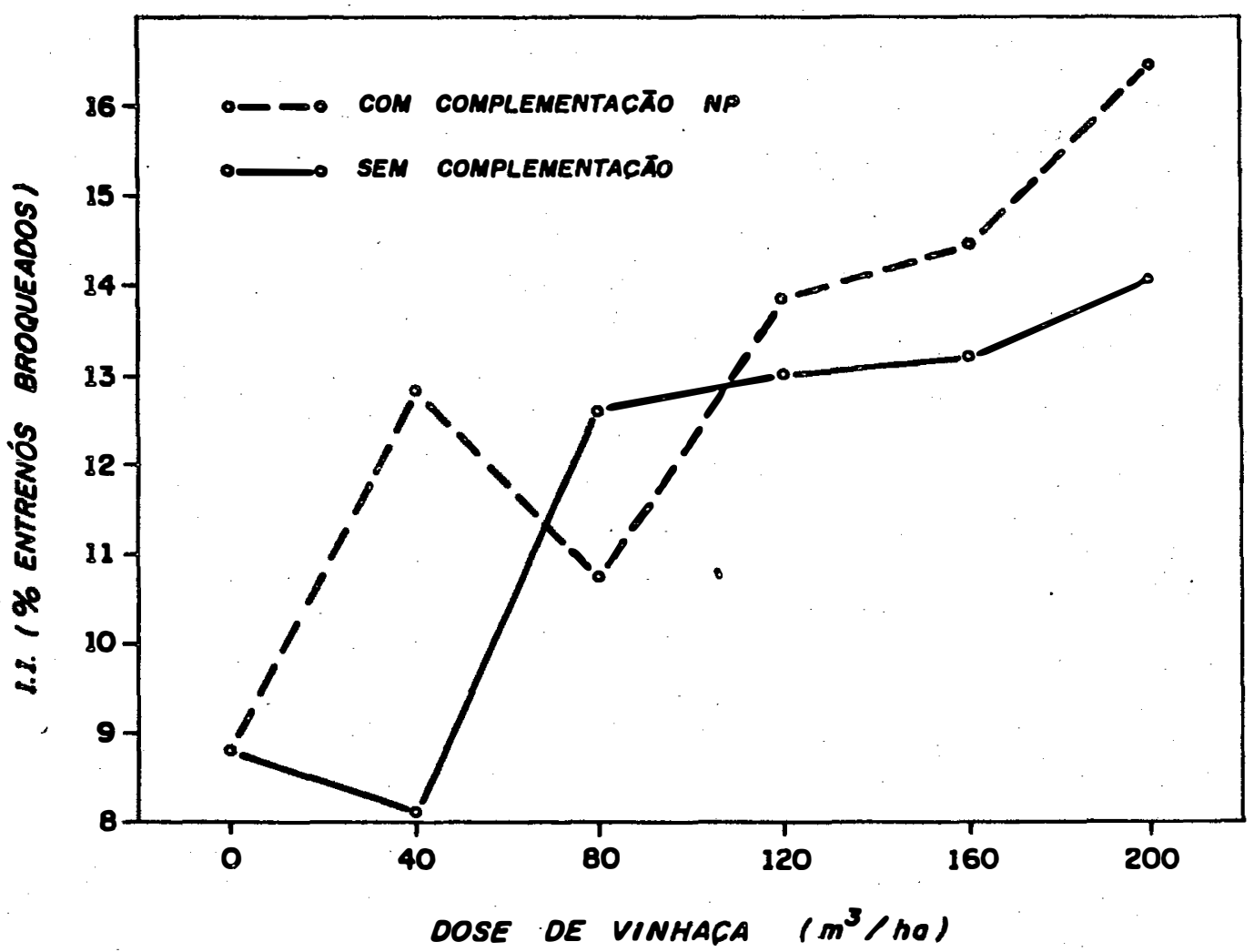

Figura 13. Relocão entre dose de vinhaca aplicada no cano, com e sem complementoção mineral NP. e suo infestacōo final pelo broca. 
A anālise de regressão demonstrou significân. cia ao nivel de $5 \%\left(r=0,8921^{*}\right)$ para a correlação entre os níveis de vinhaça aplicada e de infestaça pcla broca, re presentada pela equação $Y=8,629+0,0301 \mathrm{X}$. Para os valo res de doses de vinhaça com complementação mineral, a cor relação foi também significativa ao nível de $5:\left(r=0,9027^{*}\right)$, representada pela equação $Y=9,5517+0,0332 \mathrm{X}$ 。

Esses resultados foram praticamente repetidos nos levantamentos efetuados em 2 experimentos paralclus, como pode ser apreciado na Tabela 48.

Tabela 48. Infestação final pela broca em experimentos de vinhaça ap1icada em cana $\mathrm{CB} 41-76$ de 19 corte (ap1icação única), e de 4 o corte (aplicação acu mulada), na Usina São Carlos, SP. Médias de 150 canas examinadas por tratamento. 1979 .

Dose de vinhaça aplicada

I.I. ( $:$ de entrenós broqueados) $\mathrm{cm}$

Cana de $10^{\circ}$ corte Cana de 4 o corte

\begin{tabular}{rrr}
\hline 0 (Testemunha) & 13,06 & 6,92 \\
$40 \mathrm{~m}^{3} / \mathrm{ha}$ & 14,93 & 11,65 \\
$80 \mathrm{~m}^{3} / \mathrm{ha}$ & 16,85 & 11,58 \\
$120 \mathrm{~m}^{3} / \mathrm{ha}$ & 15,11 & 12,71 \\
\hline
\end{tabular}

Existem claras diferenças de infestaça pela broca quando confrontadas as testemunhas com os tratimentos de vinhaça. No entanto, o mais significativo desses resulta dos está no fato das diferenças serem muito maiores $\mathrm{cm}$ se tratando de aplicações acumuladas (por mais dois anos) de vinhaça, como pode ser melhor visualizado na Figura 14. 


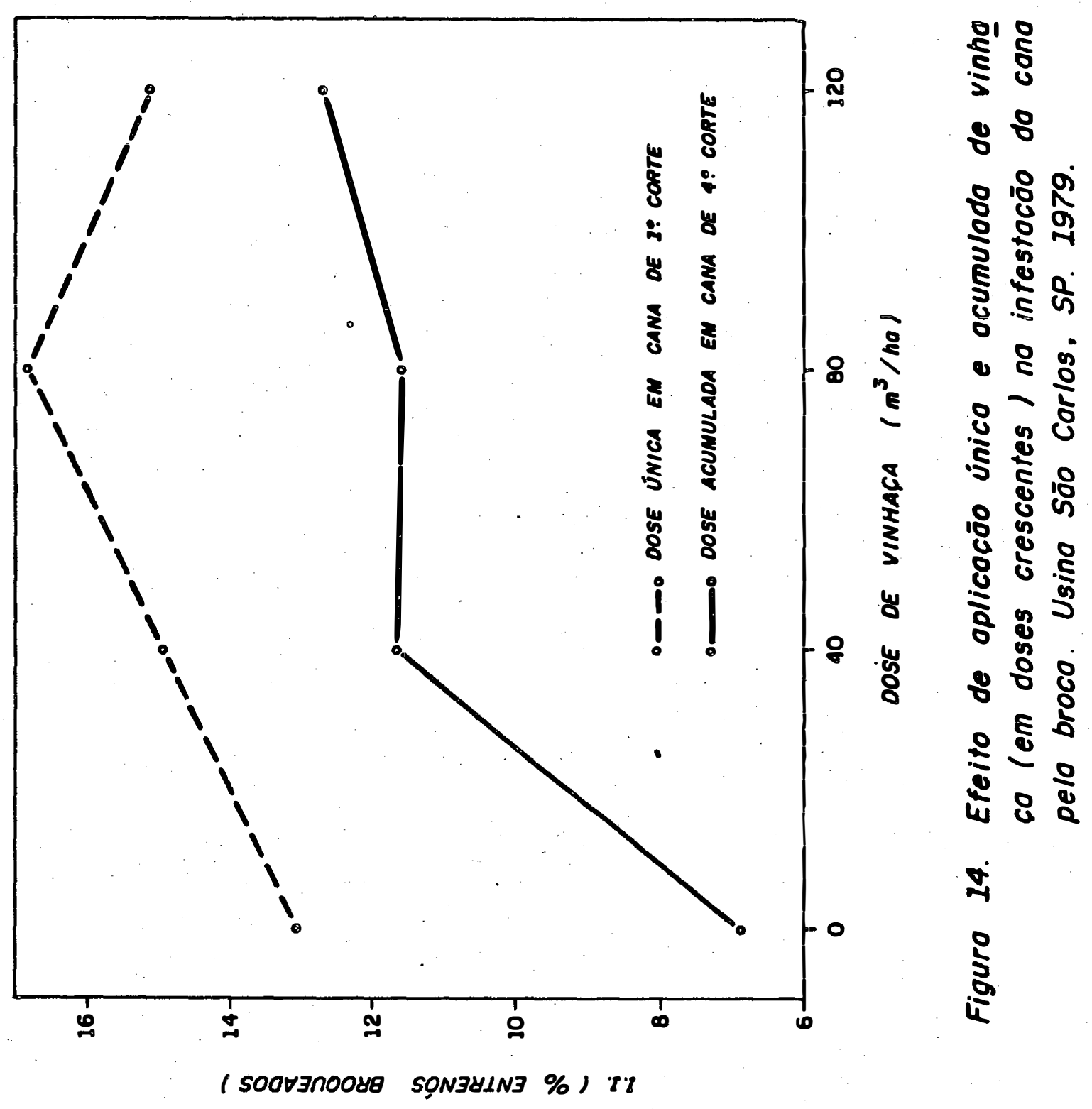


Na Tabela 49 estão comparados os resultados de levantamentos efetuados em 2 talhões comerciais, com c sem aplicação de vinhaça.

Tabela 49. Infestação final causada pela broca em cana irri gada (por 2 anos) com vinhaça comparada a uma testemunha, em 200 canas amostradas por tratimen to, Cana NA56-79 de 39 corte. Usina Barra lirande, SP, 1980 .

\begin{tabular}{lcccc}
\hline $\begin{array}{l}\text { Aplicação } \\
\text { de vinhaça }\end{array}$ & $\begin{array}{c}\vdots \text { o canas } \\
\text { broqueadas }\end{array}$ & Examinados & Broqueados & \multirow{2}{*}{$\begin{array}{c}\text { Total entrenós } \\
\text { broqucialos }\end{array}$} \\
\hline $148 \mathrm{~m}^{3} / \mathrm{ha}$ em & 77,5 & 4.121 & 381 & 9,25 \\
2 anos & & & & \\
0 (Testemunha) & 63,0 & 4.138 & 285 & 6,89 \\
\hline
\end{tabular}

Qui-quadrado $=15,4845^{* *}$

As diferenças de infestação foram visíveis, confirmadas pela anālise estatístiça, sendo esta maior no canavial que recebeu vinhaça durante 2 anos consecutivos.

\subsubsection{Levantamentos populacionais}

Os resultados desses levantamentos cfetualos em 2 talhões comerciais da Usina Barra Grande, estão rela cionados nas Tabelas 50 e 51 . 
Tabela 50. Densidade populacional relativa da broca (coleta por hora/homem) em cana NA56-79 de 39 corte, com e sem irrigação de vinhaça. Usina Barra ciran de, SP, 1979-80。

Vinhaça

irrigada

\begin{tabular}{lllllll}
\hline Sim & 34,0 & 22,7 & 29,0 & 28,1 & 24,7 & 27,7 \\
Não & 25,0 & 17,0 & 24,3 & 28,3 & 19,5 & 22,8 \\
\hline Médias & 29,5 & 19,8 & 26,6 & 28,2 & 22,1 & \\
\hline
\end{tabular}

Teste não paramétrico de Wilcoxon: $W=34(\alpha=0,10)$.

Tabela 51. Parasitismo $\left(\begin{array}{l}0 \\ 0\end{array}\right)$ de brocas coletadas cm ciana NA56-79 de 30 corte, com e sem irrigação de vi. nhaça. Usina Barra Graṇde, SP, 1979-80.

\begin{tabular}{lrrrrr}
\hline Vinhaça & \multicolumn{5}{c}{ Idade da cana em meses } \\
\cline { 2 - 6 } irrigada & 3 & 4 & 5,5 & 6,5 & 7,5 \\
\hline Sim & 32,7 & 44,3 & 68,6 & 86,5 & 77,4 \\
Não & 39,5 & 43,4 & 74,4 & 84,1 & 77,3 \\
\hline
\end{tabular}

Teste não paramétrico de Wilcoxon: $W=28 \mathrm{n} . \mathrm{s}$.

Em geral, houve maior densidade populacional relativa na cana irrigada com vinhaça (Tabcla 50), porém, essa diferença foi significativa estatisticamente somente ao nível de $10 \%$ de probabilidade. Por outro lado, näo foram detectadas diferenças nos valores de parasitisho das brocas. 
4.5.3. Testes de controle natural de ovos da broca

A Tabela 52 compara os resultados obtidos em 3 testes conduzidos dentro de 2 talhöes comerciais de cana.

Tabela 52. Controle natural (induzido) de ovos de D. saccharalis, em cana NA56-79 de 39 corte, com e sem irrigação de vinhaça. Usina Barra Grande, SP. out./79 a jun./80.

\begin{tabular}{|c|c|c|c|c|c|}
\hline \multirow{2}{*}{$\begin{array}{l}\text { Vinhaça } \\
\text { irrigada }\end{array}$} & \multirow{2}{*}{$\begin{array}{l}\text { ovos } \\
\text { expostos }\end{array}$} & \multicolumn{3}{|c|}{ \% de ovos } & \multirow{2}{*}{$\begin{array}{c}\text { Controle } \\
\text { natura } 1 \\
:\end{array}$} \\
\hline & & parasitados & mastigados & sugaulos & \\
\hline $\operatorname{Sim}$ & 129 & 2,3 & 49,6 & 20,2 & 72,09 \\
\hline Não & 117 & 6,8 & 45,3 & 22,2 & 74,36 \\
\hline
\end{tabular}

Qui-quadrado $=0,1604 \mathrm{n.s}$.

Não houve diferenças significativas, quando comparadas à cana irrigada com a testemunha.

4.5.4. Testes sobre capacidade reprodutiva de 0 . saccharalis

Os resultados de 13 testes conduzidos com o material biológico coletado dos canaviais com e sem aplica ção de vinhaça na Usina Barra Grande, estão apresentados na Tabela 53 . 
Tabela 53. Resultados de 13 testes sobre capacidacle repro dutiva de $D$. saccharalis, criada em canaviais com e sem irrigação de vinhaça na Usina Barra Grande, SP. Fevereiro-Março/80

\begin{tabular}{|c|c|c|c|c|}
\hline \multirow{2}{*}{$\begin{array}{l}\text { Vinhaça } \\
\text { irrigada }\end{array}$} & \multirow{2}{*}{$\begin{array}{l}\text { No de } \\
\text { casais }\end{array}$} & \multicolumn{2}{|c|}{ ovos obtidos por ? } & \multirow{2}{*}{ Viabi $\underset{i}{i}$} \\
\hline & & Total & Viāveis & \\
\hline Sim & 42 & 224,8 & 154,9 & 68,89 \\
\hline Não & 20 & 183,3 & 140,6 & 76,70 \\
\hline
\end{tabular}

Qui-quadrado $=2,9214 \mathrm{n} . \mathrm{s}$.

Neste caso, houve maior número de ovos produ zidos por fêmeas criadas em cana irrigada coni vinhaça. No entantó, houve menor viabilidade desses ovos nesse tratil mento. Portanto, a análise estatística não mostrou signi ficância quando considerados os valores de ovos viáveis. 


\section{DISCUŚSÃO}

\subsection{Idade do canavial}

Os resultados apresentados na Tabela 1 e na Figura 5, mostram uma decisiva influência da idade do cun vial (corte) sobre a infestação final causada pela broca, sendo clara a tendência de diminuição da infestação com o "envelhecimento" do canavial, coincidindo com uma das con clusões de MACEDO et alii (1978). No entanto, esta influên cia pode ser alterada por outros fatores que modifiquem substancialmente o estado fisiológico dos canaviais, tais como abundantes e balanceadas adubações, aplicação intens $\underline{i}$ va de vinhaça e variedades utilizadas, como serā discutido posteriormente.

Procurando exp1icações para este fato, obsc $\underline{r}$ va-se que as populações das fases imaturas da broca tendem a diminuir com o "envelhecimento" do canavial (Figura (o), sen do provável que isto seja conscquência de uma maior mortal dade dos ovos (4.1.3.) e estágios, iniciais da broca nos cal naviais de mais idade e não pelo parasitismo das brocas de senvolvidas (Figura 7). 
O controle natural dos ovos da broca, calusado por parasitos e predadores, é uma das causas que exnlica as diferenças de infestação, quando comparados canaviais de diferentes cortes (Tabelas 5 e 6 ). As populações de parasi tos e predadores são mais atuantes nos canaviais de maior idade, sendo tambëm bastante evidente a maior atuação dos predadores mastigadores em todos os casos. Estas obscrva ções coincidem com aquelas relatadas por REAGAN (1981) na Louisiana.

Apesar de não ter dado significância estatís tica quando confrontados os dados de sobrevivência das bro cas inoculadas artificialmente em canaviais de difcrentes idades (Tabela 7), esta foi um pouco maior na cana planta e essa pequena diferença poderia ser importante no descnvol vimento posterior das populações da broca e sua infestação à cana. A duração do período larva + pupa desses indivícluos sobreviventes mostrou ser menor em canas de primeiro cortc, explicando também, em parte, a maior infestação registrada nestes canaviais de primeiro corte. Isto equivale ao maior número de gerações que poderā ocorrer em canaviais mais novos, quando comparados à canaviais mais velhos.

No entanto, as diferenças mais visiveis foram registradas na capacidade reprodutiva das populações da bro ca criadas em canaviais de diferentes idades (Tabelas 8 c9). Isto significa que essa fertilidade dos adultos criados cm canaviais de diferentes idades é uma das principais causas das diferenças de infestação registradas.

A associação dos fatores mencionados cxnlicam essa diminuição de infestação com o avanço de idade do ca navial, sendo o maior responsāvel a diminuição de potencial 
biótico da broca, tanto em termos de capacidadc reprodutiva dos adultos, como no alongamento do ciclo biológico que, no final, resulta em menos nümero de gerações durante o ciclo vegetativo da cana. Este fato, auxiliado pelo maior contro le natural dos ovos, especialmente pelos predadores, pare cem explicar essa diminuição das infestações da broca em canaviais mais "velhos"。

\subsection{Idade da cana}

Conforme os resultados apresentados na Tabcla 10 e na Figura 8, oxiste uma marcante correlaça positiva entre a idade da cana e sua infestação final causadi pela broca, explicando o fato de maior incidencia la brocil nas canas "bisadas" (deixadas sem cortar de um ano para outro), e nas canas de primeiro corte chamadas de canas de "ano e meio" que permanecem vegetando no campo uma média de 10 a 18 meses. Esta correlação pode ser explicada teoricamente pelo maior nümero de gerações da broca nas canas com períoclos vegetativos mais longos.

A anālise dos resultádos de levantamentos po pulacionais em canas de diferentes idades (Tabelas $11,12 \mathrm{c}$ 13, e Figuras 9 e 10) revelaram aumento da densidade popu lacional apenas no caso dos valores da Usina Barra Cirande à medida que aumentava o crescimento da cana. Por outro $1 \underline{\mathrm{a}}$ do, observou-se diminuição do parasitismo larval da broca com o aumento de idade da cana, nos resultados das Usinas Barra Grande e Santa Cruz S.A. Esses dados cxplicam, em parte, os aumentos de infestação final registrados cm canas de períodos vegetativos mais longos.

Os resultados cxpressos nas Tabclas 14 c 15 , indicando maior parasitismo e predação de ovos da broca cm 
canas mais crescidas, podem ser explicados pela cessaçio dos tratos culturais que podem ter perturbado esses inimi gos naturais (especialmente os predadores) nos primciros mc ses de crescimento da cana.

Apesar de não ter-se demonstrado diferenças significativas na sobrevivência e duração do período $1 \mathrm{ar}$ va + pupa de $D$. saccharalis ( Tabela 16), houve uma maior sobrevivência atê o estado adulto nas canas mais crescidas, que podem explicar, em parte, a maior infestação final que acontece em canas com maior período vegetativo.

No entanto, a explicação mais admissíve1, pâ ra o fato de maior infestação em canas com períodos vegeta tivos mais longos, deve ser devido ao maior número de gera çōes da broca nesses canaviais.

\subsection{Variedades de cana}

Os resultados originais apresentados no apền dice II e aqueles apresentados nas Tabelas 17, 18 e 19 re velam diferenças bastante marcantes da infestação final at in gida pela broca nas diferentes variedades estudadas. Porém, existem variações na posição de cada variedade na ordem des sas diferenças em cada ano. Apesar dessas variações na or dem, existem variedades que em todos os casos estiveram sem pre acima da média de I.I. (Intensidade de Infestação) quan do comparadas pelo IC 5\% (Intervalo de Confiança)

(IAC52/ 150, IAC58/480, NA56-79, CP51-22 e IAC51/205), enquanto outras estiveram sempre abaixo dessa média (CB47-355, CB49-62, IAC50/134, Co740, Co775 e IAC48/65). Portanto, cssas varicda des podem ser consideradas como suscetíveis c resistentes, respectivamente. 
- teste de Tukey, que apenas detecta as va riedades diferiram significativamente, confirma tambëm cssa classificação, desde que em 1978 (Tabcla 17) a variclade IAC52/150 (suscetível) diferiu significativamente das virie dades IAC50/134, Co740 e IAC48/65 (resistentes). Em 1980 (Tabela 18) a variedade IAC58/480 (suscetível) diferiu da variedade Co775 (resistente).Em 1981 (Tabela 19) essa di ferença tornou-se mais evidente comparando a variedide CP51-22 (suscetíve1) com a variedade CB47-355 (resistente).

O comportamento de algumas dessas varicliales confirma observaçẽes anteriores relatadas pelo PLAN (1975, 1977, 1978 e 1979), e especialmente por MACliDO it alii (1978), onde também são incluídas CB45-155 c CB56-156 entre as variedades resistentes e CB41-76 entre as viric dades suscetiveis.

Pelos resultados apresentados na Tabela 20, pode-se incorporar a variedade CB40-13 entre as variedades suscetíveis à broca, e a SP70-1499 entre as variedades re sistentes, confirmando-se tambēm o comportamento de resís tência para a variedade CB47-355.

Esse comportamento varietal, em termos dc densidade populacional de formas imaturas durante o cresc mento das canas, se confirma em alguns casos como na Usina Barra Grande (Tabela 21) onde manifestou-se maior densidacle populacional nas variedades suscetíveis I $\Lambda$ C $52 / 150$, I $/(51 / 205$ e NA56-79, quando comparadas com a variedade resistente IAC48/65, acontecendo o conträrio na comparação dos pil ra sitismos larvais da broca. Na Usina Santa Cruz S. 4 . ('liabe 1a 23) as variedades suscetíve is Ci'51-22, N $456-79$ IAC52-150 mostraram também maiores densidades populacionais da broca quando comparados com a variedade 
CB47-355, porém sem diferenças perceptíveis no que se role re ao parasitismo. Esse comportamento foi também obscrvado nos resultados da Tabela 24, onde a densidade populacionil nas variedades suscetíveis IAC52/150 e CB40-13 foi milior quando comparada com a variedade resistente CB47-355, porém sem tendências definidas nas diferenças de parasitismo. És ses resultados tendem a guardar alguma relação entre "sus cetibilidade" da variedade com maior densidade populacional de formas imaturas da broca. Por outro lado, essa reliçio com respeito ao parasitismo larval da broca esta inclefin da, não só em termos de parasitismo total como tambëm na composição específica desse parasitismo.

As diferenças no controle natural dos ovos dia broca em 4 variedades de cana (Tabela 25) não contribuem lia ra explicar o comportamento dessas variedades em relação a sua infestação final.

Os resultados comparativos das Tabelas 26 e 27 mostram maiores sobrevivências na variedade suscetível NA56-79, mesmo sem serem significativas estatisticamentc, verificando-se tambēm uma menor duração mẻdia do período larva + pupa. Esses dados podem explicar parcialmentc a maior infestação final desta variedade. Para a variclade resistente IAC48/65 verificou-se menor sobrevivência c maior duração do período larva + pupa de 0 . saccharalis, ex plicando também parcialmente o comportamento desta viricila de em relação a sua menor infestação final por esta praga. Jã os resultados da Tabela 28 , não contribuíram para expli car o comportamento das variedades comparadas, em termos de sobrevivência e duração do período larva + pupa.

Por outro 1ado, quando comparada a capacidalle reprodutiva dos adultos criados nessas variedales ('Tahela 
29), verifica-se que a variedade IAC52/150 proporcionou o maior número de ovos viāveis por fêmea, explicando assim a maior infestação final atingida pcla broca nesta variclialc suscetível. O conträrio aconteceu com a variedade CB47-355, que causou um menor número de ovos viáveis por fêmea, cxpli cando também a menor infestação final causada pcla broca nesta variedade resistente.

\subsection{Estado nutricional da cana}

Os resultados apresentados nas Tabelas 30,31 e 32 demonstram uma notável influência da adubação da cana sobre a infestação final causada pela broca. Todas as adu bações, exceto aquela do micronutrientc zinco (Tabcla 32), causaram sempre infestações maiores que na Testemunha abso luta (sem adubação alguma), coincidindo neste sentido com resultados de outros levantamentos extensivos, TERÂN (1979b). Porém, as maiores infestações com o micronutricnte silício (Tabela 32) contrariam os resultados de DJAMIN e PATIINK (1969), obtidos com este micronutriente em arroz, estudando a infestação por uma broca semelhap̧te porém de outro gênc ro (Chilo).

Pelos resultados da Tabela 30 e Figura 11, po. de-se ainda observar que a adubação da cana com doses cres centes dos 3 macronutrientes, causaram diferentes tendên cias na infestação final pela broca. A adubação potássici cm doses crescentes mostrou uma clara correlaça positiva, de tectada estatisticamente, com o aumento de infestação peli broca. Aconteceu tambēm uma correlação similar com as do ses crescentes de Nitrogênio, mas com uma queda na milior dose que poderia ter sido causada pelo desequilíbrio nutri cional criado com outros nutrientes. Por outro lado, a di minuição de infestação com as doses crescentes de lísforo 
detectada tambếm estatisticamente, deverå ser ainda pesqui sada isoladamente, especialmente do ponto de vista de sua interação no balanço nutricional da cana.

Estes resultados são, sem düvida, bastante significativos, demonstrando infestações sempre maiores em canaviais adubados, faltando apenas determinar a influên cia das diversas interações dos nutrientes considerados.

Quanto à densidade populacional de formas ima turas da broca, embora os resultados totais (Tabela 33) te nham mostrado concordância com os resultados de infestacio final (Tabela 32), estas não foram significativas quando os dados foram separados para as 3 datas de coleta l'abela 34). Aconteceu o mesmo com os valores de parasitismo larval das brocas (Tabela 35). Portanto, apesar de terem-se regis trado maiores densidades populacionais e parasitismos lar vais nos canaviais adubados com os nutrientes estudados, es tas não foram significativas e não contribuíram para expli car as maiores infestações finais atingidas em canaviais adubados.

0 menor controle natural de ovos da broca $\mathrm{cm}$ canavial melhor nutrido (Tabela 36) e em canaviais adubados com diversos nutrientes (Tabela 38) contribuem para expli car parcialmente o maior sucesso das populações infestantes da broca nesses canaviais. Esse menor controle natural $\mathrm{cm}$ canas mais nutridas e/ou adubadas, possivelmente seja devi do ao abrigo que estes canaviais bem fechados ofereçam i broca, prejudicando a ação dos parasitos e predadorcs los ovos da broca.

Os resultados de sobrevivência e de duracián do período larva + pupa de 0 . saccharalis (4.4.4.) nĩo de 
monstraram ser significativamente diferentes para os diver sos tratamentos adubados. Porém, apesar dessa falta de ré sultados significativos, foi detectada menor sobrevivencia (Tabelas 39 e 40) e maior duração do período larva + pul)a (Tabelas 39, 41 e 42) nas parcelas não adubadas (Testemu nhas absolutas). Esses resultados podem ser de alguma impor tância para explicar a maior infestação final causada por esta praga nos tratamentos adubados.

A maior capacidade reprodutiva (represcntidia pelo maior número de ovos viāveis) dos adultos de 0 . saccharalis criados em canas adubadas (Tabclas 43 c 45), ou em canas melhor nutridas (Tabela 44), ê, sem düvida, o lia tor mais importante para explicar as maiores infestacoses li. nais causadas por esta praga em canaviais bem nutriclos.

Os resultados apresentados na Tabela 45 , mo $\underline{s}$ tram um comportamento único da capacidade reprodutiva da broca no tratamento com o macronutriente Zinco. Nesse ciso, obteve-se o maior número de ovos por fêmea, porêm a viabi lidade desses ovos foi notoriamente baixa, sugerindo alguma interferência desse nutriente na fertilidade das populacoos de 0 . saccharalis.

\subsection{Efeitos da aplicação de vinhaça}

Pelos resultados apresentados em $4.5 .1 .$, po de-se verificar, sem dúvida, um grande aumento de inlesta ção final causado pela broca em canaviais irrigados com $v \underline{i}$ nhaça diluída ou concentrada.

A aplicação de vinhaça diluída em canavialis comerciais causou infestacõos sempre maiores nos 3 anos cs tudados, comparando-os com canaviais vizinhos sem essa lor 
tirrigação (Tabela 46 e Figura 12). Como a quantidade aplicą da por infiltração em sulcos foi volumosa, o cfeito pode ser atribuído a irrigação mais do que a nutrição, confirminn do nesse caso os resultados relatados por MENDEs et al $i i$ (1976b) sobre o efeito de irrigação da cana na infestaça pela broca.

Já nos outros casos, com vinhaça pura, aplicie da na concentração em que é produzida nas destilarias ('l'ä belas $47, .48$ e 49), o efeito pode ser devido, mais a nutri ção da cana, especialmente a adubação potãssica, descle que este é bastante rico nesse macronutriente. Esse cfeito parc ce confirmar-se nos casos de aumento de doses de vinhaça aplicada (Figuras 13 e 14 ), onde existe um claro alumcinto de infestação com o incremento das doses aplicildas, compor tamento semelhante àquele obtido com as doses crescentes de Potässio (Figura 11). No ültimo caso (Figura 14) obsc $\underline{r}$ va-se tambëm diferenças mais marcantes entre a Testcmunha e as aplicações acumuladas de vinhaça (por anos consccutivos), fato que também foi repetido nos resultados da Tabcla 49, cuja parcela tratada com vinhaça corresponde a aplical ção acumulada de 2 anos.

A diferença de infestação foi apenas percept í ve1, no primeiro ano de aplicação de vinhaça, enquanto que após a segunda aplicação de vinhaça, a diferença de infestạ ção foi significativa.

A anālise de resultados dos levantamentos po pulacionais (Tabelas 50 e 51 ) revelam pequenas dilcrencis na densidade populacional de rormas imaturas da broca que explicariam parcialmente as diferenças de infestação. Por outro lado, essas aplicações de vinhaça parecem não alterar o desenvolvimento dos parasitos larvais da brocia. 
Os resultados resumidos nas Tabelas 52 e $5 \tilde{3}$, contribuem pouco para explicar a maior infestação final re gistrada nas parcelas com vinhaça, jă que as diferenças não foram significativas. No entanto, o aumento de infes tação final registrado em canaviais que receberam aplicação de vinhaça (normalmente soqueiras) deverä alterar a redução de infestação com o avanço da idade do canavial (4.1.1.) es pecialmente se continuarem as aplicações gencralizadas de vinhaça nos canaviais comerciais.

\subsection{Observações gerais}

Nos diversos testes de sobrevivência cfetua dos sob condições naturais observaram-se muitas variasócs na sobrevivência das fases imaturas atê atingir o cstágio adulto, com resultados variāveis de $1,0 \%$ (Tabela 7) até $7,2 \%$ (Tabela 39), porém, em condições protegidas por tclado, essa sobrevivência foi maior, chegando at $\vec{e} 13,9 \%$ (Tabc1a 26). Esses valores estão bastante próximos daqueles relata dos por GUEVARA (1976). Uma grande variação foi também ob servada para os valores de duração das fases larvais e da crisālida, com valores desde 44,3 dias (Tabela 7) até 68,2 dias (Tabela 42).

Pelos estudos comparativos de controle nat $\underline{u}$ ral de ovos, observa-se que este é um fator de controlc mui to importante na redução natura1 das populaçõcs de 0 . saccharalis. Esse controle natural variou desde um minimo de 56,25\% (Tabela 15) até um máximo de 100\% (Tabela 37). lis sas variações devem ser bastante decisivas para determinar a infestação final causada por esta praga da cana.

Essas variações também foram registradas no parasitismo larval da broca, variando desde 17,5\% (Tabela 
11) atë $86,5 \%$ (Tabela 51).

Portanto, todas essas variações devem ser ob servadas previamente, em canas imaturas, para decidir so bre a necessidade de reforcar o controle natural da broca, que ê bastante importante para estabelecer qualquer esque ma de manejo integrado de 0 . saccharalis em canaviais comcr ciais de uma Usina ou região produtora. 


\section{CONCLUSOES}

Pela anålise global dos resultados discutidos conclui-se que existem suficientes evidências acumuladas so bre alguns fatores predisponentes do hospedeiro para altas infestações da cana pela Diatraea saccharalis (Fabr. 1794).

Esse conhecimento facilita o direcionamento dos trabalhos de monitoramento, necessários para o mancjo integrado deste inseto-praga.

Esse direcionamento e̊ fundamental para atin gir resultados tēcnico-econômicos em canaviais cxtensos c diversificados de uma usina ou região canavicira.

$$
\text { Entre os fatores estudados, destacam-sc }
$$

os

seguintes:

- A idade do canavial tem marcada influencia na infestacióo final pela broca, o qual diminui com o envelhecimento da cultura.

- A capacidade reprodutiva da broca diminui em canaviais mais velhos, acontecendo o inverso com o controle natural 
dos ovos da broca.

- A idade da cana no momento da colheita tem marcada inlluên cia na infestação final da broca, sendo esta maior nas ca nas de periodos vegetativos mais longos.

- Apesar das variações na "suscetibilidade" ou "resistên cia" das variedades de cana, existe clara tendência le a $\underline{1}$ gumas variedades serem sempre mais infestadas pela broca, como CP51-22, NA56-79, IAC52/150, IAC51/205 e IAC58/480; enquanto que outras mostram clara tendência a sercm me nos infestadas, como Co740, IAC50/134, CB47-355, IAC48/65, CB49-62 e Co775.

- Existe uma visível influência do estado nutricional da cana sobre a infestação final pela broca. Em cana adubada, ocorre sempre maior infestação.

- A infestação tende a aumentar com doses crescentes de Pó tāssio e Nitrogênio, faltando ainda definir a influência da interação de nutrientes na infestação da broca.

- Alguns micronutrientes influem nesta infestação, notada mente o $\mathrm{Zn}$ que interfere na fertilidade da broca.

- A principal causa das maiores infestações è o aumento da capacidade reprodutiva das brocas criadas nesses cana viais adubados.

- A vinhaça aplicada nos canaviais (especialmente cm soyuci ras) aumenta a infestação final causada pela broca, sendo esta maior com doses crescentes ou acumuladas de vinhaça. Ocorre uma interação (ação conjunta) de irrigação (" nutri ção com relạ̧ão ao ataque da praga. 
- A aplicação de vinhaça e adubação das soqueiras sĩo os principais fatores modificadores da tendência de reclução de infestação com o avanço de idade do canavial. 


\section{LITERATURA CITADA}

ALAM, M.M., 1980. Biological and ecological factors affecting populations of sugarcane moth-borcr, Diatraca saccharalis (Lep.: Pyralidae) in Barbados, W.I. Lntomo phaga.Paris, 25(4): 401-414.

ALAM, M.M., F.D. BENNET e K.P. CARL, 1971. Biological control of Diatraea saccharalis (F) in Barbados by Apanteles flavipes Cam. and Lixophaga diatraeae T. Entomophaga. Paris, 16(2) : 151-158.

BENNETT, F.D., 1969. Tachinid flies as biological control a gents for sugarcane moth borer.'In: WILLIAMIS, J.R.; J.R. METCALFE, R.W. MUNGOMERY e R. MATHES, Eds. Pests of Sugar Cane. Amsterdam. Elsevier Publishing Company, p. 117-148.

BOTELHO, P.S.M.; A.C. MENDES; N. MACEDO e S. SILVEIRA NIT'O, $1978 \mathrm{a}$. Influences of climatic factors on the populations of the sugarcane moth borer, Diatraea saccharalis (Fabr., 1794) (Lep. - Crambidae). In: Procecdings 16th Congress: ISSCT. São Paulo, p. 643-655.

BOTELHO, P.S.M.; A.C. MENDES; N. MACEDO E S. SILVI:IRA NI:TO, 1978 b. Cálculo da dispersão da broca da cana-de-aćúcirr, Diatraea saccharalis (Fabr., 1794). Brasil Acuciarciro, Rio 
ELLISOR, L.C. e J.W. INGRAM, 1939. Experiments with insecti cides in the control of the sugarcane borer, Diatraca saccharalis (F). In: Proceedings 6th Congress ISSC.'. Baton Rouge, La: p. 693-705.

FLINT, M.L. e R. van den BOSCH, 1981. Introduction to Intc, grated Pest Management. New York, Plenum Press. 240 p.

GALLO, D., 1952. Contribuição para o controle biológico da broca da cana-de-açúcar. Ana is da ESALQ - USP. Piracicialia, $\underline{9}: 135-142$.

GALLO, D., 1980. Situação do controle biológico da brocia da cana-de-açúcar no Brasil. Anais da SEB. Jaboticabal, $\underline{9}$ (2) : 303-308.

GRAVENA, S.; J.R. SANGUINO e J.R. BARA, 1980. Controle bio lógico da broca da cana Diatraea saccharalis (Fabr., 1794) por predadores de ovos e Bacillus thuringiensis Berliner. Anais da SEB. Jaboticabal, $\underline{9}(1):$ 87-95.

GUAGLIUMI, P., 1962. Las Plagas de 1a Caña de Azucar en Ve nezuela ( 2 tomos). Ministério da Agricultura Y Ciria. Maracay, Venezuela.p. 850 .

GUAGLIUMI, P., 1973. Pragas da Cana de Açúcar (Nordestc do Brasil). IAA, Rio de Janeiro, Brasil. (Colcção canavie i ra no 10) $622 \mathrm{p}$.

GUEVARA, L.A.C., 1976. Aspectos da Biologia cm Condiçócs Na

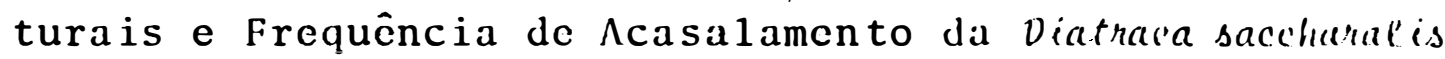
(Fabr. , 1794) (Lepidoptcra: Crambidac) ^ Broca dal lialla de Açúcar. Piracicaba, ISSLQ/USP, 70 p. (Disscrtilciáo de Mestrado). 
de Janeiro, 92(12): 9-14.

BOX, H.E., 1926. Sugarcane moth borers (Diatraca spp) in British Guiana. Bulletin of Entomological Research. London, 16: 249-266.

BOX, H.E., 1947. Informe preliminar sobre los taladraclores de la caña de azucar (Diatraea spp) em Venezucla. Bolctim Técnico Ministério da $\Lambda$ gricultura Y Cria. Maracay $117 \mathrm{p}$.

CASTILHO, H.J., 1982. Introdução de Apanteles flavipes (Cam ., 1891) (Hymenoptera, Braconidae) para o controlc biológ co da broca da cana-de-açúcar Diatraea saccharalis (Fibr., 1794)(Lepidoptera, Pyralidae), na região de Santa Bärba ra D'Oeste, SP, Piracicaba, ESALQ/USP, 79 p. (Disscrta ção, de Mestrado).

CHARPENTIER, L.J.; J.R.GIFFORD; T.E. SUMMERS A R.D. JACKSON, 1971. Biological control of sugarcane insects in conti nental United States - A historical review. In: Procecdings $14 \mathrm{th}$ Congress ISSCT. Baton Rouge, Louisiana, p. 466-476.

DEGASPARI, N., P.S.M. BOTELHO e N. MACEDO, 1981. Controle químico da Diatraea saccharalis em cana-de-açúcar, nal re gião centro-sul do Brasil. Boletim Técnico Planalsucar. Araras, $\underline{3}(6): 5-16$.

DJAMIN, A. e M.D. PATHiAK, 1967. Role of silica in Resistance to Asiatic rice borcr, Chilo suppresalis (Walker), in rice varieties. Journal of [iconomic Entomology. College Park, Maryland, 60(2): 347-351.

路

DUGAS, A.L., 1956. Recommendations for the control of sugarcine borer in Louisiana. Sugar Bull ctin. New ()rleans, 34: 191-192. 
HENSLEY, S.D., 1971 a. Management of sugarcane borer popul il tions in Louisiana, a decade of change. Entomophaga. Paris, 16 : 133-146.

HENSLEY, S.D., 1971 b. Control of the sugarcane borer, Diatraea saccharalis (F.) in Louisiana. In: Procecdings. 14 th Congress ISSCT. Baton Rouge, Louisiana, p. 453-4(1)1.

HENSLEY, S.D. e A.H. HAMMOND . 1968. Laboratory techniques for rearing the sugarcane borer on an artificial diet. Journal of Economic Entomology. College Park, Maryland, $\underline{61}(6): 1742-1743$.

HENSLEY, S.D.; E.J. CONCIENNE; W.J. MCCORMICK e. I...J. CHARPENTIER. 1968. Recent developments in insecticialil control of the sugarcane borer in Louisiana. In: Procec. dings 13 th Congress ISSCT. Taipei, Taiwan, p. 1365-1.308.

HOLLOWAY, T.E.; W.E. HALEY; U.C. LOFTIN C C. HEINRICH, 1928. The sugarcane moth borer in the United States. Washington, D.C., USDA Tech. Bul1. no 41. 7? p.

KING, E.G.; J. SANFORD; J.W. SMITH e D.F.MARTIN, 1981. Augmentative release of Lixophaga diatracae. (1)ip.;

Tachinidae) for suppression of early - scason su garcane borer populations in Louisiana.

Entomophagal.

Paris, 26 (1): 59-69.

KNIPLING, E.F., 1972. Simulated population models to appraise the potential for suppressing sugarcane borer populations by strategic relcases of the parasite Lixophaga dialnasac. Environmental Entomology。 College Park, Maryland, I (1): $1-6$. 
LONG, W.H. e S.D. HENSLEY, 1972. Insect Pests of sugarcane. Annual Review of Entomology. Palo Alto, California, 17: 149-176.

LONG, W.H.; F.J. CONCIFNNE; S.D. HENSLEY; W.J. MCCORMICK e L.D. NEWSOM, 1959. Control of the sugarcane borer with insecticides. Journal Economic Entomology. College lark, Maryland, $\underline{52}(5): 821-824$.

LONG, W.H.; J.M.M.WALDER; R.B. SGRILLO e F.M. WIENDL. 1976. - Basis for the use of insecticide in management of populations of the sugarcane borer Diatraca saccharalis (F.) in São Paulo State, Brazil. Sugar y Azucar. New York, $\underline{71}(12): 25-34$.

MACEDO, N.; A.C. MENDES e P.S.M.BOTELHO. 1978. Susceptibility of the main commercial sugarcane varieties to the moth borer, Diatraea saccharalis (Fabr., 1794), in the southern central Brazil. Proceedings 16 th Congress ISSCT. São Paulo.p. 693-701.

MARTORELL, L.F. e S. MEDINA G., 1965. Notes on parasitism of the sugarcane moth borer, Diatraea saccharalis (Filbr.) in Puerto rican sugarcane fields. Procecdings $12 \mathrm{th}$. Congress ISSCT. San Juan, p. 1295-1303.

MATTOS,A.0.; G. CALCAGNOLO e D.A. Oliveira, 1976. Resulta dos de ensa ios visando o controle quím ico da Diatracia saccharalis (Fabr., 1794) em cana-de-acúcar. São Paulo, Instituto Biolögico. $2 \mathrm{p}$.

MATTOS, A.0., 1982. Contribuição ao Estudo do Controle inte grado da Broca da Cana-de-açúcar, Diatraea sacchanal' is (Fabr., 1794) (Lepidoptera, Pyralidae). piracicalia, 
ESALQ/USP, 64 p. (Dissertação Mestrado)

MENDES, A.C.; P.S.M. BOTELHO c N. M $\Lambda$ CEDO, 1976 b. Efeitos da irrigação na infestação da Diatraca saccharalis (I.., $1794)$ em cana-de-açúcar. Brasil Açucarciro. Rio de Janei ro, $\underline{87}(5): 15-19$.

MENDES, A.C., P.S.M. BOTELIIO e N. MACEDO, 1978. Altura do vôo, hora do vôo e influência das fases lunares sobre a captura de adultos da Diatraea saccharalis (Fabr., 1794) atravēs de armadilhas luminosas. Brasil Açucarciro. Rio de Janeiro, $\underline{9} 2(11): 21-33$.

MENDES, A.C.; P.S.M. BOTELHO, S. SILVEIRA NI:TO e N. MAC:Iildo, 1976 a. Seleção de luzes de diferentes comprimentos de onda para atração de broca da cana-de-açúcar, Diatraea saccharalis (Fabr., 1794) (Lep. - Crambidac. Brasil Acu careiro. Rio de Janeiro, $\underline{88}(8)$ : 38-45.

MENDES, A.C.; P.S.M. BOTELHO; N. MACEDO e N.A. LAVORENII, 1980 Correlation between the intensity of infestation and population index of the sugarcanc borcr, Diatraca saccharalis (Fabr., 1794): Procecdings 17th Congress ISSCT. Manila, Filipinas, p. 1719-1730.

MISKIMEN, G.W. 1962. Studies of the biological control of Diatraea saccharalis F. (Lepidoptera: Crambidac) on St. Croix, U.S. Virgin Islands. Journal of Agriculturc University of Puerto Rico. San Juin, $46(2): 135-13 !)$. 
NEGM, A.A. e S.D. HENSLEY, 1971. Role of predacious arthro pods of the sugarcane borer, Diatraca saccharalis (I.) in Louisiana. Proceedings 14th Congress ISSCT. New Orleans, p. 445-453.

NEVES, E.J.L., 1981. Metodologia de aplicação de inscticí : das granulados para ensaio de manejo integrado da broca da cana Diatraea saccharalis (Fabricius, 1794). Jabot caba1, UNESP, 63 p. (Dissertação de Mestraclo).

PHERSON, E.M. e S.D. HENSLEY, 1976. Potential of Lixophaga diatraeae for control of Diatraca saccharalis in loulisi na. Journal of Economic Entomology. College Park, Marylind, $\underline{69}(2): 215-818$.

PLANALSUCAR, 1972. Relatório anual. Rio de Janeiro, p. 22-23. PLANALSUCAR, 1973. Relatório anua1. Rio de Janeiro, p. 40-46. PLANALSUCAR, 1974. Relatọ́rio anual. Piracicaba, p. 32-46. PLANALSUCAR, 1975. Relatório anuậ. Piracicaba, p. 43-54. PLANALSUCAR, 1976. Relatório anua1. Piracicaba, p. 33-40. PLANALSUCAR, 1977. Relatório anua 1. Piracicaba, p. 26-37. PLANALSUCAR, 1978. Relatório anua1. Piracicaba, p. 22-25. PLANALSUCAR, 1979. Relatório anua1. Piracicaba, p. 21-23. PLANÁLSUCAR, 1980. Relatório anual. Piracicabà, p. 21-22. 
RAIGOSA B., J.D., 1976. Comunicação pessoal.

REAGAN, T.E., 1981. A pest management system for sugarcane insects. Louisiana Agriculture. 24(2) : 12-14.

RICE, E.R., 1981. Biological-chemical control of sugarcane borers in Florida. Sugar Journal. New Orleans, $43(9)$ : 17-19.

RISCO, S.H., 1954. La mosca indigena Paratheresia claripalpis W. en el control biológico de Diatraca saccharalis, Fabr. en el Perú. Lima-Perú. Pub1. del Comitc de Prod. de Azucar. $31 \mathrm{pp}$.

SANFORD, J.W., 1976. Inherited sterility in progeny of irradiated male sugarcane borers. Journal of Economic Entomology. College Park, Maryland, 69(4) : 456-468.

SCARAMUZZA, L.C., 1946. Control Biológico del borer o per forador de la caña de azucar en Cuba, por medio de 1a mosca Lixophaga. Memorias 19a Conferencia Anual Asociacion Tecnicos Azucareros. Cuba, Habảna. p. 11-17.

SGRILLO, R.B., 1973. Criação em laboratório da Broca da Ca na de Açúcar (Diatraea saccharalis - Fabricius, visando o seu controle. Piracicaba, ESALQ/USP, 99 p. (I) i sertação de Mestrado).

SGRILLO, R.B., 1979. Desenvolvimento de modelo Matemitico para a população da broca da cana-de-açúcar, vialraca saccharalis (Fabr., 1794) e Simulação da Técnica do Ind víduo Esteril. Piracicaba, LSALQ/USp, 189 p. (Tese de Doutoramento). 
SIMMONDS, F.J., 1955. Establishment of parasites of Diatraca saccharalis $F$. in Dominica (British west Indies) and Guadeloupe (French west Indices). Tropical Agriculture. Trinidad, W. I. $\underline{32}$ : 198-200.

SIMMONDS, F.J., 1959. The succesful biological control of the sugarcane moth borer, Diatraca saccharalis F. (I.c)i doptera, Pyralidae) in Guadeloupc, B.W.I. Procecdings. 10th. Congress ISSCT. Ilawaii, pp.914-919.

SOLOMON, M.E., 1973. Ecology in relation to the management of insects. In: Geicr et alii., eds. Insccts, studics in population management p. 1-16.

SOUZA, H.D., 1942. A broca da cana de açúcar c seus parasi tos em Campos, Estado do Rio de Janeiro. Boletim no 4, Ministério da Agricultura, Rio de Janeiro. 22 .

SUMMERS T.E.; E.G. KING, D.F. MARTIN e R.D. JACKSON, 1976. Biological control of Diatraea saccharalis in Florida by periodic releases of Lixophaga diatraeae. Entomophaga, Paris, $\underline{4}$ : 359-366.

TERÂN, F.O., 1976. Perspectivas do controle biológico da broca da cana-de-açúcar, Boletim Técnico Copersuciar. Sĩo Paulo, $\underline{2} / 76: 5-9$ 。

TERÃN, F.0., 1979 a. Dinâmica populacional de adultos de Diatraea saccharalis (Fabr., 1794) em canaviais do lista do de São Paulo. Anais da S.E. B. Jaboticabal, $\underline{8}(1): 3-17$.

TERAN, F.0. 1979 b. Sugarcanc nutrition modiries infestation by Diatraea spp. ISSCT Entomology Newsletter. Araris, 6 : 20-23. 
TERÃN, F.0. 1980 a. Natural control of Diarraca saccha'alis (Fabr., 1794) eggs in sugarcane ficlds of São Paulo. Proceedings $17 \mathrm{th}$ Congress ISSCT. Manila, Filipinas, p. $1704-1714$.

TERAN, F.O., 1980 b. Densidade larval de Diatraca saccharalis e seu controle natural em milho. In: 60 Cong. Brasileiro de Entomologia, Campinas, SP. p. 323-324. (Resumo).

TERÁN, F.O., e W.R.T. NOVARETT I 1978. Management of popu lations of Diatraea saccharalis (Fabr., 1794) (Lepidopte ra: Crambidae) in sugarcane fields of São Paulo, Brazil. Proceedings 16th Congress ISSCT, São Paulo, p. 671-687.

TERÃN, F.O., e W.R.T. NOVARETTI, 1980 a. Mancjo integrado da broca da cana de açūcar nas usinas cooperadas. Boletim Técnico Copersucar, São Paulo, 11/80:9-10.

TERÁN, F.O. e W.R.T. NOVARETTI, 1980 b. Resultados econômi cos do manejo integrado da broca da cana-dc-açúcar. Bole tim Técnico Copersucar. São Paulo. 12/80:9-12.

WALDER, J.M.M., 1976. Estudo da população da Diatraéa saccharalis (Fabr., 1794) em Quatro Regiões Canaviciras do Estado de São Paulo. Piracicaba, ESALQ/USP. 111 p. (Te se de Doutoramento).

WALKER D.W., V. QUINTANA e J. TORRES, 1971. Genet ic collipste of insect populations. 1. Extinction of inbred and out bread 1 ines in laboratory populations of the sugarcalne borer. Journal I:conomic I:ntomology. College Park, Marylind $\underline{64}(3)$ : $660-667$. 
WILLIAMS, J.R.; J.R. METCALFE; R.W. MUNGOMILRY e R. MA'TIII:S, Eds., 1969. Pests of sugarcane. New York, Amstcrdiul. E1sevier Pub1. Co. 568 p. 
8. APENDICE 
8.1. Apêndice I 


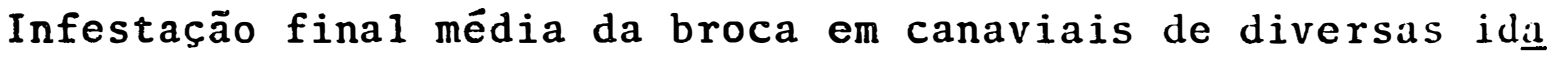
des, no Estado de São Paulo, em 1977

\begin{tabular}{|c|c|c|c|c|c|}
\hline $\begin{array}{l}\text { Corte (idade } \\
\text { do canavial) }\end{array}$ & $\begin{array}{l}\text { Locais } \\
\text { (Usinas) }\end{array}$ & $\begin{array}{c}\text { Canas } \\
\text { Amostradas }\end{array}$ & $\frac{\text { Total }}{\text { Examinados }}$ & $\frac{\text { Entrenōs }}{\text { Brociados }}$ & $\begin{array}{l}\text { : Entrenós } \\
\text { brocialos }\end{array}$ \\
\hline $1 \%$ & 6 & 329.978 & 6.403 .083 & 840.574 & 13,13 \\
\hline 29 & 6 & 307.049 & 5.246 .953 & 600.929 & 11,45 \\
\hline 39 & 6 & 235.199 & 3.853 .056 & 405.140 & 10,51 \\
\hline 49 & 5 & 126.600 & 2.030 .880 & 217.046 & 10,69 \\
\hline 50 & 4 & 15.050 & 248.729 & 29.153 & 11,72 \\
\hline 60 & 3 & 4.000 & 69.636 & 5.886 & 8,45 \\
\hline 79 & 1 & 700 & 10.494 & 575 & 5,78 \\
\hline
\end{tabular}


Infestação final média da broca em canaviais de diversas ida des, no Estado de São Paulo, em 1978

\begin{tabular}{|c|c|c|c|c|c|}
\hline \multirow{2}{*}{$\begin{array}{l}\text { Corte (idade } \\
\text { do canavial) }\end{array}$} & \multirow{2}{*}{$\begin{array}{l}\text { Locais } \\
\text { (Usinas) }\end{array}$} & \multirow{2}{*}{$\begin{array}{c}\text { Canas } \\
\text { Amostradas }\end{array}$} & \multicolumn{2}{|c|}{ Total Entrenós } & \multirow{2}{*}{$\begin{array}{l}\text { : Lintrenós } \\
\text { brociados }\end{array}$} \\
\hline & & & Examinados & Brocados & \\
\hline 10 & $14^{\circ}$ & 520.153 & 10.511 .568 & 1.178 .407 & 11,21 \\
\hline 29 & 12 & 528.840 & 9.271 .512 & 697.361 & 7,52 \\
\hline 39 & 11 & 421.026 & 7.276 .637 & 453.322 & 6,23 \\
\hline 40 & 10 & 278.360 & 4.522 .462 & 242.276 & 5,36 \\
\hline 50 & 9 & 48.635 & 737.606 & 46.459 & 6,30 \\
\hline 60 & 6 & 3.750 & 59.820 & 4.754 & 7,95 \\
\hline 70 & 4 & 4.898 & 82.340 & 4.014 & 4,87 \\
\hline $8 \%$ & 1 & 300 & . 5.015 & 73 & 1,46 \\
\hline
\end{tabular}


Infestação final mẻdia da broca em canaviais de diversas ida deś, no Estado de São Paulo, em 1979

\begin{tabular}{|c|c|c|c|c|c|}
\hline $\begin{array}{l}\text { Corte (idade } \\
\text { do canavial) }\end{array}$ & $\begin{array}{l}\text { Locais } \\
\text { (Usinas) }\end{array}$ & $\begin{array}{c}\text { Canas } \\
\text { Amostradas }\end{array}$ & $\frac{\text { Total }}{\text { Examinados }}$ & $\frac{\text { Entrenós }}{\text { Brocialos }}$ & $\begin{array}{l}\text { : Tint renós } \\
\text { brocialos }\end{array}$ \\
\hline 10 & 21 & 595.638 & 11.474 .998 & 1.297 .629 & 11,31 \\
\hline 29 & 18 & 664.656 & 11.424 .445 & 888.273 & 7,78 \\
\hline 39 & 18 & 537.936 & 8.353 .037 & 510.318 & 5,76 \\
\hline $40^{\circ}$ & 16 & 361.537 & 5.704 .353 & 333.338 & 5,84 \\
\hline 50 & 12 & 60.369 & 948.172 & 45.445 & 4,79 \\
\hline 69 & 11 & 23.650 & 377.816 & 22.126 & 5,86 \\
\hline 79 & 3 & 1.450 & 23.270 & 908 & 3,90 \\
\hline 89 & 1 & 400 & 7.236 & 114 & 1,57 \\
\hline
\end{tabular}


Infestação final média da broca em canaviais de diversas idâ des, no Estado de São Paulo, em 1980

\begin{tabular}{|c|c|c|c|c|c|}
\hline \multirow{2}{*}{$\begin{array}{l}\text { Corte (idade } \\
\text { do canavial) }\end{array}$} & \multirow{2}{*}{$\begin{array}{l}\text { Locais } \\
\text { (Usinas) }\end{array}$} & \multirow{2}{*}{$\begin{array}{c}\text { Canas } \\
\text { Amostradas }\end{array}$} & \multicolumn{2}{|c|}{ Total Canas } & \multirow{2}{*}{$\begin{array}{l}\text { : Int renós } \\
\text { brocialos }\end{array}$} \\
\hline & & & Fxaminados & Brocados & \\
\hline 10 & 27 & 766.881 & 15.236 .237 & 2.042 .432 & $1.3,(1)$ \\
\hline 29 & 27 & 764.148 & 13.397 .326 & 1.380 .918 & 10,31 \\
\hline 39 & 27 & 793.782 & 13.433 .119 & 1.120 .916 & 8,34 \\
\hline 49 & 27 & 565.601 & 9.466 .109 & 655.871 & 0,92 \\
\hline 50 & 21 & 188.841 & 3.158 .812 & 219.770 & 6,95 \\
\hline 69 & 16 & 42.344 & 701.077 & 45.687 & 6,52 \\
\hline 79 & 9 & 17.445 & 280.475 & 20.705 & 7,38 \\
\hline 89 & 6 & 5.165 & 79.425 & 4.875 & 6,14 \\
\hline 99 & 6 & 5.005 & 77.986 & 4.949 & 6,35 \\
\hline 109 & 3 & 4.705 & 68.748 & 1.906 & 2,77 \\
\hline 119 & 1 & 400 & 5.505 & 243 & 4,41 \\
\hline 129 & 1 & 30 & 489 & 9 & 1,84 \\
\hline
\end{tabular}


Infestação final média da broca em canaviais de diversas idal des, no Estado de São Paulo, em 1981

\begin{tabular}{|c|c|c|c|c|c|}
\hline \multirow{2}{*}{$\begin{array}{l}\text { Corte (idade } \\
\text { do canavia1) }\end{array}$} & \multirow{2}{*}{$\begin{array}{l}\text { Locais } \\
\text { (Usinas) }\end{array}$} & \multirow{2}{*}{$\begin{array}{c}\text { Cannas } \\
\text { Amostradas }\end{array}$} & \multicolumn{2}{|c|}{ Total Entrenós } & \multirow{2}{*}{$\begin{array}{l}\text { ¿ Tintrenós } \\
\text { brociados }\end{array}$} \\
\hline & & & Examinados & Brociados & \\
\hline 19 & 23 & 877.052 & 17.017 .183 & 1.691 .982 & 9,94 \\
\hline 29 & 22 & 787.974 & 13.253 .657 & 1.062 .66 .3 & 8,02 \\
\hline 39 & 22 & 760.940 & 12.020 .080 & 779.044 & 6,48 \\
\hline 49 & 22 & 568.781 & 8.811 .715 & 552.678 & 6,27 \\
\hline 59 & 18 & 299.174 & 4.626 .907 & 248.990 & 5,38 \\
\hline 69 & 13 & 60.404 & 969.454 & 35.970 & 3,71 \\
\hline 79 & 12 & 16.084 & 234.164 & 13.134 & 5,61 \\
\hline 89 & 6 & 12.334 & 178.325 & 13.021 & 7,30 \\
\hline 90 & 5 & 4.132 & 59.931 & 4.125 & 6,88 \\
\hline 109 & 3 & 2.271 & 33.197 & 1.111 & 3,15 \\
\hline 119 & 1 & 230 & 3.088 & 104 & 3,37 \\
\hline
\end{tabular}


8.2. Apêndice I I

o 
Infestação final média da broca, nas variedades de cana co merciais mais plantadas no Estado de São Paulo em 1977

\begin{tabular}{|c|c|c|c|c|c|}
\hline \multirow{2}{*}{ Variedade } & \multirow{2}{*}{$\begin{array}{l}\text { Locais } \\
\text { (Usinas) }\end{array}$} & \multirow{2}{*}{$\begin{array}{c}\text { Canas } \\
\text { amostradas }\end{array}$} & \multicolumn{2}{|c|}{ Total Entrenós } & \multirow{2}{*}{$\begin{array}{l}\text { o Fintrenós } \\
\text { brocialos }\end{array}$} \\
\hline & & & Examinados & Brocados & \\
\hline CB41-76 & 9 & 401.934 & 7.142 .366 & 809.550 & 11,33 \\
\hline NA56-79 & 9 & 182.505 & 3.228 .263 & 4.37 .375 & 13,55 \\
\hline CB47-355 & 9 & 43.698 & 693.298 & 50.561 & 7,29 \\
\hline CB40-13 & 8 & 50.686 & 880.314 & 114.892 & 13,05 \\
\hline IAC52/150 & 8 & 29.485 & 587.223 & 76.080 & 12,96 \\
\hline CB46-47 & 6 & 27.111 & 447.402 & 48.536 & 10,85 \\
\hline CB41-14 & 5 & 74.078 & 1.285 .077 & 177.527 & 13,81 \\
\hline IAC51/205 & 5 & 42.345 & 762.155 & 93.451 & 12,26 \\
\hline IAC52/326 & 5 & 8.903 & 187.758 & 26.307 & 14,01 \\
\hline IAC48/65 & 4 & 60.197 & 974.104 & 117.160 & 12,03 \\
\hline Co740 & 4 & 18.791 & 343.183 & 18.898 & 5,51 \\
\hline CB49-260 & 4 & 4.750 & 86.646 & 8.069 & 9,31 \\
\hline
\end{tabular}


Infestação final mêdia da broca nas variedades de cana comer ciais mais plantadas no Estado de São Paulo, em 1978

\begin{tabular}{|c|c|c|c|c|c|}
\hline Variedade & $\begin{array}{l}\text { Locais } \\
\text { (Usinas) }\end{array}$ & $\begin{array}{c}\text { Canas } \\
\text { Amostradas }\end{array}$ & $\frac{\text { Total }}{\text { Examinados }}$ & $\frac{\text { ntrenós }}{\text { Brocados }}$ & $\begin{array}{l}\text { : Ent renós } \\
\text { brocialos }\end{array}$ \\
\hline CB41-76 & 14 & 636.239 & 11.774 .655 & 861.689 & 7,32 \\
\hline NA56-79 & 14 & 463.025 & 8.653 .857 & 832.313 & 9,62 \\
\hline IAC52/150 & 14 & 84.688 & 1.606 .023 & 159.151 & 9,91 \\
\hline CB40-13 & $12^{\circ}$ & 103.385 & 1.862 .111 & 195.092 & 10,48 \\
\hline CB47-355 & 11. & 44.580 & 759.104 & 34.911 & 4,60 \\
\hline CB46-47 & 9 & 33.150 & 503.582 & 31678 & 6,29 \\
\hline IAC51/205 & 8 & 122.600 & 2.190 .986 & 167.432 & 7,61 \\
\hline CB41-14 & 8 & 86.495 & 1.583 .403 & 139.957 & 8,84 \\
\hline Co740 & 8 & 55.200 & 1.088 .035 & 57.810 & 5,31 \\
\hline CB49-260 & 8 & 49.699 & 952.347 & 44.102 & 4,63 \\
\hline IAC48/65 & 7 & 106.662 & 1.776 .727 & 88.521 & 4,98 \\
\hline CB49-62 & 7 & 26.957 & 461.255 & 16.617 & $3,(0)$ \\
\hline CB56-126 & 7 & 12.348 & 227.141 & 12.614 & $5, .55$ \\
\hline IAC $50 / 1 \cdot 34$ & 6 & 16.400 & 291.445 & 8.594 & 2,95 \\
\hline IAC52/179 & 6 & 9.350 & 142.938 & 5.654 & 3,96 \\
\hline IAC52/326 & 6 & 7.700 & 138.504 & 11.997 & 8,66 \\
\hline CB36-24 & 4 & 14.650 & 306.657 & 17.086 & $5 ., 57$ \\
\hline CP51-22 & 4 & 4.740 & 132.086 & 8.068 & 6,56 \\
\hline
\end{tabular}


Infestação final mêdia da broca nas variedades de cana comer ciais mais plantadas no Estado de São Paulo, em 1979

\begin{tabular}{|c|c|c|c|c|c|}
\hline \multirow{2}{*}{ Variedade } & \multirow{2}{*}{$\begin{array}{l}\text { Locais } \\
\text { (Usinas) }\end{array}$} & \multirow{2}{*}{$\begin{array}{c}\text { Canas } \\
\text { Amostradas }\end{array}$} & \multicolumn{2}{|c|}{ Tota1 Entronós } & \multirow{2}{*}{$\begin{array}{l}\text { : Entrenós } \\
\text { brociados }\end{array}$} \\
\hline & & & Examinados & Brocados & \\
\hline NA56-79 & 17 & 697.340 & 12.534 .474 & 1.237 .217 & 9,87 \\
\hline IAC52/150 & 17 & 133.697 & 2.245 .299 & 209.550 & 9,33 \\
\hline CB41-76 & 16 & 403.301 & 6.680 .030 & 509.085 & 7,62 \\
\hline CB $47-355$ & 15 & 30.983 & 496.613 & 25.117 & 5,06 \\
\hline CB40-13 & 14 & 47.762 & 786.365 & 47.658 & 6,06 \\
\hline CB56-126 & 13 & 12.012 & 205.933 & 14.637 & 7,11 \\
\hline IAC51/205 & 11 & 54.447 & 938.941 & 54.493 & 5,80 \\
\hline CB41-14 & 9 & 95.085 & 1.496 .281 & 168.448 & 11,26 \\
\hline CB46-47 & 9 & 18.587 & 316.869 & 16.736 & 5,28 \\
\hline CB53-98 & 9 & 13.251 & 211.671 & 21.395 & 10,11 \\
\hline Co740 & 8 & 35.450 & 633.325 & 21.422 & 3,38 \\
\hline IAC48/65 & 8 & 82.960 & 1.315 .427 & 101.662 & $7 ; 73$ \\
\hline IAC58/480 & 7. & 10.520 & 188.134 & 7.821 & 4,16 \\
\hline CP51-22 & 7 & 12.884 & 234.597 & 11.083 & 4,72 \\
\hline IAC52/326 & 6 & 9.010 & 136.112 & 8.075 & 5,93 \\
\hline CB49-62 & 6 & 7.475 & 116.933 & 3.257 & 2,79 \\
\hline CB49-260 & 5 & 52.700 & 864.088 & 33.762 & 3,91 \\
\hline IAC52/179 & 4 & 1.250 & 20.283 & 664 & 3,27 \\
\hline CB47-89 & 4 & 1.013 & 21.111 & 3.387 & 16,04 \\
\hline
\end{tabular}


Infestação final mêdia da broca nas variedades comcrcialis de cana mais plantadas no Estado de São Paulo, em 1981

\begin{tabular}{|c|c|c|c|c|c|}
\hline \multirow{2}{*}{ Variedade } & \multirow{2}{*}{$\begin{array}{l}\text { Locais } \\
\text { (Usinas) }\end{array}$} & \multirow{2}{*}{$\begin{array}{c}\text { Canas } \\
\text { Amostradas }\end{array}$} & \multicolumn{2}{|c|}{ Total Entrenós } & \multirow{2}{*}{$\begin{array}{c}\text { o Entrenós } \\
\text { Brocialos }\end{array}$} \\
\hline & & & Examinados & Brocaados & \\
\hline NA56-79 & 25 & 1.578 .569 & 27.132 .987 & 2.132 .987 & 7,71 \\
\hline IAC52/150 & 25 & 404.339 & 8.115 .698 & 762.028 & 9,39 \\
\hline CB47-355 & 23 & 62.896 & 992.480 & 58.709 & 5,92 \\
\hline CB41-76 & 19 & 410.351 & 6.416 .909 & 415.984 & 0,48 \\
\hline IAC51/205 & 18 & 126.601 & 2.163 .056 & 148.297 & 6,86 \\
\hline CB53-98 & 17 & 49.130 & 775.571 & 52.368 & 6,75 \\
\hline CP51-22 & 17 & 29.984 & 537.689 & 57.553 & 10,70 \\
\hline IAC58/480 & 17 & 17.274 & 301.410 & 27.420 & 9,10 \\
\hline CB41-14 & 15 & 152.546 & 2.424 .656 & 190.280 & 7,85 \\
\hline IAC48/65 & 15 & 110.065 & 1.769 .734 & 144.991 & 8,19 \\
\hline CB40-13 & 12 & 63.926 & 1.177 .151 & 110.278 & $9,37^{\circ}$ \\
\hline CB56-126 & 10 & 13.190 & 191.521 & 12.694 & 6,63 \\
\hline SP70-1143 & 10 & 5.350 & 92.482 & 9.373 & 10,13 \\
\hline CB47-89 & 9 & 11.819 & 180.374 & 10.188 & 5,65 \\
\hline Co740 & 8 & 62.273 & 935.307 & 24.620 & 2,03 \\
\hline CB46-47 & 8 & 14.807 & 247.302 & 21.479 & 8,69 \\
\hline CB49-62 & 8 & 6.061 & 94.454 & 5.727 & 6,06 \\
\hline SP70-1005 & 8 & 5.700 & 93.868 & 6.297 & 6,71 \\
\hline CB49-260 & 7 & 41.893 & 595.967 & $.44: 659$ & 7,19 \\
\hline SP70-1078 & 7 & 3.041 & 55.741 & 4.199 & 7,53 \\
\hline SP70-1284 & 6 & 1.640 & 27.314 & 1.010 & 3,70 \\
\hline CB45-155 & 5 & 227.410 & 3.902 .493 & 257.255 & 6,59 \\
\hline IAC52/179 & 5 & 5.460 & 94.227 & 6.222 & 0,00 \\
\hline Co775 & 5 & 1.664 & 30.835 & 2.764 & 8,96 \\
\hline SP70-3370 & 5 & 900 & 16.525 & 1.190 & 7,20 \\
\hline CB56-86 & 4 & 1.753 & 28.108 & 1.876 & 6,67 \\
\hline IAC52/326 & 4 & 1.634 & 25.202 & 1.494 & 5,93 \\
\hline
\end{tabular}


Infestação final média da broca, nas variedades de cana co merciais mais plantadas no Estado de São Paulo, em 1980

\begin{tabular}{|c|c|c|c|c|c|}
\hline \multirow{2}{*}{ Variedade } & \multirow{2}{*}{$\begin{array}{l}\text { Locais } \\
\text { (Usinas) }\end{array}$} & \multirow{2}{*}{$\begin{array}{c}\text { Canas } \\
\text { Amostradas }\end{array}$} & \multicolumn{2}{|c|}{ Total Entrenós } & \multirow{2}{*}{$\begin{array}{l}\text { : Fint renós } \\
\text { brocialos }\end{array}$} \\
\hline & & & Examinados & Brocados & \\
\hline NA56-79 & 27 & 1.110 .313 & 20.464 .353 & 2.104 .242 & 10,28 \\
\hline CB41-76 & 25 & 567.759 & 9.497 .222 & 808.505 & 8,51 \\
\hline IAC52/150 & 25 & 281.847 & 4.731 .084 & 507.912 & 10,74 \\
\hline CB47-355 & 23 & 68.167 & 1.054 .968 & 69.527 & $(0,59)$ \\
\hline IAC51/205 & 20 & 115.865 & 2.107 .366 & 214.829 & 10,19 \\
\hline CB53-98 & 17 & 35.676 . & 588.945 & 49.943 & 8,48 \\
\hline IAC58/480 & 16 & 20.971 & 362.734 & 28.465 & 7,85 \\
\hline IAC48/65 & 15 & 83.431 & 1.367 .298 & 138.523 & 10,13 \\
\hline CB40-13 & 14 . & 86.092 & 1.680 .535 & 196.410 & 11,62 \\
\hline CB56-126 & 14 & 22.972 & 362.726 & 38.976 & 10,75 \\
\hline CP51-22 & 14 & 21.421 & 394.507 & 44.193 & 11,20 \\
\hline CB41-14 & 12 & 62.892 & 1.290 .513 & 161.430 & 12,51 \\
\hline CB49-260 & 11 & 101.882 & 1.678 .198 & .119 .888 & 7,14 \\
\hline Co740 & 9 & 72.910 & 1.178 .694 & 72.699 & 6,17 \\
\hline CB46-47 & 9 & 16.982 & 309.449 & 15.895 & 5,14 \\
\hline СB49-62 & 9 & 7.200 & 125.558 & 8.667 & 6,90 \\
\hline CB47-89 & 8 & 9.131 & 166.142 & 12.306 & 7,11 \\
\hline IAC52/326 & 6 & 6.850 & 111.937 & 7.905 & 7,06 \\
\hline IAC52/179 & 5 & 5.809 & 105.539 & 14.847 & 14,07 \\
\hline Co775 & 5 & 3.746 & 57.649 & 1.819 & 3,16 \\
\hline IAC $50 / 134$ & 4. & 15.735 & 290.309 & 25.857 & 8,91 \\
\hline CB36-24 & 4 & 14.800 & 252.269 & 16.090 & 6,38 \\
\hline CB56-155 & 4 & 11.050 & 205.459 & 16.363 & 7,96 \\
\hline CB56-86 & 4 & 1.704 & 25.882 & 2.267 & 8,76 \\
\hline
\end{tabular}

